\title{
The Upper Jurassic of Europe: its subdivision and correlation
}

\author{
Arnold Zeiss
}

In the last 40 years, the stratigraphy of the Upper Jurassic of Europe has received much attention and considerable revision; much of the impetus behind this endeavour has stemmed from the work of the International Subcommission on Jurassic Stratigraphy.

The Upper Jurassic Series consists of three stages, the Oxfordian, Kimmeridgian and Tithonian which are further subdivided into substages, zones and subzones, primarily on the basis of ammonites. Regional variations between the Mediterranean, Submediterranean and Subboreal provinces are discussed and correlation possibilities indicated. The durations of the Oxfordian, Kimmeridgian and Tithonian Stages are reported to have been 5.3, 3.4 and 6.5 Ma, respectively.

This review of the present status of Upper Jurassic stratigraphy aids identification of a number of problems of subdivision and definition of Upper Jurassic stages; in particular these include correlation of the base of the Kimmeridgian and the top of the Tithonian between Submediterranean and Subboreal Europe. Although still primarily based on ammonite stratigraphy, subdivision of the Upper Jurassic is increasingly being refined by the incorporation of other fossil groups; these include both megafossils, such as aptychi, belemnites, bivalves, gastropods, brachiopods, echinoderms, corals, sponges and vertebrates, and microfossils such as foraminifera, radiolaria, ciliata, ostracodes, dinoflagellates, calcareous nannofossils, charophyaceae, dasycladaceae, spores and pollen. Important future developments will depend on the detailed integration of these disparate biostratigraphic data and their precise combination with the abundant new data from sequence stratigraphy, utilising the high degree of stratigraphic resolution offered by certain groups of fossils. This article also contains some notes on the recent results of magnetostratigraphy and sequence chronostratigraphy.

Keywords: Europe, Upper Jurassic, Oxfordian, Kimmeridgian, Tithonian, Volgian, ammonite zonal and subzonal biostratigraphy and correlations, subdivision by non-ammonite fossil groups, chronometric data, magnetostratigraphy, sequence stratigraphy

Institut für Paläontologie der Universität Erlangen-Nürnberg, Loewenichstr. 28, D-91054 Erlangen, Germany. Present address: Albert Schweitzer Strasse 19, D-91080 Uttenreuth, Germany. E-mail: arnold.zeiss@t-online.de 


\section{Contents}

Subdivision and definition of stages: status and unsolved problems 78

The Upper Jurassic (Malm) Series 79

Boundaries of the Upper Jurassic Series

Lower boundary (Middle-Upper Jurassic Series boundary) 79

Upper boundary (Jurassic-Cretaceous System boundary) 80

Upper Jurassic stages - subdivision and correlation 81

Oxfordian

Lower boundary

Substages

Zones

Correlation

Chronometric data $\quad 85$

Kimmeridgian

Lower boundary

Additional remarks on Lower Kimmeridgian correlation 89

Substages

$\begin{array}{ll}\text { Zones } & 90\end{array}$

$\begin{array}{ll}\text { Correlation } & 91\end{array}$

$\begin{array}{ll}\text { Chronometric data } & 91\end{array}$

Tithonian and Volgian 991

Lower boundary $\quad 92$

Substages
Zones and Subzones

Zones and Subzones

Correlation $\quad 95$

Chronometric data

Biochronological importance of non-ammonite fossil groups: a review 96

Invertebrate megafossil groups 96

Cephalopods - other than ammonite conchs 96909 Aptychi $\quad 96$

$\begin{array}{lr}\text { Belemnites } & 96\end{array}$

$\begin{array}{lr}\text { Bivalves } & 97\end{array}$

$\begin{array}{ll}\text { Gastropods } & 97\end{array}$

$\begin{array}{ll}\text { Brachiopods } & 97\end{array}$

$\begin{array}{lr}\text { Echinoderms } & 97\end{array}$

\begin{tabular}{l} 
Corals (scleractinians) \\
\hline
\end{tabular}

Sponges

Vertebrate megafossils

Invertebrate microfossils 98

$\begin{array}{ll}\text { Foraminifera } & 98\end{array}$

$\begin{array}{lr}\text { Radiolaria } & 98\end{array}$

Ciliata

Ostracodes

Plant microfossils

Dinoflagellata 99

Calcareous nannofossils (coccoliths, nannolith groups) 99

$\begin{array}{lr}\text { Charophyaceae } & 100\end{array}$

$\begin{array}{lr}\text { Dasycladaceae } & 100\end{array}$

$\begin{array}{ll}\text { Spores and pollen } & 100\end{array}$

Magnetostratigraphy 100

Sequence chronostratigraphy 100

Acknowledgements $\quad 101$

References $\quad 101$ 
The term 'Upper Jurassic' ('Oberer Jura') was introduced by von Buch (1839). Arkell (1956) revived this name with only minor changes in its chronostratigraphic content. The term 'Upper Jurassic' in the sense of Arkell (1956) was accepted by the First and Second 'Colloque du Jurassique' at Luxembourg in 1962 and 1967; only the stage name 'Purbeckian' was eliminated, as it was considered to characterise merely a distinct lithofacies. This usage was followed by the five subsequent International Symposia on Jurassic Stratigraphy at Erlangen in 1984, Lisbon in 1987, Poitiers in 1991, Mendoza in 1994 and Vancouver in 1998. Focus on the formal stratigraphic subdivision of the Jurassic, and the Upper Jurassic in particular, is reflected in the series of key meetings since the early 1960's (Table 1).

The term 'Malm' was included in the recommendations of the First Luxembourg Colloquium in 1962 as an alternative term for the 'Upper Jurassic' (Maubeuge 1964). Although this term, like the term 'Tithonian' (see below), is not based on a geographical site, it has been widely used since its introduction by Oppel (1858, 1865). Referring to the Tithonian stage, Arkell (1956, p. 8) wrote: "it is too late to abolish it after a hundred years of continuous use"; this also applies to the term 'Malm'. It is important to note that both 'Upper Jurassic' and 'Malm' are chronostratigraphic terms; the latter, in particular, has frequently been used in a lithostratigraphic sense by some authors.

At the First Colloquium in Luxembourg in 1962, a subdivision of the Jurassic System into stages was proposed, the basic framework of which has survived to the present day. The stages were defined by their lower and upper ammonite zones. The recommendations of the First Colloquium (Maubeuge 1964) were thus a landmark in the history of international agreements concerning the subdivision of the Jurassic System into series and stages.

After a period of discussion following the publication of the resolutions of the Luxembourg Colloquia (Maubeuge 1964, 1970), these proposals have been accepted

Table 1. Key events in Upper Jurassic stratigraphy since 1960

\begin{tabular}{|c|c|c|c|}
\hline Date & Place & Event & Reference \\
\hline 1962 & Luxembourg & Colloque du Jurassique à Luxembourg & Maubeuge 1964 \\
\hline 1965 & Sofia & VII Congress, Carpatho-Balkan Geological Association & CBGA 1965 \\
\hline 1967 & Luxembourg & Colloque du Jurassique à Luxembourg & Maubeuge 1970; BRGM 1974 \\
\hline 1967 & Moscow & International Symposium on Upper Jurassic stratigraphy & ANSSR 1974 \\
\hline 1969 & London & William Smith Symposium on Jurassic geology & \\
\hline 1969 & Budapest & Colloque du Jurassique Méditerranéen & Végh-Neubrandt 1971 \\
\hline 1973 & Neuchâtel & Colloque sur la limite Jurassique-Cretacé, Lyon & BRGM 1975 \\
\hline 1975 & Sofia & International Symposium on the Jurassic-Cretaceous boundary in Bulgaria & Nikolov \& Sapunov 1977 \\
\hline 1977 & Stuttgart & $\begin{array}{l}\text { International Field Meeting on the Jurassic System of southern Germany - this meeting } \\
\text { initiated the reorganisation of the International Subcommission on Jurassic Stratigraphy }\end{array}$ & Zeiss 1977; Ziegler 1977 \\
\hline 1979 & Novosibirsk & International Colloquium on the Upper Jurassic and the Jurassic-Cretaceous boundary & Saks 1979 \\
\hline 1984 & Erlangen & International Symposium on Jurassic stratigraphy & Michelsen \& Zeiss 1984 \\
\hline 1984 & Sümeg & Meeting of the Working Group for the Jurassic-Cretaceous boundary & Fülöp 1986 \\
\hline 1987 & Lisbon & 2nd International Symposium on Jurassic stratigraphy & Rocha \& Soares 1988 \\
\hline 1987 & & $\begin{array}{l}\text { International Field Meeting on Jurassic-Cretaceous boundary problems at } \\
\text { the Northern Caucasus }\end{array}$ & Menner 1990 \\
\hline 1988 & Zaragoza & 1st Oxfordian Working Group Meeting, Zaragoza - Iberian Chain & Meléndez 1990 \\
\hline 1990 & Basel & 2nd Oxfordian Working Group Meeting, Basel and Jura range of northern Switzerland & Gygi 1990b \\
\hline 1991 & Poitiers & 3rd International Symposium of Jurassic stratigraphy & Cariou \& Hantzpergue 1994 \\
\hline 1992 & Warsaw & Joint Meeting of the Oxfordian and Kimmeridgian Working Groups & Atrops et al. 1993a \\
\hline 1993 & London & W. J. Arkell Symposium of Jurassic geology & Taylor 1996 \\
\hline 1994 & Mendoza & 4th International Symposium on Jurassic stratigraphy & Riccardi 1996 \\
\hline 1994 & Lyon & $\begin{array}{l}\text { 4th Oxfordian and Kimmeridgian Working Groups Meeting, Lyon and } \\
\text { South-Eastern France Basin }\end{array}$ & Atrops \& Meléndez 1994a \\
\hline 1997 & Warsaw & Oxfordian (Jurassic) Meeting in Poland & Glowniak et al. 1997 \\
\hline 1998 & Vancouver & 5th International Symposium on the Jurassic System & Pálfy 1998, Hall \& Smith 2000 \\
\hline
\end{tabular}


worldwide, the only exception being that in the former Soviet Union the Callovian has been considered to belong to the Upper Jurassic (see Krymholts et al. 1988), while in the rest of the world the Callovian is included in the Middle Jurassic. However, following a decision by the Interdepartmental Stratigraphic Commitee in 1989, the Callovian is also now considered in Russia to belong to the Middle Jurassic (Zhamojda 1991).

According to the most recent estimates, the Late Jurassic had a duration of a little more than 15 million years according to Gradstein et al. (1994, 1995; Ogg 1995), or 12 million years (+5.6/-7.3) according to Pálfy et al. (1998). The data of Gradstein et al. (1995) have been used in Figures 2, 4 and 5 of this paper; on this basis each of the three Upper Jurassic stages has an average length of 5 million years, while zones and subzones have approximate durations of 700000 and 300000 years, respectively. Each subzone comprises at least three horizons, each of which has an approximate duration of 100000 years.

\section{Subdivision and definition of stages: status and unsolved problems}

On the basis of the recommendations of the First Luxembourg Colloquium (Maubeuge 1964), the Upper Jurassic Series was subdivided into four stages for the Boreal and Subboreal regions: Oxfordian, Kimmeridgian (sensu anglico), Portlandian (sensu anglico) and Volgian, and three for the Submediterranean and Mediterranean regions: Oxfordian, Kimmeridgian (sensu gallico equivalent to 'Crussolian') and Tithonian (equivalent to 'Danubian' and 'Ardescian'). In the following decades, there has been much confusion as the Kimmeridgian and Portlandian Stages have often been used differently in different parts of Europe.

In 1990, a formal vote of the International Subcommission on Jurassic Stratigraphy (ISJS) led to the decision to use stages with approximately the same vertical age ranges and uniform names in both regions: Kimmeridgian (sensu gallico) and Tithonian (Zeiss 1991a). With regard to the still unresolved correlation problems between the Boreal and Mediterranean provinces, it was agreed that the Volgian can be used as an alternative stage for the Tithonian in Subboreal and Boreal regions (Fig. 1).

The main problem which remained to be solved was the definition of the lower boundary of each stage. To date, no stage has a type locality and a defined lower boundary (global stratotype section and point, or GSSP) formally accepted by the International Commission on Stratigraphy (ICS). There are of course a lot of proposals, but they have not been validated according to the guidelines and rules of the ICS (Cowie et al. 1986; Remane et al. 1996).

The most intractable problems are to find isochronous levels in Submediterranean (and Mediterranean) and Subboreal (and Boreal) Europe for the lower boundary of the Kimmeridgian Stage and for the upper boundary of the Tithonian (Volgian) Stage. As the former is of particular significance for Upper Jurassic subdivision and correlation, it will be treated here in some detail (see below).

Other problems are the unification of the differing subdivisions of stages into substages, correlation of the zones of each stage between the different areas of Europe and the development of better correlation charts from the Boreal regions to the Mediterranean areas. Provisional correlation charts on a zonal and subzonal level for each stage of the European Upper Jurassic are presented here (see Figs 2-5). Zones and subzones are used here as chronozones following the International Stratigraphic Guide (Salvador 1994); originally, many of them were defined as biozones whereas others were used as standard zones, standard chronozones or biochronological standard zones, i.e. only the base is defined while the top is defined by the base of the next overlying unit (Callomon 1965, 1984a, 1994). Problems arise, however, due to inconsistent usage of the term 'standard zone'. In Northwest Europe, standard zones are mostly used following the concept of Callomon (1994), whereas in central and southern Europe, standard zones are often synonymous with biostratigraphic zones for use in biochronology (Cariou \& Hantzperque 1997). It is often difficult, therefore, to determine in which meaning 'standard zones' are used. The problems encountered in moving from biostratigraphic field data to biochronological interpretations have been discussed recently by Remane (1991).

The term biochronological zone is now used by many authors instead of chronostratigraphic zone, if the zone is based on fossil data. As the ultimate subdivision of biochronology, French authors use the term 'biohorizon' (e.g. Enay 1997); their concept is therefore 'sensiblement different' from the pure biostratigraphic horizon concept of J.H. Callomon (Dommergues 1997).

No attempt has been made here to correlate ammonite faunal horizons due to the variable nature of the published research on the Upper Jurassic in the various sedimentary basins of Europe. Where necessary, however, correlations of horizons are discussed in the text. 
For an example of such horizon correlations, the reader is referred to the work of Callomon (1984c) on the Upper Jurassic of North America (this study also covers the European Amoeboceras subdivision). Although attempts have been made to generalise horizons for the whole 'domaine tethysien' and 'domaine boréal' (Cariou et al. 1997; Hantzperque et al. 1997), these appear premature and of little practical use, given the present state of knowledge.

In Europe, subdivisions down to the level of ammonite faunal horizons have been proposed for several sedimentary basins. Such studies include that of the Upper Jurassic of East Greenland by Callomon \& Birkelund (1980, 1982; Birkelund \& Callomon 1985), the Lower Kimmeridgian of southern England by Birkelund et al. (1983), the Kimmeridgian of Spitsbergen by Wierzbowski (1989), the Kimmeridgian of the Barents Sea by Wierzbowski \& Smelror (1993), the lowermost Oxfordian of northern France by Vidier et al. (1993), the Upper Oxfordian, Kimmeridgian and Lower Tithonian of western France by Hantzperque (1989), the lowermost Oxfordian of south-east France by Fortwengler \& Marchand (1994b), the Lower Kimmeridgian of south-east France by Atrops (1982), the Upper Oxfordian, Upper Kimmeridgian and Lower Tithonian of south-west Germany by Schweigert (1994, 1995a, b, 1996a, b; Schweigert \& Callomon 1997), the OxfordianKimmeridgian of Poland (Matyja \& Wierzbowski 1997), the Middle Volgian of central Poland (Kutek 1994) and the Oxfordian of north-east Spain by Cariou et al. (1991a) and Meléndez \& Fontana (1993).

The 'faunal horizon' approach clearly represents a method for increasing precision in correlation and dating in the future, when the data from the various sedimentary basins reach the necessary standard. It is already proving useful in deciphering the history of basin deposits at a resolution that was hitherto impossible; such data, in particular, allow us to date events more precisely and to determine the 'completeness' of the sedimentary record i.e. to identify accurately the position and duration of hiatuses. A prerequisite is, however, that it is possible to reconstruct the complete succession of faunal horizons by correlating individual local successions.

In this context, it is worth mentioning that the methods of Jurassic stratigraphy and high-resolution geochronology have been discussed in detail by Callomon (1984a, b, 1994, 1995), Page (1995), Corna et al. (1997), Blau (1998) and Blau \& Meister (2000); formal aspects were covered by Remane (1996).

\section{The Upper Jurassic (Malm) Series (Fig. 1)}

In this paper, subdivision and correlation of the Upper Jurassic Series have been carried out mainly using ammonites. Other fossil groups are reviewed briefly, however, with request to their biochronologic resolution and correlation potential. Many papers have been published on Upper Jurassic ammonites and their chronostratigraphic resolution (see detailed discussion below). For a broad overview, the reader is referred to the papers of Cariou et al. (1997), Geyssant (1997) and Hantzpergue et al. (1997) for western Europe and the Mediterranean. Other important, partly regional compilations and revisions have been published by Sapunov (1979), Donovan et al. (1981), Krymholts et al. (1988), Malinowska et al. (1988), Enay et al. (1994) and Schlegelmilch (1994).

\section{Boundaries of the Upper Jurassic Series}

\section{Lower boundary}

(Middle-Upper Jurassic Series boundary)

The lower boundary of the Oxfordian Stage is rather well-defined by ammonite zones and subzones and only requires more precise definition with respect to the lowermost faunal horizon, which then would characterise the beginning of the lowermost subzone (and zone) of the stage. Furthermore, it appears that the lower boundary is approximately (on a subzonal level) the same in Boreal and Mediterranean areas. Once the type faunal horizon has been chosen, then the problem of the type locality for the boundary will also have been solved. At present, this boundary lies in France between the uppermost horizon of the Quenstedtoceras lamberti Zone of the Upper Callovian Substage (the Cardioceras paucicostatum horizon) and the lowermost horizon of the Q. mariae Zone; this was first named in France after Peltoceratoides elisabethae (Fortwengler \& Marchand 1994a), but afterwards was changed to Hecticoceras (Brightia) thuouxense (Fortwengler \& Marchand 1994b, c), a species described only recently (Fortwengler et al. 1997). In Dorset, however, Cardioceras cf. woodhamense and C. woodhamense are found in the lowermost levels of the $Q$. mariae Zone (Callomon \& Cope 1996), whereas in north-west France, C. woodhamense has been collected only in the third horizon of the Q. mariae Zone (Vidier et al. 1993). In south-east France, this horizon is only recognised tentatively. These different faunal horizons all lie 


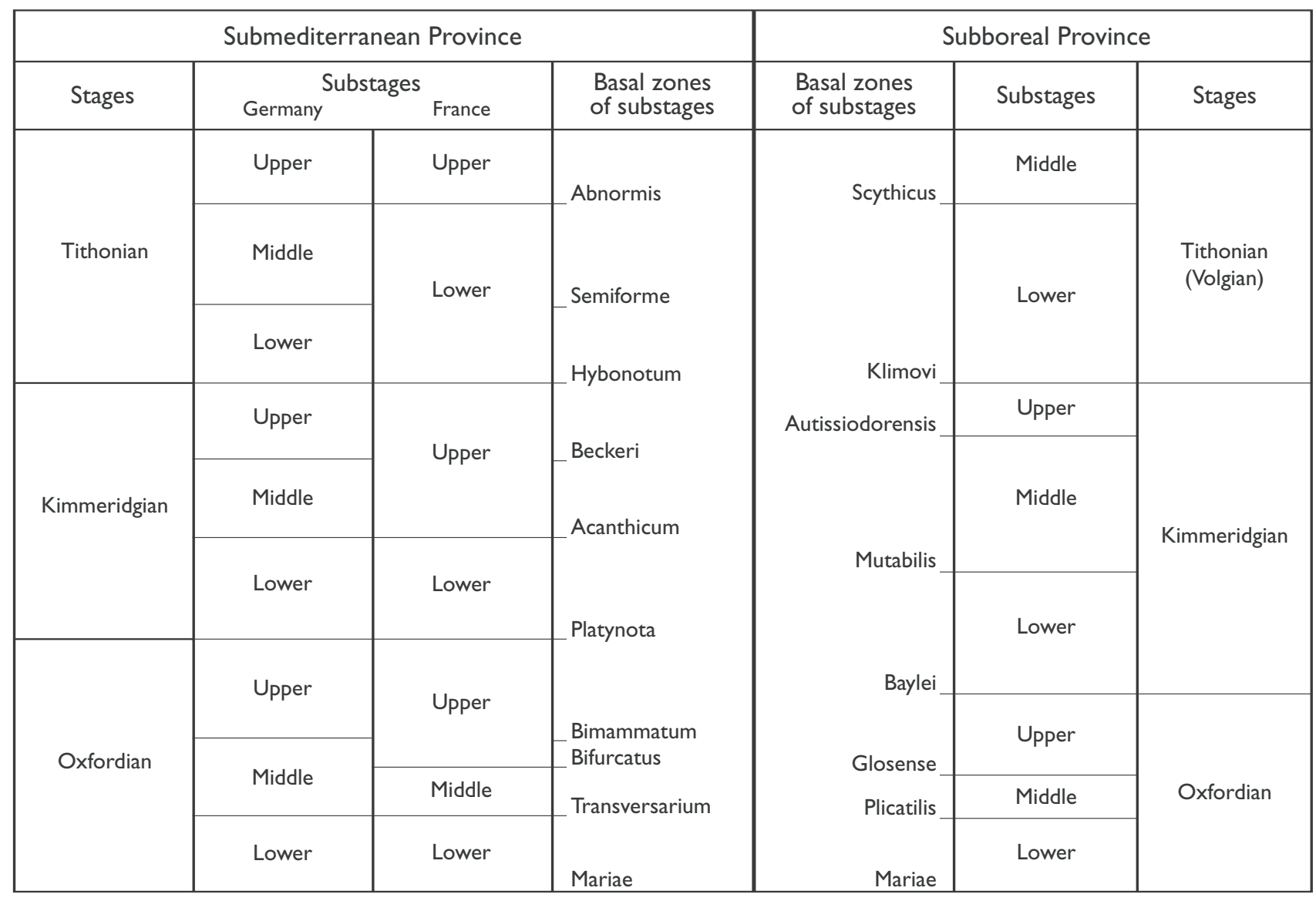

Fig. 1. Subdivision of the Upper Jurassic Series of Europe into stages, substages and zones. Substage usage varies in the literature, dependent on author; those indicated are only examples.

in the Cardioceras scarburgense Subzone, the lower subzone of the $Q$. mariae Zone, so that the age difference of these horizons (if any) should not be too large. A vote by the Callovian/Oxfordian Boundary Working Group in 1995 resulted in a preference for a type locality in south-east France, with the consequence that the Oxfordian would begin with the H.(B.) thuouxense horizon (see above), but a final decision was not taken (Meléndez 1995; Meléndez et al. 1998).

\section{Upper boundary}

(Jurassic-Cretaceous System boundary)

In accordance with the decision of the ISJS (see above), there are two alternative stages for the uppermost part of the Jurassic System: Tithonian and Volgian. As they differ in duration, the boundary may be drawn at two different levels, i.e. there are two variants of the Jurassic-Cretaceous boundary. Accordingly, the mem- bers of the former Jurassic-Cretaceous Boundary Working Group agreed to work provisionally with two boundaries (Remane 1986; Remane et al. 1986; Zeiss 1986).

1. In Mediterranean and Submediterranean Europe, the boundary is placed between the top of the Tithonian Stage (top of Durangites vulgaris Zone and/or of Calpionellid Zone A) and the base of the Berriasian Stage (base of Berriasella jacobi Zone s.l. (= Berriasella jacobi and Pseudosubplanites grandis Subzones or Pseudosubplanites euxinus Zone) and/or base of Calpionellid Zone B).

2. In Subboreal and Boreal Europe, the boundary lies between the Upper Volgian (top of Craspedites nodiger or Chetaites chetae Zone) and the Ryazanian or 'Boreal Berriasian' (base of Chetaites sibericus, Rjasanites rjasanensis or Runctonia runctoni Zone) (Rawson et al. 1978; Kejsi et al. 1988; Sey \& Kalacheva 1993a). 
In the first case, the type locality should be best selected in south-eastern France, where the Ardescian Substage (Upper Tithonian) and the Berriasian Stage were originally described. Subsequent studies have revealed that the sequences are not complete at the base, however, so that it has been suggested that the best sections illustrating the Jurassic-Cretaceous boundary beds and their fauna are situated in southern Spain (Enay \& Geyssant 1975; Tavera 1985; Tavera et al. 1994; Enay et al. 1998a, b).

In the second case, the boundary should correspond to the base of the Berriasella boissieri Zone in the Mediterranean area. Thus, the Upper Volgian Substage corresponds to the Lower Berriasian (Zeiss 1974, 1979, 1983, 1986; Rawson et al. 1978; Hoedemaker 1990; Sey \& Kalacheva 1993a; W.A. Wimbledon in: Callomon \& Cope 1996), and is not equivalent to the Upper Tithonian as Mesezhnikov (1988) and other authors have assumed.

In a recent review of the Berriasian Stage, Hoedemaker (1994) stated that the Jurassic-Cretaceous boundary is typically placed at one of two different levels, either at the base or at the top of the Jacobi Chronozone: "Investigators of Jurassic stratigraphy prefer the lower of these two boundaries, investigators of the Cretaceous stratigraphy the upper" (Hoedemaker 1994, p. 12).

At the same time, there has also been an attempt to trace the Jurassic-Cretaceous boundary based on geomagnetic anomalies from the Tethys to southern England (Ogg et al. 1994). In the Tethyan-Atlantic faunal realm, the top of magnetic polarity reversal M19r approximately coincides with the Tithonian-Berriasian boundary in the Mediterranean area. This reversal is difficult to place precisely in England, but it seems to be situated in the lowermost Purbeck beds. If so, it would demonstrate once again that the 'Upper Volgian' (Casey 1973) or 'Upper Portlandian' of England (Wimbledon 1980), i.e. the zonal sequence Subcraspedites primitivus - Subcraspedites lamplughi, overlaps with the Lower Berriasian.

Wimbledon (1980) also included the 'Upper Volgian' zones of Casey (1973) in the 'Portlandian' of Britain, thus extending the stage upwards by three further zones (termed here 'Upper Portlandian'). In a recent compilation chart, W.A. Wimbledon (in: Callomon \& Cope 1996) correlated these 'Upper Portlandian' zones and the Upper Volgian zones of the Russian platform with parts of the Lower Berriasian.

In Poland, the Jurassic-Cretaceous boundary has been traced by joint studies of ostracodes and ammonites (Marek et al. 1989) whereby the Upper Tithonian and the lower part of the Lower Berriasian could be recognised as well as the Upper Berriasian (= 'Ryazanian').
In a recent paper (Marek \& Shulgina 1996), the ammonites of the Berriasian (Ryazanian) were considered to belong to the interval upper occitanica - lower boissieri Zones.

In a recent development, the Interdepartmental Stratigraphic Committee of Russia (ISC) approved the following resolutions of its commissions on the Jurassic and Cretaceous Systems (Rostovtsev \& Prozorovskiy 1997, p. 48).

"1. To draw the Jurassic-Cretaceous boundary in the Boreal Realm between the middle and upper substages of the Volgian, and not ...... as ...... earlier adopted in Russia (1978). This boundary mainly corresponds to the Tithonian/Berriasian boundary in Tethyan realm (Colloque Lyon-Neuchâtel, 1975). Correspondingly, the Lower Volgian in the whole correlated with the Lower and Middle Tithonian; the Middle Volgian, with the Upper Tithonian; the Upper Volgian, with two lower zones of the Berriasian (Jacobi/Grandis and Occitanica).

2. To transfer the Volgian Stage in its former range to the category of regional stratigraphic units (regional stage). To distinguish as chronostratigraphic units in the boundary part of the Jurassic and Cretaceous scale of Russia only Tithonian and Berriasian."

These resolutions, which were precipitated by the work of Sey \& Kalacheva (1993a), confirmed the earlier opinions of many authors concerning Upper Jurassic/Lower Cretaceous correlations.

It is clear that general consensus has not yet been reached; it is assumed, however, that the present Tithonian-Berriasian boundary is not suitable for global correlation. It may be preferable, therefore, to return to an old proposal: to define the Jurassic-Cretaceous boundary at the base of the $B$. boissieri Zone, where many guide fossils of different groups are available for correlation. Recent studies in the Caucasus area by Remane (1997) are supportive of this proposal.

\section{Upper Jurassic stages - subdivision and correlation}

\section{Oxfordian (Figs 2, 3)}

The Colloquium at Luxembourg in 1962 (Maubeuge 1964, p. 85) came to the resolution "...... that it seemed necessary to return to the original sense of this stage 


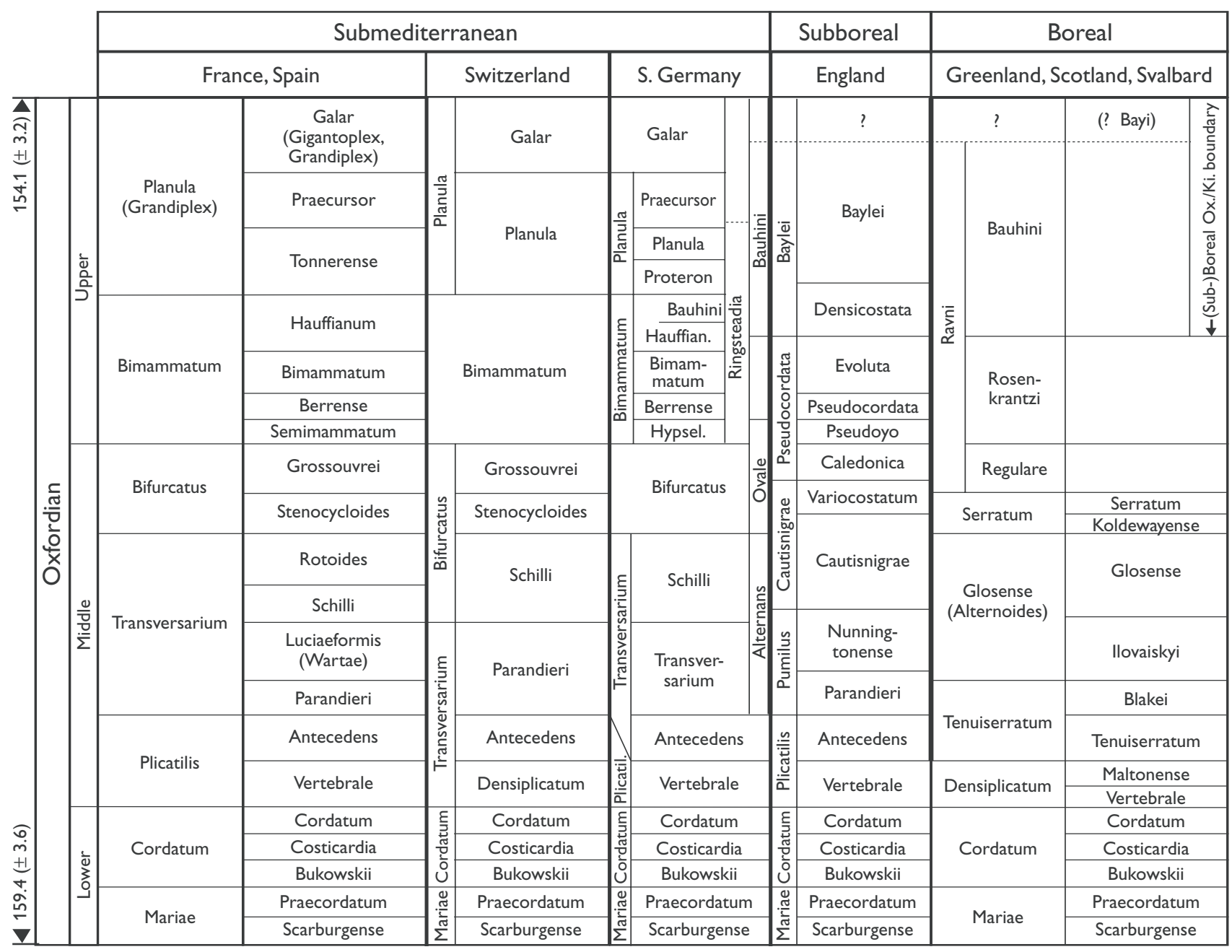

Fig. 2. A tentative correlation chart for the Oxfordian Stage in Europe (thick lines indicate periods during which correlation is difficult). Modified after Zeiss (1984), Mesezhnikov (1988), Cariou et al. (1991b), Wright (1996a, b), Matyja \& Wierzbowski (1997, 1998), Schweigert \& Callomon (1997) and Gygi (2000a, b).

[the Oxfordian] as defined by A. d'Orbigny and given precision by W.J. Arkell (1956)". The 'base' was indicated to be the 'Zone of Quenstedtoceras mariae' and the 'top' the 'Zone of Ringsteadia pseudocordata (= Zone of Idoceras planula), (= Zone of Epipeltoceras bimammatum)'. It was recommended that other stage and substage names then still in use, e.g. the Argovian (Marcou 1848), Rauracien (Greppin 1867), Sequanian (Marcou 1848) and the Lusitanien (Choffat 1885; Haug 1910) should be abandoned. These stages had been interpreted in different ways so that continued usage would have created only more confusion. Subsequent studies (e.g. Enay 1980a; Gygi \& Persoz 1986; Enay et al. 1988) demonstrated the validity of this resolution.

\section{Lower boundary}

See discussion above.

\section{Substages}

Although the Oxfordian has been subdivided into three substages, Lower, Middle and Upper Oxfordian, full agreement has not been reached on the zonal content of these substages and the position of their boundaries (Callomon 1988, 1990, fig. 10; Meléndez \& Fontana 1993, fig. 5; Wright 1996a). The subdivision is thus essentially informal but the substages are capitalised in 


\begin{tabular}{|c|c|c|c|c|c|c|c|}
\hline \multicolumn{2}{|c|}{$\begin{array}{l}\text { Submediterranean } \\
\text { Standard } \\
\text { (Cariou et al. 1991b) }\end{array}$} & \multicolumn{2}{|c|}{$\begin{array}{c}\text { Spain - North Africa } \\
\text { (Sequeiros 1974; } \\
\text { Cariou et al. 1991b) }\end{array}$} & \multicolumn{3}{|c|}{$\begin{array}{c}\text { Poland } \\
\text { (Tarkowski 1990; } \\
\text { Matyja \& Glowniak 1994) }\end{array}$} & $\begin{array}{c}\text { Bulgaria } \\
\text { (Sapunov 1976) }\end{array}$ \\
\hline \multirow{4}{*}{$\begin{array}{c}\text { Trans- } \\
\text { versarium }\end{array}$} & Rotoides & \multirow{4}{*}{ Riazi } & & \multirow{5}{*}{$\begin{array}{c}\text { Trans- } \\
\text { versarium }\end{array}$} & \multirow{4}{*}{\multicolumn{2}{|c|}{ Wartae }} & \multirow{4}{*}{ Riazi } \\
\hline & Schilli & & & & & & \\
\hline & Luciaeformis & & & & & & \\
\hline & Parandieri & & & & & & \\
\hline \multirow{3}{*}{ Plicatilis } & Antecedens & Antecedens & & & \multicolumn{2}{|c|}{ Antecedens } & Antecedens \\
\hline & \multirow{2}{*}{$\begin{array}{c}\text { Vertebrale } \\
\text { (Tenuicostatum) }\end{array}$} & \multirow{3}{*}{ Paturattensis } & \multirow[t]{2}{*}{ Magnouatius } & \multirow[t]{2}{*}{ Plicatilis } & \multicolumn{2}{|c|}{ Promiscuus } & \multirow{2}{*}{ Episcopalis } \\
\hline & & & & & Patu- & Helenae & \\
\hline \multirow{4}{*}{ Cordatum } & Cordatum & & Paturattensis & \multirow{2}{*}{ Paturattensis } & sis & & \multirow{4}{*}{ Renggeri } \\
\hline & & \multirow{3}{*}{$\begin{array}{c}\text { Claro- } \\
\text { montanus }\end{array}$} & & & \multicolumn{2}{|c|}{ Oculatum } & \\
\hline & Costicardia & & Mazuricus & \multirow{4}{*}{ Minax } & \multirow{2}{*}{\multicolumn{2}{|c|}{ Baccatum }} & \\
\hline & Bukowskii & & $\begin{array}{l}\text { Claro- } \\
\text { montanus }\end{array}$ & & & & \\
\hline \multirow{2}{*}{ Mariae } & Praecordatum & & & & \multirow{2}{*}{\multicolumn{2}{|c|}{ Spixi }} & \multirow{2}{*}{ Athletoides } \\
\hline & Scarburgense & & & & & & \\
\hline
\end{tabular}

Fig. 3. A tentative correlation chart for some alternative subdivisions of parts of the Oxfordian Stage in Mediterranean and Submediterranean Europe.

this paper, following common usage. An example of the ongoing debate is the inclusion of the D. bifurcatus Zone in the Middle or Upper Oxfordian; this zone was introduced by Enay (1966) as the upper subzone of the G. transversarium Zone but was later considered as the lowermost zone of the Upper Oxfordian (Cariou et al. 1971). Preference is given here to a subdivision in which the D. bifurcatus Zone is included in the Middle Oxfordian (Fig. 1) as has also been proposed by Meléndez (1989), Cariou \& Meléndez (1990), Cariou et al. (1991a) and Gygi (2000a) although not followed by Cariou et al. (1991b, 1997).

While the lower and middle substages have the same lower boundaries in Submediterranean and Subboreal Europe, the position of the lower boundary of the upper substage differs. In Boreal Europe, it has been drawn at three different levels (Wright 1996a, fig. 6). The solution to draw it at the base of the A. glosense Zone is well-known (Sykes \& Callomon 1979; Wright 1980); it would correspond to the base of the P. luciaeformis Subzone in the G. transversarium Zone, i.e. the boundary would be drawn around one and a half zones deeper than in the Submediterranean subdivision. It seems preferable to draw the boundary at the lower boundary of the $A$. rosenkrantzi Zone, corresponding approximately to the lower boundary of the Upper Oxfordian both in Submediterranean Europe (base of E. bimammatum Zone) and in Subboreal Europe (base of $R$. pseudocordata Zone), although the latter lies somewhat deeper (Matyja \& Wierzbowski 1997, fig. 4).

Additional literature references pertinent to the subdivision of the Oxfordian Stage are Enay $(1963,1966)$, Zeiss (1966), Sequeiros (1974), Sapunov (1976), Gygi (1977, 1986, 1990a, 2000a, b, c), Wierzbowski (1978), Enay \& Meléndez (1984), A. Zeiss (in: Enay \& Meléndez 1984), Cariou \& Meléndez (1990), Malinowska (1991), Meléndez \& Fontana (1993), Schweigert (1995a, b), Fözy \& Meléndez (1996), Matyja \& Wierzbowski (1997, 1998), Groiss et al. (2000) and Schweigert \& Callomon (1997) for the Submediterranean and Mediterranean provinces, and Sykes \& Callomon (1979), Wright (1980, 1996a, b) and Mesezhnikov (1988) for the Subboreal and Boreal provinces. Mönning \& Bertling (1995), Mönning (1998) and Gramann et al. (1997) have presented interesting and useful reviews of the ammonite succession in northern Germany. 


\section{Zones}

The zonal and subzonal subdivision of the Lower Oxfordian Substage was established by Arkell (1941) using Quenstedtoceras mariae and Cardioceras cordatum as index species; it can be used over large areas of northern and central Europe (Fig. 1) and is also applicable in the Dauphinois basin of south-east France as recently demonstrated by Fortwengler \& Marchand (1994a; Fortwengler et al. 1995).

In southern Europe, a variety of subdivisions exist; at least three distinct subdivisions testify to the difficulties in erecting a generally accepted zonal scheme if cardioceratids are missing. In such cases, peltoceratids (Peltomorphites, Peltoceratoides and Parawedekindia), oppeliids (Taramelliceras, Popanites and Creniceras) and perisphinctids (Otosphinctes, Perisphinctes, Prososphinctes and Properisphinctes) are important guide fossils (see Fig. 3), e.g. Taramelliceras minax, T. spixi, T. baccatum, T. oculatum, Popanites paturattensis in Poland (Tarkowski 1990), Peltomorphites athletoides and Creniceras renggeri in Bulgaria (Sapunov 1976), and Prososphinctes mazuricus and P. claromontanus in Spain (Aurell et al. 1990).

From the base of the Middle Oxfordian, perisphinctids and peltoceratids become the dominant ammonite groups with respect to index fossils at the substage level in the Submediterranean and Subboreal provinces. The first aulacostephanids (Decipia) also appear at this level. The Perisphinctes plicatilis, Gregoryceras transversarium and Dichotomoceras bifurcatum Zones make up the Middle Oxfordian Substage in the Submediterranean area, the Perisphinctes plicatilis, P. pumilum and $P$. cautisnigrae Zones are representative of the Subboreal province. Boreal indexes are Cardioceras tenuicostatum and C. tenuiserratum, Amoeboceras glosense and A. serratum. The correlation between Subboreal perisphinctid and amoeboceratid zones was well demonstrated by Wright (1996b).

There is a difference in the usage of the P. plicatilis and G. transversarium Zones in Submediterranean Europe. Although Gygi \& Marchand (1982) replaced the basal $C$. vertebrale Subzone with the $C$. densiplicatum Zone and included the $P$. antecedens Subzone in the $G$. transversarium Zone, subsequent authors have not followed the arguments of these authors and have continued to use the P. plicatilis Zone in the sense of Cariou et al. (1991a, b), i.e. with C. vertebrale and P. antecedens Subzones (e.g. Meléndez \& Fontana 1993, fig. 4; Cariou et al. 1997). Cariou et al. (1991a) defined the G. transversarium Zone to contain the P. parandieri, P. luciae- formis, L. schilli and $P$. rotoides Subzones. In a more recent publication, Gygi (1995) included in the lower part of the $G$. transversarium Zone not only the $P$. antecedens Subzone but also the $C$. densiplicatum Subzone i.e. the whole P. plicatilis Zone (following the original usage of Oppel \& Waagen 1866; R.A. Gygi, personal communication 1997). In further contributions to the Upper Jurassic of Switzerland (Gygi 2000b, c), the $G$. transversarium Zone is subdivided into the $C$. densiplicatum, P. antecedens, and P. luciaeformis Subzones; the overlying $D$. bifurcatus Zone contains in its lower part the L. schilli Subzone, which is considered in Spain and France to represent the upper part of the G. transversarium Zone (see above). The main reason for these differences is the occurrence of $L$. schilli in Switzerland above the vertical range of $G$. transversarium

The Upper Oxfordian Substage in Submediterranean Europe comprises the Epipeltoceras bimammatum, Idoceras planula and Sutneria galar Zones. Considering the new correlations of Wright (1996a), Matyja \& Wierzbowski (1997) and Cariou et al. (1997), Ringsteadia pseudocordata would be the corresponding index fossil for the Subboreal province, whereas Amoeboceras rosenkrantzi iwould be the index fossil for Boreal Europe.

The Amoeboceras serratum Zone of Malinowska (1991) contains Epipeltoceras (ubligi group) and Ringsteadia salfeldithus indicating, at least partly, equivalence with the lower E. bimammatum Zone ( $E$. hypselum Subzone); this demonstrates that the A. serratum Zone of this author is younger in age than the A. serratum Zone of Sykes \& Callomon (1979). The $A$. regulare Subzone of Malinowska (1991) seems to represent the upper E. bimammatum and perhaps the lowermost I. planula Zones, while the A. lineatum Subzone apparently corresponds to the rest of the I. planula Zone and the $S$. galar Zone.

The most difficult problems associated with these Upper Oxfordian zones concern their correlation in the Subboreal and Submediterranean schemes; this aspect is discussed in detail below. Some minor problems may be caused by the different hierarchical status of zones and subzones in the Subboreal and Boreal provinces. For example, Atrops et al. (1993b) recognised the $A$. regulare, $A$. rosenkrantzi and $A$. baubini Zones, whereas Malinowska (1991) subdivided the $R$. pseudocordata Zone into the $A$. regulare and $A$. lineatum Subzones or, in Boreal Europe, into the $A$. regulare and $A$. rosenkrantzi Subzones. However, comparing the correlation chart of Malinowska (1991, table 3) with that of Matyja \& Wierzbowski (1997, fig. 3), it becomes evi- 
dent that the P. pseudocordata Zone of Malinowska corresponds only to the upper part of the A. regulare, the $A$. rosenkrantzi and the $P$. baylei Zones.

Another example is the variable status of $A$. baubini as an index species. There is the $A$. baubini horizon in the upper E. bimammatum zone equivalent to the $P$. densicostata horizon (Schweigert \& Callomon 1997), the $A$. baubini Subzone of the $A$. rosenkrantzi Zone (Sykes \& Callomon 1979; Cariou et al. 1997), equivalent to the P. baylei Zone of Birkelund \& Callomon (1985), and the A. baubini Zone. Although initially equivalent to the $P$. densicostata horizon (Wierzbowski \& Smelror 1993), the A. baubini Zone was expanded by Matyja \& Wierzbowski $(1997,1998)$ to correlate with the uppermost $P$. pseudocordata Zone and nearly the whole P. baylei Zone on the one hand and with the whole I. planula Zone and uppermost E. bimammatum Zone on the other; a little more restricted was the A. baubini Zone of Schweigert \& Callomon (1997), who excluded the $S$. galar Subzone of the I. planula Zone (see below).

\section{Correlation}

There have been many proposals and attempts to correlate the zonal subdivisions of the Oxfordian of Mediterranean, Submediterranean, Subboreal and Boreal areas of Europe; the most important ones have been already discussed in the text above (see Figs 2, 3). Further informative compilations have been presented by Enay \& Meléndez (1984), Mesezhnikov (1988), Cariou et al. (1991a, b; 1997), Malinowska (1991), Aleynikov \& Meledina (1993), Meléndez \& Fontana (1993), Schweigert (1995b), Wright (1996a, b) and Matyja \& Wierzbowski (1997). In short, correlation within the Lower Oxfordian is possible over wide regions of Boreal, Subboreal and Submediterranean Europe, but becomes difficult on approaching the Mediterranean area.

At the base of the Middle Oxfordian, ammonites of the Perisphinctes plicatilis Zone provide the last possibility for long-distance correlation. Higher up in the Middle Oxfordian, zonal correlations become more and more difficult, best illustrated by the charts of J.H. Callomon (in: Wright 1980), Enay \& Meléndez (1984) and Cariou et al. (1991b; see also Fig. 2). The divergent views are also well-documented by the tables of Malinowska (1991), Wright (1996a), Cariou et al. (1997) and Matyja \& Wierzbowski (1997).

The problems of Upper Oxfordian correlation, concentrated mainly on the correspondence of the $E$. bimammatum, I. planula and $S$. galar Zones to the R. pseudocordata, P. baylei, A. regulare, A. rosenkrantzi and $A$. baubini Zones, are under discussion (Wierzbowski 1991; Atrops et al. 1993b; Atrops \& Meléndez 1994b; Schweigert 1995a, b; Cariou et al. 1997; Matyja \& Wierzbowski 1997; Schweigert \& Callomon 1997). This aspect is especially relevant to the OxfordianKimmeridgian boundary problem and is therefore discussed in more detail below.

\section{Chronometric data}

The duration of the Oxfordian Stage is estimated at 5.3 Ma (Gradstein et al. 1995; Ogg 1995; Ogg \& Gutowski 1996); for precise data, see Figure 2.

\section{Kimmeridgian (Fig. 4)}

Following the Luxembourg recommendations of 1962 and 1967 (Maubeuge 1964, 1970), two possibilities existed with respect to usage of the Kimmeridgian Stage, namely either a long version ('sensu anglico') or a short version ('sensu gallico'), both with differing zonal content and boundaries (see below). Use of two different versions of the Kimmeridgian evoked much confusion in following years and led to endless discussion. Therefore a vote of the International Subcommission on Jurassic Stratigraphy (ISJS) on this question was arranged in 1990, simultaneously with the vote on the Tithonian Stage (see below); the members of the ISJS voted for a 'short' version of the Kimmeridgian Stage (i.e. 'sensu gallico'). This meant that in future the upper boundary of the Kimmeridgian Stage should be coincident with the lower boundary of the Tithonian Stage and its Boreal equivalent, the Volgian (Zeiss 1991a). The lower boundary of the stage, however, remained ambiguous (see below).

Because of the still unresolved problems at the Oxfordian-Kimmeridgian boundary, the lower boundary of the Kimmeridgian Stage is drawn in this paper at the base of the Sutneria platynota Zone, following the above-mentioned adoption of a short Kimmeridgian Stage (i.e. 'sensu gallico' or according to the 'continental' concept; Enay 1980b). The Working Group of the Oxfordian-Kimmeridgian Boundary is mandated to finally define the boundary at a level which allows farreaching correlations and corresponds to the resolutions of the International Commission on Stratigraphy (ICS); see also the discussions by Wierzbowski $(1999,2001)$. 


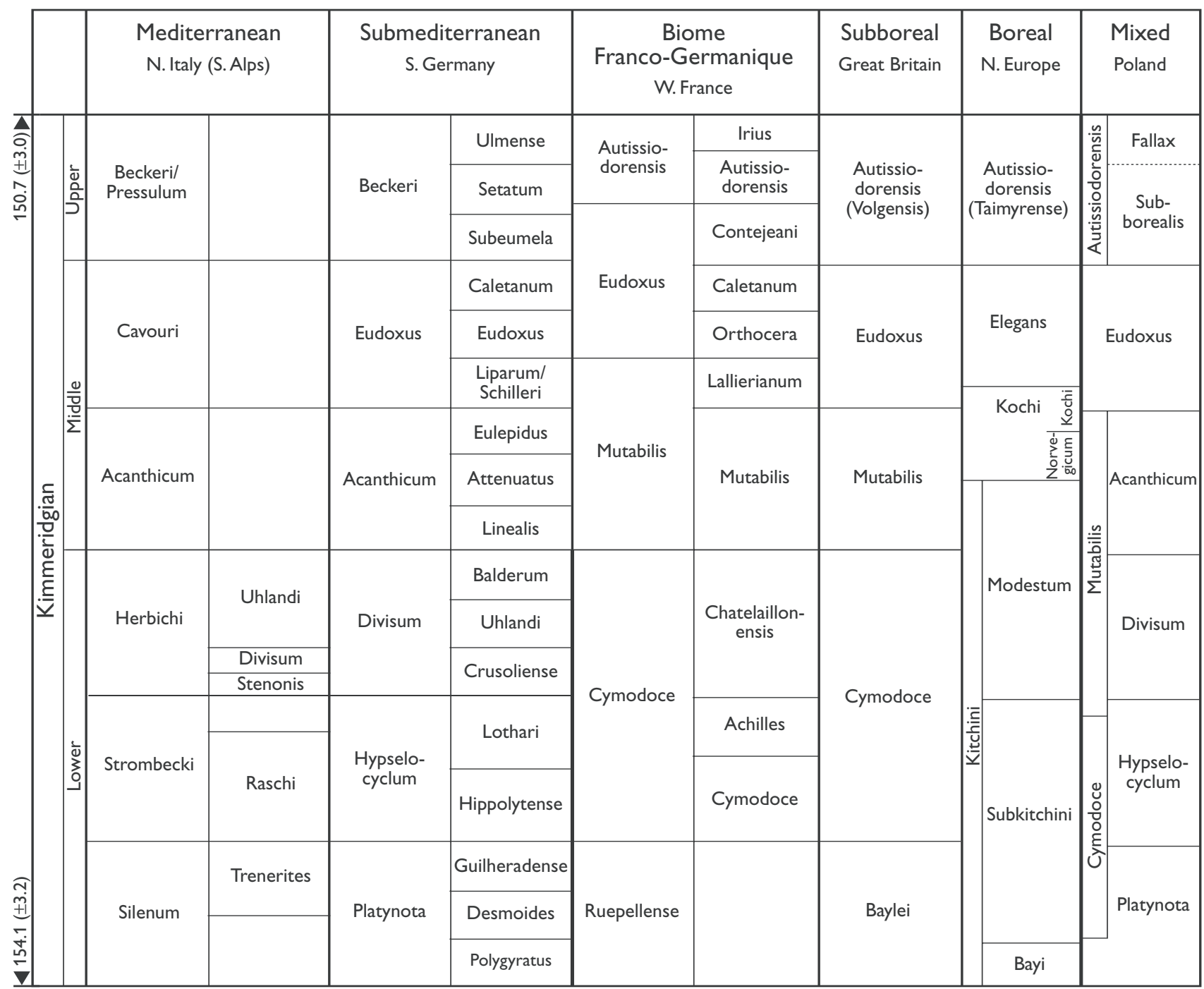

Fig. 4. A tentative correlation chart for the Kimmeridgian Stage in Europe (thick lines as in Fig. 2). Modified after Zeiss (1965), Atrops (1982), Sarti (1988), Hantzpergue et al. (1991), Wierzbowski \& Smelror (1993), Kutek \& Zeiss (1994), Schweigert \& Zeiss (1994) and Matyja \& Wierzbowski (1997, 1998).

Until such a definition has been taken by the Oxfordian-Kimmeridgian Boundary Working Group, voted on by the ISJS and approved by ISC, it seems useful to maintain the traditional boundaries in both biogeographic provinces, and it is premature to draw the Oxfordian-Kimmeridgian boundary in the Submediterranean area in the upper part of the E. bimammatum Zone (cf. Gygi 2000a, b).

\section{Lower boundary}

As the Luxembourg recommendations made it possible to select between two distinct versions of the Kimmeridgian Stage, the lower boundary was also defined twofold. In Subboreal regions of Europe, the boundary was drawn at the lower boundary of the Pictonia baylei Zone, whereas in Submediterranean regions it was placed at the base of the Sutneria platynota Zone (Maubeuge 1964, p. 85-86). At that time, it was supposed that both boundaries were more or less isochronous (Ziegler 1964), although doubts remained (e.g. Zeiss 1965; Cariou et al. 1971).

With the publication of Sykes \& Callomon (1979), new impetus was given to further studies, which have suggested that the assumed time equivalence is erroneous or, at best, only partially true (Matyja \& Wierzbowski 1988; Wierzbowski 1991; Atrops et al. 1993b; Schweigert 1995a, b). The main reasons for this view were the discovery of new Amoeboceras faunas by these authors 
and a re-evaluation of Salfelds (1915) Cardioceras paper as well as that of Koerner (1963), particularly with respect to their remarks concerning the type locality and possible type horizon of Cardioceras ( $=$ Amoeboceras) baubini. The discussion of Wierzbowski (1991) concerning the range of the genus Ringsteadia in Poland is also important in this context. It soon became evident that Amoeboceras baubini has its type horizon just below the upper boundary of the E. bimammatum Zone, (see A. Zeiss in: Enay \& Meléndez 1984). The studies of Schweigert (1995a, b; Schweigert \& Callomon 1997) resulted in similar conclusions, but led to a more precise faunal horizon subdivision of the Upper Oxfordian in Württemberg, SW Germany and to better correlation possibilities with England, with respect to the A. baubini and the A. bayi $(?=A$. subtilicaelatum $)$ horizon.

Some problems remained unsolved, however:

1. Does the A. baubini horizon of southern Germany represent the same time interval as the beds bearing A. baubini in England, Scotland and the Barents Sea? Or is there a difference, and the vertical range of this species is different in these two areas? What is the situation in Poland, representing an intermediate region?

2. Does the A. subtilicaelatum horizon of southern Germany represent the same time interval as the $A$. bayi horizon in England? Or is there also a difference in the vertical range of these species in different parts of Europe?

3. Which units in the Subboreal realm correspond to the succession from the base of the I. planula Zone (with three or four faunal horizons) and the top of the lower $S$. galar Zone, which in Submediterranean Europe occurs between the $A$. baubini and the $A$. subtilicaelatum $(?=$ A. bayi) horizon?

It is not easy to answer these questions given the present state of knowledge; the following points are pertinent prior to discussion of these problem areas. The usage of $A$. baubini as an index ammonite began with its introduction by Sykes \& Callomon (1979) as a subzone of the $A$. rosenkrantzi Zone (uppermost Oxfordian); its stratigraphic position was subsequently revised by Birkelund \& Callomon (1985), who regarded the $A$. baubini Subzone and the P. baylei Zone (Lower Kimmeridgian) as approximate equivalents. One year prior to this latter publication, A. Zeiss (in: Enay \&
Meléndez 1984, fig. 6) had used A. baubini informally as a zonal index in a correlation chart to show its approximate correspondence with the I. planula Zone sensu lato; this view was also held by Atrops et al. (1993b) and Matyja \& Wierzbowski (1997, 1998). Wierzbowski \& Smelror (1993) established the A. baubini Zone formally and suggested that it was equivalent to only the lower part of the $P$. baylei Zone (the $P$. densicostata horizon); in more recent papers, Matyja \& Wierzbowski (1994, 1995, 1997, 1998) provided charts showing the correlation between the A. baubini Zone and the I. planula Zone sensu lato as well as with the P. baylei Zone (with the exception of the uppermost part). Finally, in southern Germany, an A baubini horizon was described by Schweigert (1995b; Schweigert \& Callomon 1997) in the upper part of the T. hauffianum Subzone (uppermost E. bimammatum Zone); the latter authors correlated the Boreal A. baubini Zone with the I. planula Zone sensu stricto, whereas the $S$. galar Zone was correlated with the Amoeboceras kitchini Zone.

The Amoeboceras bayi horizon was introduced by Birkelund \& Callomon (1985) in the upper part of the P. baylei Zone, whereas Wierzbowski \& Smelror (1993) reported the species at the base of their A. subkitchini Subzone. Atrops et al. (1993b) found the species, or closely related forms, in the Sutneria platynota Zone of the Submediterranean area. Schweigert (1995b) established an A. subtilicaelatum horizon in the uppermost part of the Sutneria galar Zone, assuming that A. bayi is only a variant of $A$. subtilicaelatum, which would then have priority. This conflicts with the opinion of Salfeld (1915), that A. lineatum and A. subtilicaelatum are very close and perhaps synonymous. Schweigert (1995b) also assumed that many specimens determined earlier as ' $A$. baubini' belong in reality to $A$. bayi. To verify these assumptions, a comprehensive re-evaluation of the Upper Oxfordian - Lower Kimmeridgian Amoeboceras species complex (A. baubini-A. bayi-A. subtilicaelatum $-A$. lineatum) would be necessary. Such a study should also illustrate the variation within each species in time and space (see, for example, Klieber 1981; Birkelund \& Callomon 1985; Matyja \& Wierzbowski 1988, 1994; Schweigert \& Callomon 1997).

For the time interval of the I. planula Zone, Malinowska (1991) established the A. lineatum Subzone in Poland. It was introduced as the upper subzone of the R. pseudocordata Zone, but the precise correlation with other areas is not clear; from the list of fossils one would conclude that the $S$. galar Zone is not present. However, as a Sutneria sp. (of the galar/praecursor group?) is mentioned in the text but not figured, a deci- 
sion is difficult; its low stratigraphic level in the Goldap section would favour the $S$. praecursor Zone. In addition, Wierzbowski (1978) has described A. lineatum and $A$. baubini together from the lower part of the $I$. planula Zone; thus, the A. lineatum Subzone seems to correspond to the lower part of the P. baylei Zone rather than to the upper part of the $R$. pseudocordata Zone. Malinowska (1988) reported specimens of A. baubini only from the Lower Kimmeridgian, but these forms belong to other species such as $A$. bayi or $A$. cf. cricki.

In the Subboreal province, the Pictonia baylei Zone consists of two or three horizons. The lowermost horizon in Great Britain and the Boulonnais area is the Pictonia densicostata horizon; as mentioned above, this probably corresponds to the A. baubini horizon. In the Boulonnais and Normandy areas, this is followed by the Pictonia baylei horizon sensu stricto, and, more widespread in France, the P. baylei and P. thurmanni horizon. In Dorset, the second horizon is apparently missing (Hantzpergue 1989), while the third one is represented by the $P$. baylei and $P$. normandiana horizon, which can also be observed in East Greenland ( $P$. aff. normandiana horizon, Birkelund \& Callomon 1985). $P$. normandiana is regarded as a synonym of $P$. thurmanni by Hantzpergue (1989). This third horizon also contains $A$. bayi.

What conclusions can be made from all these observations?

1. It seems likely that $A$. baubini has a longer range in south Germany, as suggested by the many records of this ammonite species from the E. hypselum Subzone of the E. bimammatum Zone to the I. planula and $S$. galar Zones and even from the S. platynota Zone; a number of these determinations, although probably not all, may however be erroneous (Schweigert 1995b). Data from Poland also demonstrate that the range of $A$. baubini is not restricted to the upper $T$. hauffianum Zone (=A. baubini horizon), but extends as in southern Germany from the upper E. hypselum Subzone of the E. bimammatum Zone to the top of the I. planula Zone sensu lato (Matyja \& Wierzbowski 1997, 1998). It is likely, therefore, that the $A$. baubini Zone is of longer duration in the Submediterranean area, because it comprises not only the A. baubini horizon of the upper T. hauffianum Subzone, but also three or four horizons of the I. planula Zone sensu stricto and at least one horizon of the lower $S$. galar Zone. As mentioned above, Malinowska (1991, p.16-17) apparently introduced the term $A$. lineatum Subzone for such an extended $A$. baubini Zone. Approximately the same time interval has been called the A. baubini Subzone (of an unnamed zone) by Matyja \& Wierzbowski (1994, 1995) and subsequently elevated to the $A$. baubini Zone (Matyja \& Wierzbowski 1997, 1998); this zone is now correlated with the upper E. bimammatum Zone and the I. planula Zone sensu lato. It should also be noted that there is some evidence, at least in Scotland, that above the P. densicostatum bed follows another, younger bed with A. baubini and Pictonia sp. (Wright 1989). This could be a hint that there are some more beds with $A$. baubini, but without $P$. densicostata, which could correspond to the higher horizons of the $P$. baylei Zone.

In England, in contrast, Cox \& Richardson (1982) observed $A$. baubini in the uppermost part of the $A$. rosenkrantzi $(=R$. pseudocordata) Zone. If these determinations are correct, $A$. baubini may occur a little earlier than the $P$. densicostata horizon. One can conclude from these observations that the range of $A$. baubini, even in the Subboreal regions, is not restricted to the $P$. densicostata horizon or the ' $A$. baubini Zone' sensu Wierzbowski \& Smelror (1993).

2. If it can be confirmed that Amoeboceras bayi and Amoeboceras subtilicaelatum are synonymous, as assumed by Schweigert (1995b), then the upper horizon of the Sutneria galar Zone (A. subtilicaelatum horizon) may correspond to the Amoeboceras bayi horizon of the lowermost Kimmeridgian Amoeboceras kitchini Zone. It should be noted, however, that $A$. bayi has also been reported from the lower ('Orthosphinctes') horizon of the S. platynota Zone (Atrops et al. 1993b).

3. (a) It can be concluded from the above that correlation of the A. baubini and $P$. densicostata horizon with the $A$. subtilicaelatum and $A$. bayi horizon is possible, but the vertical ranges of the former species may be longer and the correlation may thus be only partial. Consequently, the position of the upper boundary of the A. baubini Zone and the lower boundary of the $A$. bayi horizon require more precise definition.

(b) In the sequence between the A. baubini and the A. subtilicaelatum horizons, equivalent to the middle part of the Pictonia baylei Zone, the P. baylei horizon of Normandy and the upper A. baubini-bearing beds in Scotland (e.g. bed 38 with Pictonia sp., Wright 1989) could be expected. They may have 
their equivalents anywhere in this succession, whereas other parts of the Submediterranean succession are not represented in the Subboreal sections or only by gaps.

(c) The inclusion of this part of the Submediterranean subdivision in an A. lineatum Subzone (Malinowska 1991) with its unprecise limits (in southern Germany, the species is known to occur in the Upper Oxfordian and Lower Kimmeridgian) will not help significantly; this subzone can be replaced by the $A$. baubini Zone, as used by Matyja \& Wierzbowski (1997, 1998).

(d) There are apparently different possibilities of correlation and further research is necessary to clarify the situation.

(e) The Subboreal Oxfordian-Kimmeridgian boundary ( $R$. pseudocordata/P. baylei Zone) can, with a high degree of probability, be positioned within the Submediterranean and Mediterranean scheme in the uppermost part of the E. bimammatum Zone on the basis of the correlation of the A. baubini horizon with the $P$. densicostata horizon. The Submediterranean Oxfordian-Kimmeridgian boundary remains at the base of the S. platynota Zone.

\section{Additional remarks on Lower Kimmeridgian correlation}

As mentioned above, the upper $S$. galar Zone ( $A$. subtilicaelatum horizon) is probably an equivalent of the Amoeboceras bayi horizon (Schweigert 1995a), which extends into the lower part of the S. platynota Zone (Amoeboceras horizon with $A$. bayi, see Atrops et al. 1993b). This contrasts somewhat with the correlation of Birkelund et al. (1983, table 1), who considered the Pictonia baylei Zone and the Paraspidoceras rupellense Zone of Hantzpergue (1979) to be equivalent. Hantzpergue (1989), too, correlated the $P$. baylei Zone with the $P$. rupellense Zone (horizons R1 and R2); horizons P1-3 of the I. planula Zone sensu lato are considered to be equivalent to the $R$. pseudocordata Zone sensu lato (Hantzpergue 1989, tables E, F). In his sections, he found the Upper Oxfordian Sutneria galar in the Lithacosphinctes gigantoplex horizon (P3), immediately below his P. rupellense Zone (see Fig. 2).

The $P$. rupellense Zone itself is situated between the gigantoplex horizon (P3) of the uppermost Idoceras planula Zone sensu lato and the Rasenia cymodoce
Zone (Fig. 4); it is therefore considered to be equivalent to the lowermost Submediterranean Kimmeridgian (S. platynota Zone; Schairer 1970; Atrops 1982; Olóriz \& Rodríguez-Tovar 1996); its lower horizon (R1) seems to correspond to the upper part of the lower ('Orthosphinctes') subzone of the S. platynota Zone, whereas the lower part (Amoeboceras horizon) of this zone is not represented; its upper horizon (R2) contains the index 'Ardescia virgatoides', which is similar to forms of the Ardescia desmoides horizon of the Ardescia desmoides Subzone of the middle Sutneria platynota Zone and is therefore very important for correlation to the Submediterranean region.

Above the P. ruppelense Zone, Hantzpergue (1989) subdivided the Rasenia cymodoce Zone into nine horizons (C1-9); the R. cymodoce horizon (C2) could be traced from western France to Normandy and the Subboreal regions. In northern Europe, the $R$. cymodoce horizon is rather widespread (Wierzbowski 1989) and in Spitsbergen it represents the only rasenoid horizon within the Amoeboceras succession. In East Greenland, Birkelund \& Callomon (1985, fig. 5) recognised two other horizons below the horizon of Rasenia cymodoce ('17'), namely the 'Pachypictonia' horizon ('16') and the Rasenia inconstans horizon ('15'). These horizons of the lower $R$. cymodoce Zone were considered to be equivalent to the $P$. altenense horizon (C1; Hantzperque 1989); they are probably equivalent to the lower Ataxioceras hippolytense Subzone of the lower Ataxioceras bypselocyclum Zone of south-east France, whereas the $R$. cymodoce horizon perhaps has its equivalents in the upper part of this subzone.

In the middle and upper part of the R. cymodoce Zone, only a few possibilities remain for far-reaching correlations in Europe, such as the Eurasenia aulnisa horizon (C5), which contains the highly characteristic Submediterranean subzonal index $A$. lothari, and the Semirasenia askepta horizon (C7), which has been found in Scotland, England, Normandy, western France (Birkelund \& Callomon 1985; Hantzpergue 1989) and southern Germany (Heller 1964; Doben \& Heller 1968). In northern Germany, Submediterranean ammonites of Early Kimmeridgian age have been found in sediments which had earlier been attributed to the Upper Oxfordian (Fischer 1991).

\section{Substages}

The Kimmeridgian Stage has been subdivided into two or three substages; here a subdivision into three sub- 
stages is preferred. If the Middle Kimmeridgian is not recognised, then the middle and the upper part are united as Upper Kimmeridgian (Fig. 4).

\section{Zones}

In the Mediterranean and Submediterranean provinces, the Lower Kimmeridgian consists of three zones, which can be correlated approximately as follows: (1) Sowerbyceras silenum - Sutneria platynota, (2) Ataxioceras bypselocyclum - Taramelliceras strombecki and (3) Crussoliceras divisum - Mesosimoceras herbichi (Fig. 4). Their further subdivision into subzones is different in both areas (Fig. 4); precise correlation of these units is thus difficult (Pavia et al. 1987; Sarti 1993). Detailed subdivisions into subzones and faunal horizons have been proposed in south-east and western France (Atrops 1982; Hantzpergue 1989); that of south-east France can also be used with some minor changes in southern Germany. The Submediterranean zonal subdivision as established by Geyer (1961) can be used from the Iberian Peninsula to Bulgaria and Turkey (Sapunov 1977a; Lopez Marques 1983; Alkaya 1992). In Poland, the Submediterranean zonal subdivision has been adopted by Malinowska (1988) and Matyja \& Wierzbowski (1998). In Subboreal and Boreal regions, subdivision into two zones is typical (see above): (1) Pictonia baylei and (2) Rasenia cymodoce. These zones can be replaced by the Amoeboceras kitchini Zone in areas where no perisphinctids occur (e.g. Wierzbowski \& Smelror 1993); this zone may extend into the lower part of the Aulacostephanus mutabilis Zone (see below).

The Middle and Upper Kimmeridgian Substages together consist of three zones in all parts of Europe (Fig. 4).

1. In Mediterranean and Submediterranean Europe: (1) Aspidoceras acanthicum Zone, (2) Mesosimoceras cavouri or Aulacostephanus eudoxus Zone and (3) Hybonoticeras pressulum/H. beckeri or $H$. beckeri Zone.

2. In Boreal and Subboreal Europe: (1) Aulacostephanus mutabilis Zone, (2) A. eudoxus Zone and (3) A. autissiodorensis Zone.

In regions where no perisphinctids are present, these latter zones can be replaced in the lowermost parts by the Amoeboceras kitchini Zone (see above) followed by the A. kochi, A. elegans and Suboxydiscites taimyren- sis Zones (Fig. 4). The latter index has been taken from northern Siberia charts (Birkelund \& Callomon 1985), but there is no mention of this species in more western regions, with the exception of a determination from the Middle Kimmeridgian of Greenland. Therefore, for these Boreal regions too, Aulacostephanus autissiodorensis seems to represent the more appropriate index species.

The Middle Kimmeridgian zonal and subzonal subdivisions can be applied without great difficulty in Boreal, Subboreal and Submediterranean Europe, as there are large regions with overlapping guide fossils, whereas in the Mediterranean province, only a zonal subdivision is possible. Hantzpergue (1989) established a detailed subdivision in western France, which can also be used in northern France (Geyssant et al. 1993; Proust et al. 1993) and traced as far as Germany (Zeiss 1991b; Schweigert 1993a, 1996a), England, Norway and East Greenland (Hantzpergue 1989).

An unresolved problem is the lower boundary of the A. mutabilis Zone; it is drawn at the base of the A. lineatum horizon in western and northern France (Hantzpergue 1989; Hantzpergue et al. 1997), but in England, following the revisions of Birkelund et al. (1983), it is placed four horizons deeper, at the base of the $S$. askepta horizon. Recent investigations in central Poland came to similar results (Matyja \& Wierzbowski 1998); these workers traced the boundary to a slightly deeper level in the upper A. hypselocylum Zone. In Germany and the Submediterranean region, the usage from south-east France has been followed (Hantzpergue 1989; Hantzpergue et al. 1991; Zeiss 1991b), which facilitates correlation with the base of the A. acanthicum Zone; the lower boundary of this zone in Germany is traditionally drawn at the incoming of the first representatives of the genus Aulacostephanus (lineatum group). In a recent publication by Hantzpergue et al. (1997), the problems of this boundary are well illustrated by their table 12; in the 'Biome Franco-germanique', the lower boundary of the A. mutabilis Zone is drawn below its lowermost horizon (linealis horizon), whereas the base of the A. mutabilis Subzone, curiously, is placed two horizons higher (attenuatus horizon). It is evident that the new data from Poland (Matyja \& Wierzbowski 1998), which place the base of the $A$. mutabilis Zone much deeper, will probably necessitate revision of all these correlations.

Amoeboceras subdivisions are important from Norway to Spitsbergen (Wierzbowski 1989; Wierzbowski \& Århus 1990; Wierzbowski \& Smelror 1993) and East Greenland (Birkelund \& Callomon 1985). 
In the Upper Kimmeridgian (upper A. autissiodorensis Zone) of Poland and the Russian platform, a Sarmatisphinctes fallax Subzone has been established (Mesezhnikov 1984, 1988; Kutek \& Zeiss 1994, 1997). For the lower part (lower A. autissiodorensis Zone), the Discosphinctiodes subborealis Subzone is proposed; D. subborealis is a significant index fossil. In Poland, Aulacostephanus autissiodorensis has been found only in the lower and middle parts of the $S$. fallax Subzone. In western Siberia, a zone of Virgataxioceras dividuum is the equivalent of the $S$. fallax Subzone (Mesezhnikov 1988). In northern Germany, Schweigert (1996a) stated, based on re-study of previous collections, that the $A$. autissiodorensis Zone is probably present.

In southern Germany, where subdivision into two subzones was previously adopted, new discoveries of ammonites have made it possible to organise the $H$. beckeri Zone into three subzones: (1) Sutneria subeumela, (2) Virgataxioceras setatum and (3) Lithacoceras ulmense (Schweigert \& Zeiss 1994, 1999); further subdivision into several faunal horizons is possible (Schweigert 1996b, 1998). Furthermore, Schweigert (1993a, b, 1994) discovered ammonites in the Upper Kimmeridgian of Swabia with a Subboreal habitus, providing better correlation possibilities between the Subboreal $A$. autissiodorensis and Submediterranean H. beckeri Zones (see below).

For the Upper Kimmeridgian of western France, a useful subdivision has been proposed by Hantzpergue (1989), who subdivided the A. autissiodorensis Zone into two subzones, the $A$. autissiodorensis and the Gravesia irius Subzones, each with two faunal horizons. The succession in the Boulonnais area and farther north has been worked out in detail by Geyssant et al. (1993) and Geyssant (1994); the succession in southern England was reported by Cox \& Gallois (1981), Birkelund et al. (1983) and Callomon \& Cope (1996).

\section{Correlation}

Many difficulties are encountered in correlating zones (and subzones) of the Lower Kimmeridgian in Europe, mainly between the Submediterranean and Subboreal regions, but also between the Submediterranean and Mediterranean areas (Fig. 4). Many correlations are arbitrary and well-constrained correlation is only possible at certain levels. Such correlation possibilities in the Lower Kimmeridgian Substage have already been explained in connection with the problems of the Oxfordian-Kimmeridgian boundary.
Some problems exist around the Lower-Middle Kimmeridgian boundary, as the base of the A. mutabilis Zone is variably defined in different parts of Europe (see above). Considering the most recent results from Poland (Matyja \& Wierzbowski 1998), the lower boundary of the Subboreal $A$. mutabilis Zone lies within the uppermost part of the Submediterranean A. bypselocyclum Zone, i.e. one zone deeper than previously assumed.

In the Middle Kimmeridgian Substage, correlations within the A. acantbicum/A. mutabilis Zones and the $A$. eudoxus Zone pose no great problems although the uppermost part of the $A$. eudoxus Zone of western France (A. contejeani Subzone) seems to correspond to the lower part of the $H$. beckeri Zone in south Germany (Schweigert 1993b). Correlation of the A. kochi Zone with the upper part of the $A$. mutabilis and/or the lower part of the A. eudoxus Zone (Wierzbowski \& Smelror 1993) is still tentative, as is the correlation of the A. elegans Zone with most of the A. eudoxus Zone.

Correlation of the Upper Kimmeridgian Substage (Submediterranean $H$. beckeri Zone with the Subboreal A. autissiodorensis Zone) was hitherto only possible by indirect arguments. The elaboration of a new zonal and subzonal subdivision in western France by Hantzpergue (1989) and the new discoveries by Schweigert (1993a, b, 1994) in Germany and by Kutek \& Zeiss (1997) in Poland now permit correlation of parts of the Upper Kimmeridgian of western, central and eastern Europe and perhaps also western Siberia.

\section{Chronometric data}

The duration of the Kimmeridgian Stage has been estimated to be 3.4 Ma (Gradstein et al. 1995; Ogg 1995; Ogg \& Gutowski 1996); for precise data, see Figure 4.

\section{Tithonian and Volgian (Fig. 5)}

The Tithonian, and its Boreal equivalent the Volgian, have been confirmed as stage names by a vote of the International Subcommission on Jurassic stratigraphy in 1990 (Zeiss 1991a). A further stage name 'Bononien' (for the 'Upper Kimmeridgian sensu anglico', proposed by Cope 1993) seems unnecessary and could result in each region with a differing zonal subdivision claiming its own stage name, leading only to more confusion rather than to international agreement concerning uniform nomenclature. Furthermore, due to the different meanings of the stage 'Portlandian' in different 


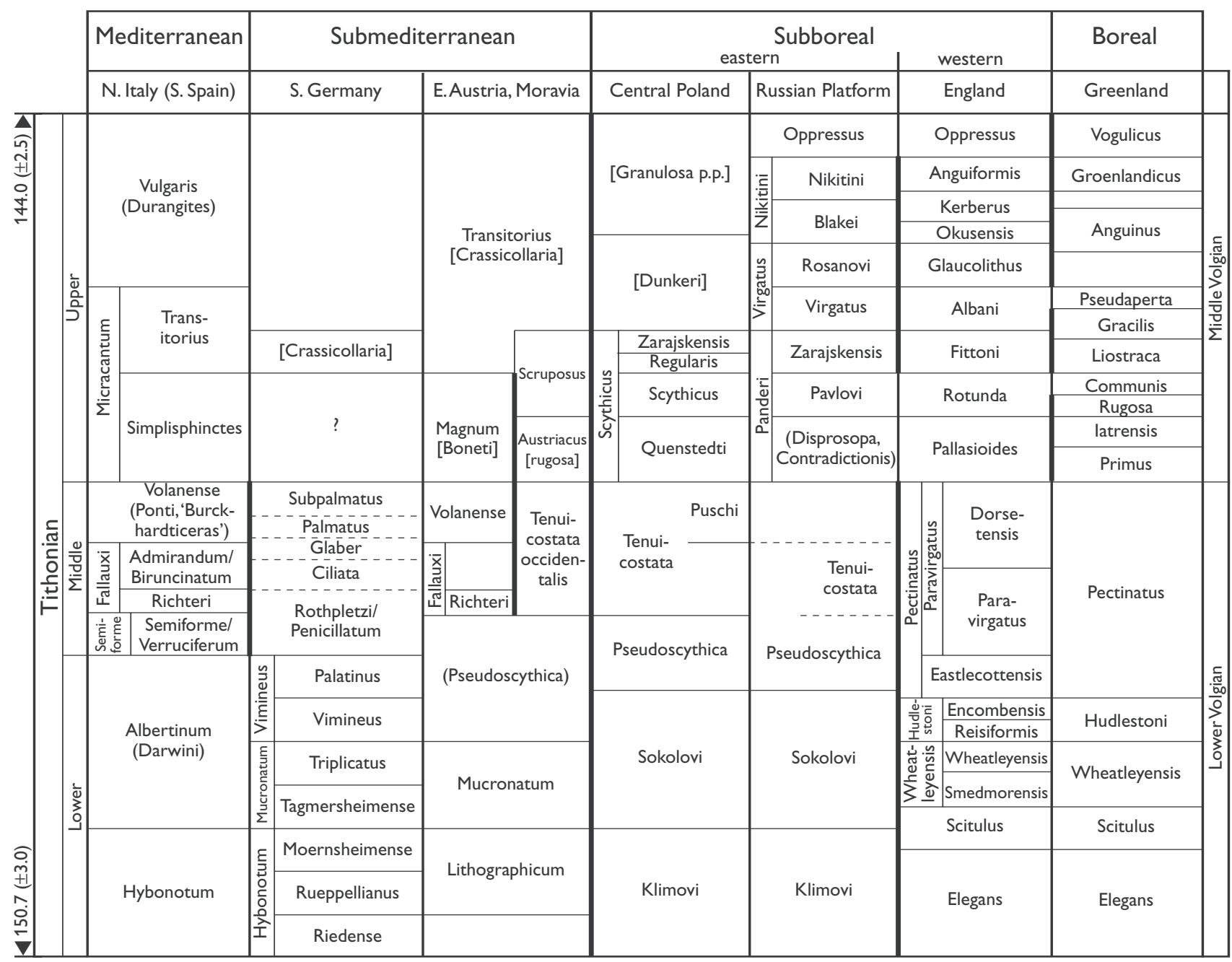

Fig. 5. A tentative correlation chart for the Tithonian and Volgian Stages in Europe (thick lines as in Fig. 2). Modified after Barthel (1964), Zeiss (1968, 2001), Cope et al. (1980), Callomon \& Birkelund (1982), Kutek \& Zeiss (1988, 1997), Mesezhnikov (1988), Sarti (1988), Zeiss \& Bachmayer (1989), Mitta (1993), Kutek (1994) and Geyssant (1997). Non-ammonite taxa are indicated in square brackets.

countries, it was voted in 1990 that usage of this name should be discontinued. The most recent review of the Tithonian Stage and its ammonites is that provided by Geyssant (1997); for the Volgian Stage and ammonite biostratigraphy, see Gerasimov et al. (1995), Callomon \& Cope (1996) and Kutek \& Zeiss (1997).

\section{Lower boundary}

The base of the Tithonian Stage is defined by the base of the Hybonoticeras bybonotum Zone. It is generally supposed that the base of the coeval Gravesia gigas, Virgatosphinctoides elegans and Ilowaiskya klimovi Zones are drawn at approximately the same time level (see also below).

\section{Substages}

The Tithonian is subdivided into two or three substages; here preference is given to a tripartite Tithonian Stage (Fig. 5). If only two substages are used, then the lower and middle part are united as the lower substage ('Danubian'), the upper substage corresponds to the 'Ardescian' substage. Type regions for the Lower and Middle Tithonian Substages have been proposed by Barthel (1975) and Zeiss (1975). The type region for the Upper Tithonian Substage, the Ardescian, has been revised by Cecca et al. (1989a, b).

The subdivision of the Volgian is threefold, into lower, middle and upper substages. The lower and middle substages ('Gorodishchian') correspond roughly to the Tithonian Stage (Fig. 5), whereas the upper substage 
('Kashpurian') belongs to the Cretaceous System (Sasonova \& Sasonov 1979; Zeiss 1983, 1986; Sey \& Kalacheva 1993a; W.A. Wimbledon in: Callomon \& Cope 1996). A type section for the Volgian Stage has been proposed by Gerasimov \& Mikhailov (1966).

\section{Zones and Subzones}

Whereas the two lower stages of the Upper Jurassic have two main zonal subdivisions, at least four subdivisions are necessary in the upper stage (Fig. 5). This is due to the extreme provincialism of ammonites caused by the increasing isolation of late Jurassic marine basins, which seem to have only rarely been directly connected; interbasinal migration was apparently only favoured during the lowermost zone of the stage.

The most important lower zone is that of Hybonoticeras bybonotum, which can be followed over long distances in Mediterranean and Submediterranean Europe (Zeiss 1968; Olóriz 1978; Sapunov 1979; Sarti 1988); in southern Germany it is possible to recognise three subzones and seven horizons in the H. bybonotum Zone (Schweigert \& Zeiss 1999). In central Europe, the latter overlaps with the Gravesia gigas Zone, which has a rather wide distribution regionally in central and western Europe. During the last decades, many new discoveries have been reported and the genus Gravesia and the stratigraphy of the beds with Gravesia have been revised (Hahn 1963; Zeiss 1974; Hantzpergue 1989; Schweigert 1994, 1996a, b; Schweigert et al. 1996; Zeiss et al. 1996; Dimke \& Zeiss 1997). In the Subboreal subprovince, the genus Gravesia is also present, but less numerous, so that other index fossils have been given priority, such as Virgatosphinctoides elegans in northwestern and Ilowaiskya klimovi in eastern Europe (Cope 1967; Cope et al. 1980; Kutek \& Zeiss 1974, 1994, 1997; Callomon \& Birkelund 1982; Mesezhnikov 1988). According to Callomon \& Cope (1996), Gravesia cf. gravesiana occurs in the lower part of the Virgatosphinctoides scitulus Zone, thus demonstrating the correlation with the upper $H$. bybonotum Zone (containing G. gravesiana). In northern Germany, beds with Gravesia gigas intermedia are apparently the youngest beds containing Jurassic ammonites (Schweigert 1996a) and are succeeded by brackish and freshwater sediments up to the Jurassic-Cretaceous boundary. In these beds, ostracodes have proved to be the best guide fossil (Bischoff \& Wolburg 1963; Schudack 1994, fig. 24), permitting subdivision of the Tithonian Stage in northwest Germany into four zones. In other areas, such as eastern England and Denmark, subdivision into nine zones is possible using ostracodes (Christensen 1988; Schudack 1994, fig. 24).

The upper zone of the Lower Tithonian in Mediterranean Europe, the zone of Semiformiceras darwini (or of Virgatosimoceras albertinum), is apparently equivalent to the Neochetoceras mucronatum and Franconites vimineus Zones (each of them with two subzones and some horizons) of Submediterranean Europe, as they have numerous faunal elements in common (Enay \& Geyssant 1975; Olóriz 1978; Cecca et al. 1986; Sarti 1984, 1988; Cecca 1990a, b). Precise correlations have still to be worked out, however, and at present this is difficult as no subzones or even horizons have been recognised in the Tethyan realm. The Submediterranean zones have been traced from south-east France via southern Germany to Hungary as well as in Bulgaria and perhaps also Turkey (Zeiss 1968; Sapunov 1977b, 1979; Vigh 1984; Fözy 1988, 1993; Alkaya 1989; Atrops 1994; Fözy et al. 1994). Correlation with the Subboreal regions is only tentative and different proposals have been published (Fig. 5; Zeiss 1977; Mesezhnikov 1988; Kutek \& Zeiss 1997).

In Subboreal Europe, the situation is not much better and correlations between the different subprovinces of Northwest and eastern Europe are only approximate. Consequently, different zonal subdivisions are also applied in these subprovinces. In eastern Europe, for example, species of the genus Ilowaiskya are used (e.g. the Ilowaiskya sokolovi and I. pseudoscythica Zones; Mesezhnikov 1988; Kutek \& Zeiss 1997), whereas in Northwest Europe, representatives of the genera Virgatosphinctoides, Arkellites and Pectinatites have been selected (e.g. the Virgatosphinctoides scitulus, W. wheatleyensis, Arkellites budlestoni and Pectinatites pectinatus Zones); each of these latter zones can be subdivided into two subzones (Cope et al. 1980; Callomon \& Birkelund 1982; Geyssant 1997).

For the Middle Tithonian Substage, the subdivisions in Mediterranean and Submediterranean Europe are rather distinct (Fig. 5). Furthermore, minor faunal differentiations exist within the Mediterranean area, and different zonal indexes are used for the same time interval (Enay \& Geyssant 1975; Olóriz 1978; Cecca \& Santantonio 1988; Sarti 1988): (1) Semiformiceras semiforme or Haploceras verruciferum, (2) Semiformiceras fallauxi or (2a) Richteria richteri and (2b) Simoceras admirandum/biruncinatum (or S. biruncinatum), and (3) Simoceras volanense or 'Burckhardticeras' peroni or Micracanthoceras ponti. Note that Burckhardticeras Olóriz 1978 is a junior homonym of Burckhardticeras 
Flores Lopez 1967 (Schweigert \& Zeiss 1998). In the Submediterranean area of southern Germany, the following guiding ammonites have been observed (Barthel 1975; Zeiss 1986): (1) Virgatosimoceras rotbpletzi and Sublithacoceras penicillatum, (2) Lemencia ciliata, (3a) Sublithacoceras(?) glaber, (3b) Isterites palmatus, and (3c) Isterites subpalmatus. According to Scherzinger \& Schweigert (1999), a horizon with Sublithacoceras callodiscus has been observed above the level with Lemencia ciliata.

In eastern Europe, the equivalents of the Middle Tithonian Substage are probably the upper part of the Lower Volgian (upper Ilowaiskya pseudoscythica and Ilowaiskya tenuicostata Zones). The latter unit is discernable in Poland but has not been recognised in Russia to date (Kutek \& Zeiss 1974, 1988, 1994, 1997; Mesezhnikov 1988; Kutek 1994). In its upper part, the Pseudovirgatites puschi horizon is important due to its mixed fauna (Kutek \& Zeiss 1974, 1988, 1997). A local time equivalent in north-eastern Austria is probably the Isterites austriacus Zone with Buchia rugosa as an important guide fossil (Fig. 5). A quite different zonal subdivision exists in Great Britain and the adjoining Subboreal and Boreal regions as far as Greenland (Cope 1978, 1980; Wimbledon 1980; Callomon \& Birkelund 1982; Kejsi et al. 1988); the Middle Tithonian perhaps corresponds to the main part of the Pectinatites pectinatus Zone and perhaps to the Pavlovia pallasioides Zone of England or to the Dorsoplanites primus and Pavlovia iatrensis Zone of East Greenland.

The Upper Tithonian Substage consists of two or three zones in the Mediterranean area. In southern Spain, the lowermost zone has been identified as the Simplisphinctes Zone (Tavera 1985). This unit has not been identified in northern Italy (Sarti 1988), but could be recognised as far as north-eastern Austria, where the same ammonite fauna (containing the genus Oloriziceras) occurs (Zeiss \& Bachmayer 1989). In the absence of the rather peculiar index genus Simplisphinctes, this zone was called the Oloriziceras magnum Zone for this region (Zeiss 2001). Above the Simplisphinctes (or S. abnormis or O. magnum) Zone, the Paraulacosphinctes transitorius Zone (with the first Crassicollaria) occurs. A Micracanthoceras micracanthum Zone is sometimes adopted instead of the P. transitorius Zone; this zone apparently also contains the equivalents of the Simplisphinctes (better S. abnormis) Zone (Enay \& Geyssant 1975; Sarti 1988; Geyssant 1997). Some authors consider the Simplisphinctes and P. transitorius Zones as subzones of the $M$. micracanthum Zone (Benzaggagh \& Atrops 1997; Geyssant 1997) although the former authors, based on Moroccan data, only partially substituted the Simplisphinctes Subzone, replacing its upper part and the $P$. transitorius Subzone by two new subzones, that of 'Micracanthoceras (Corongoceras) spp.' and that of 'Moravisphinctes spp.'. It is very important that these new subzones can be correlated rather precisely with the calpionellid subdivision; the Chitinoidella boneti Subzone (of the Chitinoidella spp. Zone) corresponds to the first two subzones. The base of the Crassicollaria spp. Zone (Zone A) approximately coincides with the base of the Moravisphinctes spp. Subzone, which corresponds to the lower part of this zone (= Subzone A1).

The Durangites Zone follows above the P. transitorius Zone. In northern Italy, this zone was named the Durangites vulgaris Zone by Sarti (1988); this term has also been adopted by other authors. In some countries, this zone has not been recognised; the equivalents of this zone are then apparently included in the P. transitorius Zone, which sometimes even includes parts of the Lower Cretaceous (e.g. Sapunov 1977b). The fauna of this zone has been mainly described by Tavera (1985), Tavera et al. (1994) and Enay et al. (1998a, b).

During the Middle Volgian, central Poland belonged to the eastern Subboreal subprovince, but only the lowermost unit, the Zaraiskites scytbicus Zone (with the lower Z. scythicus and upper Z. zarajskensis Subzones) is represented (Kutek 1994). Brackish sediments prevail higher in the Polish section and yield ostracodes; the Cypridea dunkeri and the Cypridea granulosa Zones can be recognised. On the Russian Platform, the lowermost horizon of the $Z$. scythicus Subzone ( $Z$. quenstedti horizon in Poland) is probably represented by beds containing Zaraiskites disprosopa and Isterites(?) contradictionis (Ilovaiskij \& Florenskij 1941).

On the Russian Platform, a Dorsoplanites panderi Zone is now used instead of the Z. scytbicus Zone (Mesezhnikov 1988; Kutek 1994); above follows the Virgatites virgatus Zone (with three subzones: V. gerasimovi, V. virgatus and C. ivanovi; Gerasimov et al. 1995). The $V$. virgatus Zone is succeeded by the Epivirgatites nikitini and Lomonossovella blakei Zone (separated by Callomon \& Birkelund (1982), and, in reverse order, by Mesezhnikov (1988) but adopted as a single zone by other Russian authors (e.g. Gerasimov et al. 1995)). The uppermost Middle Volgian is represented by the Paracraspedites oppressus Zone (Mesezhnikov 1988). In the Baltic area, Middle Volgian ammonites are rare although a few specimens from Lithuania were mentioned by Rotkytè (1976, 1987). In Scandinavia, Middle Volgian ammonites have been found in Denmark 
(Birkelund \& Pedersen 1980) and in Norway (Birkelund et al. 1978). In England and East Greenland, Dorsoplanitidae are prevalent, but in both these regions, the subdivisions are distinct; in England, Pavlovia pallasioides, Pavlovia rotunda and Virgatopavlovia fittoni characterise the lower part of the Middle Volgian whereas Progalbanites albani and the giants Glaucolithites glaucolithus, Galbanites okusensis, Kerberites kerberus and Titanites anguiformis characterise the upper part (Cope 1978; Wimbledon \& Cope 1978). As in Russia, the uppermost zone is the Paracraspedites oppressus Zone (Casey 1973; Kejsi \& Mesezhnikov 1986; Kejsi et al. 1988), but not all authors adopt this zone. In East Greenland, there are some similarities with Siberian ammonite successions, but in general the subdivision there has its own character and, with three exceptions, its distinct index species (Callomon \& Birkelund 1982; Mesezhnikov 1988): Dorsoplanites primus, Pavlovia iatrensis, Pavlovia rugosa, Pavlovia communis and Dorsoplanites liostracus characterise the lower part of the Middle Volgian, whereas Dorsoplanites gracilis, Epipallasiceras pseudapertum, Crendonites anguinus, Laugeites groenlandicus and Epilangeites vogulicus are represented in the upper part. The lower part of the Upper Volgian Praechetaites tenuicostatus Zone of East Greenland may correspond to the uppermost part of the Middle Volgian, the upper Paracraspedites oppressus Zone of England and the lower Praechetaites exoticus Zone (= lowermost Craspedites okensis Zone sensu lato) of northern Siberia.

\section{Correlation}

As explained above, the basal zones of the Tithonian (and Volgian) can be correlated over long distances, but correlation becomes very difficult in the higher parts of these stages. Not only is it difficult to correlate between the Boreal and Mediterranean regions, but also within these regions. Distinct lineages of ammonites were evolving throughout the area and consequently it is necessary to develop and apply different ammonite zonal subdivisions; correlation possibilities are thus only few and mostly tentative. Many attempts have been made to correlate the different zonal subdivisions of Europe (Cope \& Zeiss 1964; Zeiss 1965, 1974a, 1979, 1983, 1986; Enay 1972; Enay \& Geyssant 1975; Olóriz 1978; Callomon \& Birkelund 1982; Jeletzky 1984, 1989; Tavera 1985; Cecca et al. 1986; Hoedemaker 1987, 1991; Kejsi et al. 1988; Kutek \& Zeiss 1988, 1997; Geyssant \& Enay 1991; Sey \& Kalacheva 1993a; Kutek 1994; W.A. Wimbledon in: Callomon \& Cope 1996; Geyssant 1997).
Due to problems of provinciality, such correlation schemes are necessarily speculative and ultimately unsatisfactory. A tentative summary correlation scheme is given in Figure 5, based on developments since earlier attempts by the author (Zeiss 1983, 1986). A similar, although in detail somewhat different, correlation chart has recently been published by Hantzpergue et al. (1998).

Concerning the Middle and Upper Tithonian (upper Lower and Middle Volgian) Substages, a number of observations are pertinent. Although correlation between the Mediterranean and Submediterranean area is quite possible in the lowermost Middle Tithonian Substage (S. semiforme/R. richteri $-V$. rothpletzi/S. pennicilatum Zones), a number of different proposals have been made for the higher zones (Enay \& Geyssant 1975; Olóriz 1978; Jeletzky 1984, 1989; Cecca et al. 1986; Kutek 1994). A satisfactory answer to this problem requires complete revision of the famous Submediterranean Neuburg fauna and sections, in which some levels with distinct ammonite faunas have already been recognised by Barthel (1964, 1975).

In eastern central Europe (north-eastern Austria, Moravia, central and southern Poland), some Submediterranean and Mediterranean ammonites genera of Middle and Late Tithonian age are represented by characteristic forms. They sometimes interfinger with Subboreal elements, thus providing good potential for correlation (Kutek \& Wierzbowski 1986; Kutek \& Zeiss 1988, 1997; Kutek 1994). The I. tenuicostata and $Z$. scythicus Zones of central and southern Poland, for example, display interesting forms with affinities to both the Submediterranean and Subboreal provinces. Combined with observations from other localities, this facilitates better correlation between these two regions: (1) the Psewvirgatites puschi horizon of the uppermost Ilowaiskya tenuicostata Zone contains Isterites species described from the higher parts of the Neuburg beds, i.e. of late Middle Tithonian age, and (2) the Z. regularis horizon of the lower $Z$. zarajskensis Subzone (upper Z. scythicus Zone) contains Pseudovirgatites scruposus and calpionellids indicative of the calpionellid Zone A, such that correlation is possible with the lower part of the Paraulacosphinctes transitorius Zone.

In the Boreal and Subboreal provinces, quite different zonal subdivisions exist, mainly based on different perisphinctid groups, such as the Pectinatitinae and Dorsoplanitinae in England, Denmark, Norway and Greenland and the Ilowaiskyinae, Virgatitinae and Dorsoplanitinae in Poland and Russia. The correlation of these zones is rather arbitrary, as demonstrated by Callomon \& Birkelund (1982), Mesezhnikov (1988) and 
W.A. Wimbledon (in: Callomon \& Cope 1996), and is based mainly on similar, but non-identical species of Dorsoplanitinae.

\section{Chronometric data}

The approximate duration of the Tithonian has been estimated to be $6.7 \mathrm{Ma}$ (Gradstein et al. 1995; Ogg 1995); for precise data, see Figure 5.

\section{Biochronological importance of non- ammonite fossil groups: a review}

The Jurassic System is the classic one for subdivision by ammonites. This fossil group has been used with much success since the pioneering work in the last century by workers such as L. von Buch, A. d'Orbigny, A. Oppel, F.A. Quenstedt, K.A. von Zittel and S. Buckman. Indeed, this contribution on the chronological subdivision of the Upper Jurassic of Europe has been compiled primarily using ammonites (see above). However, Upper Jurassic marine sediments of epicontinental shelves, the habitat of ammonites, are not present everywhere in Europe, so that ammonites are not always available. It is often necessary, therefore, to utilise other fossil groups with proven stratigraphic value such as bivalves, brachiopods, foraminifera, ostracodes and distinct plant mega-, micro- and nannofossil groups. Radiolarians, calpionellids, conchostracans, insects and vertebrates should also be added to this list; the first two groups are very useful in pelagic sedimentary basins whereas the last ones are used with much success in the stratigraphic subdivision of continental sediments, such as those of central and eastern Asia and of North America.

The challenging task of correlating between the different fossil subdivision schemes has been addressed for individual groups (e.g. Le Hégarat \& Remane 1968; Surlyk \& Zakharov 1982). Multidisciplinary correlation charts, typically for microfossil groups, have only been successfully developed within the last two decades. Useful though incomplete examples of such schemes, including micro- and macrofossils, have recently been published by Tavera et al. (1994), R. Enay (in: Cariou \& Hantzpergue 1997), Gramann et al. (1997) and Remane (1997). It remains as one of the more important tasks, however, to establish European multidisciplinary correlation charts that incorporate all fossil groups important for biochronology and also include radiometric ages and palaeomagnetic reversal data. During the editorial work, it was brought to the attention of the author that charts fulfilling many of these expectations have recently been published by Hardenbol et al. (1998, charts 6-7); of special interest are the chronometric data for most of the biochronostratigraphic units (see below).

\section{Invertebrate megafossil groups}

\section{Cephalopods - other than ammonite conchs}

\section{Aptychi}

In the Tethyan regions, aptychi have proven to be a useful addition to ammonites for the subdivision of Upper Jurassic sediments. Following the studies of Durand \& Gąsiorowski (1970) and Gąsiorowski (1962, 1985), it is possible to differentiate eleven zones of aptychi using four larger groups of aptychi, the lamellaptychi and laevaptychi and to a lesser degree the laevilamellaptychi and punctaptychi. Correlation between aptychi and ammonite zones still poses problems (A. Wierzbowski, personal communication 1998). Eliáš et al. (1996) also used aptychi ranges for biostratigraphy, but without a zonal subdivision; they preferred a multidisciplinary correlation method using the calpionellid subdivision as reference.

\section{Belemnites}

The most recent review of this fossil group is that of Doyle \& Bennett (1995) which includes a section on Middle and Upper Jurassic belemnite groups, including those of Europe. This publication presents a comprehensive review of the subject, including the work of Saks \& Nalnyaeva (1964, 1966), Riegraf (1980, 1981), Combémorel \& Mariotti (1986), and Doyle \& Kelly (1988); a range chart of the most useful taxa for biostratigraphy of the Middle and Upper Jurassic is included by Doyle \& Bennett (1995). The stratigraphic ranges of some more important Polish species have been published by Pugazewska (1988) and Malinowska (1997) and those of Sicily by Combémorel \& Mariotti (1990). Recently, Combémorel (1997) compiled all data available for the Tethys and the Boreal region of Europe and for each of them presented a correlation scheme with the subdivisions based on ammonites and belemnites; see also Hardenbol et al. (1998, chart 7). 


\section{Bivalves}

The most important group of bivalves for biostratigraphic purposes in the Upper Jurassic of Europe is the genus Buchia. In the Boreal regions of Eurasia and North America, it is of particular importance as a supplement to ammonites. The genus has been the focus of many papers in the last decades such as Zakharov (1981, 1987, 1990), Surlyk \& Zakharov (1982), Jeletzky (1984), Kelli (1990), Sey \& Kalacheva (1993b) and Sha \& Fürsich (1994). An interesting interpretation of the different ranges of Buchia species in America and Eurasia has been presented by Hoedemaker (1987). Stratigraphic range lists of selected bivalve species from Poland have been published by Karczewski \& Pugaczewska (1988) and Malinowska (1997).

A correlation chart that is mainly based on buchiid bivalves but also includes other bivalve genera (e.g. Retroceramus) has been compiled for northern Russia and the circum-Pacific regions by Damborenea et al. (1992). In the Upper Jurassic, the stratigraphic resolution of bivalve taxa, with the exception of buchiids, seems to be rather limited and/or needs further research (Damborena et al. 1992). For some regions, stratigraphic range lists of selected bivalve species have been published, for example for Poland (Malinowska 1997; Karczewski \& Pugaczewska 1998) and for northern Germany by Kaever et al. (1976).

\section{Gastropods}

The biostratigraphic resolution of this group in the Jurassic is not very high, but in special cases, when other guide fossils are not present, some representatives of the group may be used. An example from the Upper Jurassic of France (Nerineaceae) has been published recently by Barker (1994). Range lists of selected species from Poland have been published by Karczewski (1988) and Malinowska (1997).

\section{Brachiopods}

The most recent reviews of this group with respect to Upper Jurassic brachiopods are those of Ager (1994) and Alméras et al. (1991, 1994), especially for France and Britain, and Boullier \& Laurin (1997) for the Tethys and the 'Domaine NW européen français'. Ager (1994) considered the group within a global context. Alméras et al. (1994) discussed the facies dependence of brach- iopods, concluding that distinct zonal species of brachiopods are often necessary for different facies. For biostratigraphical purposes, it is possible to subdivide the Upper Jurassic of England and north-west France into nine zones and some subunits. The Polish species have been figured and described by Barczyk (1988); range charts are given in Malinowska (1997). Prozorovskaja (1993) presented an overview of the brachiopod subdivision of the Upper Jurassic of the southern part of the former USSR.

\section{Echinoderms}

To date, there is no subdivision scheme of the Upper Jurassic with respect to echinoderms. Some genera have biostratigraphic value; Saccocoma, for example, has been used in some multidisciplinary schemes. Thierry et al. (1997) presented range charts of the Upper Jurassic regular and irregular echinoid genera and species of France, with the expectation that with detailed research it would be possible to create a subdivision scheme comparable to that developed for the brachiopods of France.

\section{Corals (scleractinians)}

This group has poor biostratigraphic resolution. Its usefulness for stratigraphic purposes is therefore rather limited, also because of the close dependence of corals on ecological factors (Rosendahl 1988). Nevertheless, Beauvais (1988) subdivided the Upper Jurassic Series (except the Lower Oxfordian) into six zones based on madreporians (scleractinians). Polish species with range charts have been presented by Roniewicz \& Morycowa (1988) and range charts were published by Malinowska (1997).

\section{Sponges}

This fossil group is poorly suited to regional correlation, but some species may be useful for local subdivision; examples from France have been presented by Gaillard (1997).

\section{Vertebrate megafossils}

Jurassic vertebrate fossils are too scarce to be used as guide fossils. Nevertheless, if vertebrate remains are 
studied thoroughly, they frequently provide valuable biostratigraphic information (e.g. elasmobranchian teeth, Gramann et al. 1997). It should be mentioned that the Jurassic Period in Europe saw the early evolution of mammals, the flourishing of the first true birds and the first wave of the acme of the dinosaurs.

In other parts of the globe, vertebrates have been used for stratigraphy; in North America, for example, Turner \& Peterson (1998) subdivided the Upper Jurassic Morrison Formation into four biozones on the basis of dinosaurs, whereas in China, fish are used for subdivision (Chen 1990).

\section{Invertebrate microfossils}

\section{Foraminifera}

In the 1950-60s, foraminifera were one of the most important microfossil groups, together with ostracodes, for relative age determinations of marine sediments in boreholes; their importance has decreased in more recent times. Studies of foraminifera faunas from outcrops in southern Germany were reviewed by Groiss (1984). An account of epistominian zonation was given by Ascoli (1988), who also presented zonations and correlations between east Canadian offshore wells and the East European Platform (Grigelis \& Ascoli 1995). Foraminifera from northern Germany were presented by Klingler et al. (1962) and Gramann et al. (1997). The guide fossils and characteristic species of the Upper Jurassic foraminifera of Poland have been published by Bielecka (1988) and Styk (1997), those of the Russian Platform by A.Y. Azbel (in: Mesezhnikov 1989). Foraminifera of Sweden were studied by Norling (1972) and Guy-Ohlson \& Norling (1988). A short compilation of Upper Jurassic foraminifera in Britain has been published by Shipp \& Murray (1981), together with a range chart and figures of index species. The most recent reviews of foraminifera of Europe have been compiled by Ruget \& Nicollin (1997) on the small benthic forms, and by Bassoulet (1997a) on the large forms; see also Hardenbol et al. (1998, chart 7).

\section{Radiolaria}

This microfossil group, which has been the subject of much scientific research in recent years in Europe, is of particular importance in the Tethyan region. A comprehensive monograph was recently published by
Baumgartner et al. (1995) on the radiolarians of the Tethys, including a catalogue of all Tethyan species. The biochronological potential for subdividing the Upper Jurassic Series into 'Unitary Association Zones' (U.A.Z.) is well-demonstrated; there are six such zones covering the whole Upper Jurassic. They have a duration of between 2-6 Ma. This monograph demonstrates the significant advances in research into this group, especially if new quantitative concepts, such as the 'Unitary Association Zones', are applied to the biochronological subdivision of the Upper Jurassic.

Research into radiolarians and their stratigraphic potential has also been on the increase outside the Tethys, as demonstrated by recent publications concerning the Submediterranean province (Riegraf 1987; Kießling 1997; Zügel 1997; Zügel et al. 1998), and even the Subboreal and Boreal provinces, including the North Sea (Dyer \& Copestake 1989), the Russian Platform and the Barents Sea (Vishnevskaya 1993, 1997, 1998; Kozlova 1994). Dyer \& Copestake (1989) introduced a biozonation based on a succession of ten radiolarian events in the Kimmeridgian and Tithonian. Important attempts are also underway to correlate the new peri-Tethyan radiolarian assemblages with different micro- and macrofossil biozonations (Vishnevskaya \& De Wever 1997); owing to strong provincialism, direct correlation between the peri-Tethyan and Tethyan zonations is still very difficult, but has been undertaken recently (Hardenbol et al. 1998, chart 7).

\section{Ciliata}

This group is important only in the Tethyan region and the surrounding shelf deposits; the most comprehensive studies of the ciliata in recent years have been published as a result of the Sümeg meeting (Fülöp 1986; Remane et al. 1986). Polish forms have been reported by Nowak (1988) and those of Spain by Tavera et al. (1994) and Olóriz et al. (1995). Remane (1997, 1998) recently published informative reviews of the state-ofthe-art of the group, providing tables which include the stratigraphic succession of calpionellid species and the correlation of calpionellid, nannofossil and ammonite subdivisions with magnetostratigraphic events. Nearly simultaneously, Blau \& Grün (1997a, b) and Grün \& Blau $(1996,1997)$ proposed a revision of the calpionellid zonal and subzonal division. For the Tithonian Stage, they introduced and formally defined two zones and seven subzones; the duration of zones in the Jurassic 
is less than one million years, that of subzones about 300000 years.

Important results from the southern Tethyan margin have been contributed by Benzaggagh \& Atrops (1995, 1997). These workers provided precise correlation and species range charts for ammonites and calpionellids for the lower part of the calpionellid succession, which previously was poorly known, and clarified the succession of zones and subzones from the Middle Tithonian Semiformiceras fallauxi/Chitinoidella dobeni Subzone to the Upper Tithonian Durangites vulgaris/ Crassicollaria A3 Subzone. An important contribution on the calpionellid faunas of the southern and eastern Tethyan region of Europe was presented by Reháková \& Michalík (1997); the western Carpathians and their foreland in Moravia were treated by Řehánek (1990) and Reháková (1995, 2000). In all these last-mentioned publications, the Middle/Upper Tithonian boundary has apparently been drawn a little too high. Following the results of Benzaggagh \& Atrops (1995, 1997), this boundary lies between the Dobeni and Boneti Subzones of the Chitinoidella Zone and not above this zone.

\section{Ostracodes}

This group has a rather high stratigraphic resolution and has therefore been used frequently and successfully for the subdivision of sediments in northern Germany, Poland, England, the Netherlands, the North Sea Basin, France and Russia. In a recent monograph, Schudack (1994) revised the ostracodes of the Upper Jurassic in north-west Germany, documenting the correlation possibilities of this group in western, central and northern Europe. The Upper Jurassic of north-west Germany was subdivided into nineteen ostracode zones, representing variable durations (0.25-2.5 Ma; Schudack 1996a; Gramann et al. 1997). This study also presents a comprehensive list of all important publications on ostracodes. In northern Europe, the papers of Herngreen et al. (1988), Herngreen \& Wang (1989) and Guy-Ohlson \& Norling (1994) deal with this group in the Netherlands and Sweden, respectively. In Poland, Bielecka et al. (1988) treated the group, and range charts have been published by J. Szteijn (in: Marek \& Pajchlova 1997); Danish faunas were described by Christensen (1988). The most recent reviews of European ostracodes are those of Bodergat (1997) on marine ostracodes and Colin (1997) on non-marine ostracodes; see also Hardenbol et al. (1998, chart 7).

\section{Plant microfossils}

\section{Dinoflagellata}

Dinoflagellate cysts have become a widely used supplement to ammonites and are of particular importance in the subsurface. In a recent study, Poulsen (1996) emphasised the important role of dinoflagellates in Jurassic stratigraphy while comparing the Upper Jurassic of Denmark and Poland. The marine Upper Jurassic of Denmark was divided into seven zones and fifteen subzones whereas that of Poland was divided into four zones and twelve subzones (Poulsen 1996); the dinoflagellate cyst zonation of the Jurassic of Subboreal Europe is reviewed in Poulsen \& Riding (2003, this volume). In Great Britain, Riding \& Thomas (1992) have delivered the most recent compilation of dinoflagellates. Other important papers are those of Sarjeant (1979), Riley (1980), Riley \& Fenton (1982) and Riding \& Sarjeant (1984); one concerning Russia is that of Lentin \& Vozzhennikova (1990). In the Netherlands, Herngreen et al. (1988; see also Herngreen \& Wang 1989) presented a report on the stratigraphic bioevents based on the first and last appearance of dinoflagellate cyst species which made possible a subdivision into nine zones. In north-west Germany, the Oxfordian and Kimmeridgian has been subdivided into three dinoflagellate zones and eight subzones (Gramann et al. 1997). Detailed subdivisions for the Boreal and Tethyan regions have recently been published by Hardenbol et al. (1998, chart 7).

\section{Calcareous nannofossils \\ (coccoliths, nannolith groups)}

Recent advances in Jurassic calcareous nannofossil research have been reviewed by Bowen (1996), who dealt with several general aspects of this group, such as evolutionary succession, species diversity and longevity, distribution and provincialism, which are all important when regarding the utility of the group for biostratigraphic purposes. If conditions are favourable, then it is possible to subdivide the Upper Jurassic into five Boreal nannofossil zones (with six subzones) or three Submediterranean nannofossil zones (with seven subzones); correlation between these two regions is thus still problematic. The calcareous nannofossil bioevents were recently reviewed by Gardin (1997). Subdivisions and correlations for the Boreal/Subboreal 
and the Tethyan/Submediterranean Provinces can be found in Hardenbol et al. (1998, chart 7).

\section{Charophyaceae}

This group of calcareous algae has received new impetus with respect to its potential for biostratigraphy. In a recent publication, the results of a local zonal subdivision based on charophytes in the Lower Saxony Basin of north-west Germany (Schudack 1996b) has been correlated firstly with the new European Mesozoic charophyte biozonation (Riveline et al. 1996), secondly with the subdivisions of other microfossil groups in north-west Germany, such as ostracodes and dinocysts, and thirdly with the old micropalaeontological subdivisions for the Upper Jurassic (Malm) of north-west Germany (e.g. Klingler et al. 1962; Wick \& Wolburg 1962). In north-west Germany, from the Upper Oxfordian to the top of the Tithonian, five charophyte zones are now recognised, whereas in other parts of western Europe there are only three (Schudack 1991, 1993). The stratigraphic resolution of this group is not very high in the Upper Jurassic. Each biozone represents a duration of between 0.5 and over 2 million years. The Charophyaceae of western Europe have been revised in detail by Schudack (1993), and a useful compilation of all new data in Europe has been compiled by Riveline et al. (1996); see also Hardenbol et al. (1998, chart 7).

\section{Dasycladaceae}

This group seems to be only locally important for biostratigraphy (e.g. Portugal, Italy, Dinarids); a short review was presented by Bassoulet (1997b).

\section{Spores and pollen}

The value of pollen and spore grains for stratigraphic subdivision is not very high in the Upper Jurassic. The palynostratigraphy of Sweden (north-west Skåne) was discussed by Guy-Ohlson \& Norling (1988) in connection with a study of the microflora of some boreholes. It was revealed that "detailed correlation without the presence of dinoflagellates or other significant taxa appears difficult if not impossible" (Guy-Ohlson \& Norling 1988, p. 15). In the Central Graben of the southern North Sea, Upper Jurassic sediments were subdivided into four zones on the basis of sporomorphs
(Herngreen et al. 1988; Herngreen \& Wang 1989). In north-west Germany, the Upper Jurassic was divided into four zones using spores and pollen (Gramann et al. 1997).

The group apparently has its greatest importance at the system boundaries; it has been used successfully at the Triassic-Jurassic boundary and, to a lesser degree, at the Jurassic-Cretaceous boundary.

\section{Magnetostratigraphy}

This important method has become more directly applicable for stratigraphic purposes in the last few decades, especially when combined with radiometric and biostratigraphic data. Some of the more important papers on this topic are: (1) Mesozoic in general, Harland et al. (1990), Gradstein et al. (1995); (2) Upper Jurassic Lower Cretaceous, Ogg (1983), Ogg et al. (1984), Odin et al. (1994); (3) Oxfordian, Steiner et al. (1985), Ogg \& Steiner (1988a), Ogg et al. (1991), Ogg \& Coe (1998); (4) Oxfordian - Lower Kimmeridgian, Ogg \& Gutowski (1996); (5) Kimmeridgian-Tithonian, Ogg et al. (1994), (6) Jurassic-Cretaceous boundary, Ogg et. al. 1984), Ogg \& Lowrie (1986), Ogg \& Steiner (1988b), Ogg et al. (1991, 1994). In a recent publication on sequence chronostratigraphy of European Mesozoic basins, charts with magnetochronostratigraphic units have been compiled together with sequence chronostratigraphic and biochronostratigraphic data (Hardenbol et al. 1998, see below); the time span of the Upper Jurassic contains polarity chronozones M35 (upper part) - M19.

\section{Sequence chronostratigraphy}

Sequence stratigraphy is gaining in importance in chronostratigraphic correlation, as illustrated recently by the presentation of a framework for the European Mesozoic and Cenozoic basins (Hardenbol et al. 1998). Many data have been used and compiled in charts, two of which are important for the Upper Jurassic. They demonstrate the sequence chronostratigraphy (Sequences, T-R Facies Cycles, Major Transgressive-Regressive Cycles) for the Boreal and Tethyan realms combined with the ammonite biochronostratigraphy and magnetostratigraphy, plotted against the time scale.

The Upper Jurassic of Europe starts in the upper half of the transgressive part of the Second Major T-R Cycle (1st order cycle, named North Sea Cycle) in the Jurassic and ends within the regressive phase of this cycle. A 
total of 21 sequences (3rd order cycles) have been recognised (Ox 0-8, Ki 1-7, Ti 1-6) and three 2nd order T-R cycles (T8b-R10b) in the Boreal area, whereas the number in the Tethyan area is somewhat lower. A detailed overview of the North Sea Cycle in Europe (from the North Sea to south-east France) has been presented by Jacquin et al. (1998); marginal areas have been studied as follows: East Greenland (Surlyk 1991; 2003, this volume), Portugal, Lusitanian Basin (Leinfelder \& Wilson 1998), Portugal and Spain, South Iberian Margin (Olóriz et al. 1991), south-east France (Jan du Chêne et al. 2000), Switzerland (Gygi et al. 1998), West Carpathians (Reháková 2000) and Russia (Sahagian et al. 1996).

\section{Acknowledgements}

The author expresses his sincere thanks to Jon R. Ineson who kindly improved the English text and provided many useful suggestions. Two critical readers, Beris M. Cox and Andrzej Wierzbowski, contributed much to the advancement of this paper by their useful proposals and comments. Many colleagues helped with literature; in particular, I should like to mention Jean Guex, François Atrops, Elie Cariou, Raymond Enay, Reinhart Gygi, Vassili Mitta, Zdenek Vasicek and Andrzej Wierzbowski. Technical help has been provided by $\mathrm{F}$. Boehm, H. Forke, W. Kießling and E. Samankassou at Erlangen, and by the staff of the Geological Survey of Denmark and Greenland, to whom I express my thanks.

\section{References}

Ager, D.V. 1994: Brachiopod stratigraphy in the Jurassic. In: Cariou, E. \& Hantzpergue, P. (eds): 3rd International Symposium on Jurassic stratigraphy (Poitiers 1991). Geobios Mémoire Spécial 17, 57-68.

Aleynikov, A.N. \& Meledina, S.V. 1993: Ammonite biostratigraphy of the Middle and Upper Oxfordian in east Taimyr, east Siberia. Acta Geologica Polonica 43, 183-192.

Alkaya, F. 1989: Tithonian-Berriasian ammonite stratigraphy of the Nallihan (Ankara) area. Journal of the Faculty of Engineering and Architecture, Selçuk University 2, 1-13.

Alkaya, F. 1992: Kimmeridgian - Lower Tithonian ammonite fauna and stratigraphy of the Soğukçam (Bolu) area. Yerblimeri (Bulletin of Earth Sciences Application and Research Centre, Hacettepe University) 15, 55-73.

Alméras, Y., Bouillier, A. \& Laurin, B. 1991: Les zones de brachiopodes du Jurassique en France. Annales scientifiques Université Franche-Comté, Bésançon, Géologie 4(10), 3-30.
Alméras, Y., Bouillier, A. \& Laurin, B. 1994: La zonation du Jurassique français par les brachiopodes: limite de résolution. In: Cariou, E. \& Hantzpergue, P. (eds): 3rd International Symposium on Jurassic stratigraphy (Poitiers 1991). Geobios Mémoire Spécial 17, 69-77.

ANSSSR (ed.) 1974: Voprosy stratigrafii verchnej Jury. Materialy mezhdunarodnogo simpoziuma, Moskva 1967, 152 pp. (Problems of Upper Jurassic stratigraphy. Materials of the International Symposium, Moscow 1967.) Moscow: Geologitsheskij Institut Akademija Nauk SSSR (in Russian).

Arkell, W.J. 1941: The Upper Oxford Clay at Purton, Wilts., and the zones of the Lower Oxfordian. Geological Magazine $\mathbf{7 8}$ 161-172 and 316 only.

Arkell, W.J. 1956: Jurassic geology of the World, 806 pp. Edinburgh, London: Oliver \& Boyd.

Ascoli, P. 1988: Epistominid foraminiferal zonation of the MiddleLate Jurassic and earliest Cretaceous on the Canadian Atlantic shelf. In: Rocha, R.B. \& Soares, A.F. (eds): 2nd International Symposium on Jurassic stratigraphy (Lisbon 1987) 2, 649-668. Lisbon: Universidade Nova de Lisboa.

Atrops, F. 1982: La sous-famille des Ataxioceratinae (Ammonitina) dans le Kimméridgien inférieur du sud-est de la France. Documents des Laboratoires de Géologie Lyon 83, 463 pp.

Atrops, F. 1994: Présence d'ammonites du Tithonien inférieur des calcaires lithographiques de Canjuers (Var, France); conséquences stratigraphiques de Canjuers et paléogéographiques. Geobios Mémoire Spécial 16, 137-146.

Atrops, F. \& Meléndez, G. (eds) 1994a: 4th Oxfordian and Kimmeridgian Working Groups meeting, Lyon and south-eastern France basin, guide book and abstracts, $117 \mathrm{pp}$. Lyon: International Subcommission on Jurassic Stratigraphy.

Atrops, F. \& Meléndez, G. 1994b: The Oxfordian-Kimmeridgian boundary. In: Atrops, F. \& Meléndez, G. (eds): 4th Oxfordian and Kimmeridgian Working Groups meeting, Lyon and southeastern France basin, guide book and abstracts, 26-31. Lyon: International Subcommission on Jurassic Stratigraphy.

Atrops, F., Enay, R. \& Meléndez, G. 1993a: Joint meeting of the Oxfordian and Kimmeridgian Working Groups (Warsaw 1992). Acta Geologica Polonica 43, 158-168.

Atrops, F., Gygi, R., Matyja, B.A. \& Wierzbowski, A. 1993b: The Amoeboceras faunas in the Middle Oxfordian - lowermost Kimmeridgian, Submediterranean succession, and their correlation value. Acta Geologica Polonica 43, 213-227.

Aurell, M., Meléndez, G. \& Salas, R. 1990: The Oxfordian depositional sequence in the central and eastern Iberian chain (NE Spain). Publicaciones del Seminario de Paleontologia de Zaragoza 2, 85-118.

Barczyk, W. 1988: Type Brachiopoda. In: Malinowska, L. (ed.): Geology of Poland 3(2b), 268-275. Warsaw: Wydawnictwa Geologiczne.

Barker, M.J. 1994: The biostratigraphical potential of Nerineacean gastropods - case studies from the Middle Jurassic of England and the Upper Jurassic of France. In: Cariou, E. \& Hantzpergue, P. (eds): 3rd International Symposium on Jurassic stratigraphy (Poitiers 1991). Geobios Mémoire Spécial 17, 93-101.

Barthel, K.W. 1964: Die Verteilung der Cephalopoden in den 
Neuburger Bankkalken, ihr Vergleich mit der Ammonitenfauna von St. Concors und kurze Bemerkungen zum Zonenbegriff. In: Maubeuge, P.L. (ed.): Colloque du Jurassique à Luxembourg 1962, 513-517. Luxembourg: L'Institut Grand-Ducal.

Barthel, K.W. 1975: The Neuburg area (Bavaria, Germany) as a prospective reference region for the middle Tithonian. Mémoires du Bureau de Recherches Géologiques et Minières 86, 232-236.

Bassoulet, J.-P. 1997a: Les Grandes Foraminifères. In: Cariou, E. \& Hantzpergue, P. (eds): Biostratigraphie du Jurassique ouesteuropéen et méditerranéen: zonations parallèles et distribution des invertébrés et microfossiles. Bulletin du Centre Recherches Elf Exploration Production Mémoire 17, 293-304.

Bassoulet, J.-P. 1997b: Algues Dasycladales; distribution des principales éspèces. In: Cariou, E. \& Hantzpergue, P. (eds): Biostratigraphie du Jurassique ouest-européen et méditerranéen: zonations parallèles et distribution des invertébrés et microfossiles. Bulletin du Centre Recherches Elf Exploration Production Mémoire 17, 339-341.

Baumgartner, P.O., O'Dogherty, L., Gorican, S., Urquart, E., Pillevuit, A. \& De Wever, P. (eds) 1995: Middle Jurassic to Lower Cretaceous radiolaria of Tethys: occurrences, systematics, biochronology. Mémoires de Géologie (Lausanne) 23, 1173 pp.

Beauvais, L. 1988: Les zones de Madreporaires du Malm. In Rocha, R.B. \& Soares, A.F. (eds): 2nd International Symposium on Jurassic stratigraphy (Lisbon 1987) 2, 869-876. Lisbon: Universidade Nova de Lisboa.

Benzaggagh, M. \& Atrops, F. 1995: Les zones à Chitinoidella et à Crassicollaria (Tithonien) dans la partie interne du Prérif (Maroc). Données nouvelles et corrélation avec les zones d'ammonites. Comptes Rendus de l'Académie des Sciences (Paris) Série 2a 320, 227-234.

Benzaggagh, M. \& Atrops, F. 1997: Stratigraphie et associations de faune d'ammonites des zones du Kimméridgien, Tithonien et Berriasien basal dans le Prérif interne (Rif, Maroc). Newsletters on Stratigraphy 35, 127-163.

Bielecka, W. 1988: Order Foraminifera. In: Malinowska L. (ed.): Geology of Poland 3(2b), 215-237. Warsaw: Wydawnictwa Geologiczne.

Bielecka, W., Styck, O. \& Blaszyk, J. 1988: Class Ostracoda Latreille 1806. In: Malinowska, L. (ed.): Geology of Poland 3(2b), 359-376. Warsaw: Wydawnictwa Geologiczne.

Birkelund, T. \& Callomon, J.H. 1985: The Kimmeridgian ammonite faunas of Milne Land, central East Greenland. Bulletin Grønlands Geologiske Undersøgelse 153, 56 pp.

Birkelund, T. \& Pedersen, G.K. 1980: Middle Volgian ammonites and trace fossils from the Frederikshavn Member of the Bream Formation, northern Jutland. Danmarks Geologiske Undersøgelse Årbog 1979, 95-104.

Birkelund, T., Thusu, B. \& Vigran, J. 1978: Jurassic-Cretaceous biostratigraphy of Norway, with comments on the British Rasenia cymodoce zone. Palaeontology 21, 31-63.

Birkelund, T., Callomon, J.H., Clausen, C.K., Hansen, H.N. \& Salinas, I. 1983: The Lower Kimmeridgian Clay at Westbury, Wiltshire, England. Proceedings of the Geologists' Association (London) 94, 289-309.

Bischoff, G. \& Wolburg, J. 1963: Zur Entwicklung des Ober-Malm im Emsland. Erdöl-Zeitschrift 10, 445-472.
Blau, J. 1998: Monographie der Ammoniten des Obersinemuriums (Lotharingium, Lias) der Lienzer Dolomiten (Österreich): Biostratigraphie, Systematik und Paläobiogeographie. Révue de Paleobiologie 17, 177-285. Geneva: Museum d'Histoire Naturelle de Genève.

Blau, J. \& Grün, B. 1997a: Vorschlag zur Revision der Calpionellen Zonen und Subzonengliederung. Terra Nostra 97(6), 32-34.

Blau, J. \& Grün, B. 1997b: Late Jurassic/Early Cretaceous revised calpionellid zonal and subzonal division and correlation with ammonite and absolute time scales. Mineralia Slovaca 29, 297-300.

Blau, J. \& Meister, C. 2000: Upper Sinemurian ammonite successions based on 41 faunal horizons: an attempt at worldwide correlation. In: Hall, R.L. \& Smith, P.L. (eds): Advances in Jurassic research 2000. Proceedings of the 5th International Symposium on the Jurassic System. GeoResearch Forum 6, 3-12.

Bodergat, A.-M. 1997: Les ostracodes marins du Jurassique européen; utilisation stratigraphique. In: Cariou, E. \& Hantzpergue, P. (eds): Biostratigraphie du Jurassique ouest-européen et méditerranéen: zonations parallèles et distribution des invertébrés et microfossiles. Bulletin du Centre Recherches Elf Exploration Production Mémoire 17, 197-223.

Boullier, A. \& Laurin, B. 1997: Brachiopodes. Jurassique supérieur. In: Cariou, E. \& Hantzpergue, P. (eds): Biostratigraphie du Jurassique ouest-européen et méditerranéen: zonations parallèles et distribution des invertébrés et microfossiles. Bulletin du Centre Recherches Elf Exploration Production Mémoires 17, 184-189.

Bowen, P.R. 1996: Recent advances in Jurassic nannofossil research. In: Riccardi, A.C. (ed.): Advances in Jurassic research. GeoResearch Forum 1-2, 55-66.

BRGM 1974: Colloque du Jurassique à Luxembourg 1967. Mémoires du Bureau de Recherches Géologiques et Minières 75, 757 pp.

BRGM 1975: Colloque sur la Limite Jurassique-Cretacé, LyonNeuchâtel 1973. Mémoires du Bureau de Recherches Géologiques et Minières 86, 393 pp.

Callomon, J.H. 1965: Notes on Jurassic stratigraphical nomenclature. 7 th Congress of the Carpatho-Balkan Geological Association (Sofia 1965). Reports 2(1), 81-85. Sofia: CarpathoBalkan Geological Association.

Callomon, J.H. 1984a: Biostratigraphy, chronostratigraphy and all that - again! In: Michelsen, O. \& Zeiss, A. (eds): International Symposium on Jurassic stratigraphy (Erlangen 1984) 3, 611-624. Copenhagen: Geological Survey of Denmark.

Callomon, J.H. 1984b: The measurement of geological time. Proceedings of the Royal Institution of London 56, 65-99.

Callomon, J.H. 1984c: A review of the biostratigraphy of the postLower Bajocian ammonites of western and northern North America. In: Westermann, G.E.G. (ed.): Jurassic-Cretaceous biochronology and palaeogeography of northern America. Geological Association of Canada Special Paper 27, 143-174.

Callomon, J.H. 1988: The ammonite succession and subzones of the Transversarium zone in the submediterranean Middle Oxfordian. In: Rocha, R.B. \& Soares, A.F. (eds): 2nd International Symposium on Jurassic stratigraphy (Lisbon 1987) 1, 433-444. Lisbon: Universidade Nova de Lisboa.

Callomon, J.H. 1990: On the definition of the basal boundary stra- 
totype of the Jurassic Oxfordian stage. Publicaciones del Seminario de Paleontologia de Zaragoza 2, 119-128.

Callomon, J.H. 1994: Palaeontological methods of stratigraphy and biochronology: some introductory remarks. In: Cariou, E. \& Hantzpergue, P. (eds): 3rd International Symposium on Jurassic stratigraphy (Poitiers 1991). Geobios Mémoire Spécial 17, 16-30.

Callomon, J.H. 1995: Time from fossils: S.S. Buckman and Jurassic high-resolution geochronology. In: Le Bas, M.J. (ed.): Milestones in Geology. Geological Society Memoir (London) 16, 127-150.

Callomon, J.H. \& Birkelund, T. 1980: The Jurassic transgression and mid-late Jurassic succession in Milne Land, central East Greenland. Geological Magazine 117, 211-310.

Callomon, J.H. \& Birkelund, T. 1982: The ammonite zones of the Boreal Volgian (Upper Jurassic) in East Greenland. In: Embry, A.F. \& Balkwill, H.R. (eds): Arctic geology and geophysics. Canadian Society of Petroleum Geologists Memoir 8, 349-369.

Callomon, J.H. \& Cope, J.C.W. 1996: The Jurassic geology of Dorset. In: Taylor, P.D. (ed.): Field geology of the British Jurassic, 51-103. London: Geological Society.

Cariou, E. \& Hantzpergue, P. (eds) 1994: 3rd International Symposium on Jurassic stratigraphy (Poitiers 1991). Geobios Mémoire Spécial 17, 778 pp.

Cariou, E. \& Hantzpergue, P. (eds) 1997: Biostratigraphie du Jurassique ouest-européen et méditerranéen: zonations parallèles et distribution des invertébrés et microfossils. Bulletin du Centre Recherches Elf Exploration Production Mémoire 17, 422 pp.

Cariou, E. \& Meléndez, G. 1990: A modified perisphinctid zonation for the Middle Oxfordian of southern Europe Submediterranean Province. Publicaciones del Seminario de Paleontologia de Zaragoza 2, 129-152.

Cariou, E., Enay, R. \& Tintant, H. 1971: Oxfordien (sens subméditerranéenne). Compte Rendus sommaire des Séances de la Société géologique de France 1971. Fascicule 6, 18-21.

Cariou, E., Atrops, F., Hantzpergue, R., Enay, R. \& Rioult, M. 1991a: Oxfordien. In: 3rd International Symposium on Jurassic stratigraphy (Poitiers 1991). Résumés, 132 only.

Cariou, E., Meléndez, G. \& Branger, P. 1991b: Definition d'une échelle biochronologique fine pour une zone d'ammonites de l'Oxfordien moyen: zone à Transversarium (province subméditerranéenne). Comptes Rendus de l'Académie des Sciences (Paris) Série 2a 313, 703-708.

Cariou, E., Enay, R., Atrops, F., Hantzpergue, P., Marchand, D. \& Rioult, M. 1997: Oxfordien. In: Cariou, E. \& Hantzpergue, P. (eds): Biostratigraphie du Jurassique ouest-européen et méditerranéen: zonations parallèles et distribution des invertébrés et microfossiles. Bulletin du Centre Recherches Elf Exploration Production Mémoire 17, 79-86.

Casey, R. 1973: The ammonite succession at the JurassicCretaceous boundary in eastern England. In: Casey, R. \& Rawson, P.F. (eds): The Boreal Lower Cretaceous. Geological Journal Special Issue 5, 193-266.

CBGA 1965: VII Congress of the Carpatho-Balkan Geological Association (GBGA), 1-16 September 1965. Reports, Part 2, Stratigraphy, lithology and palaeontology 1, 342 pp., 2, 118 pp. Sofia: Bulgarian Academy of Sciences.
Cecca, F. 1990a: Etude des périsphinctidés de la zone à Darwini (Tithonique inférieur) des Apennins des Marches (Italie): paléontologie et paléobiogéographie. In: Pallini, G. et al. (eds): Atti II ${ }^{\circ}$ Convegno Internazionale 'Fossili, Evoluzione, Ambiente' (Pergola 1987), 39-55.

Cecca, F. 1990b: 'Subplanitoides' mediterraneus, nuove specie di Perisphinctide (Ammonitina) della Zona a Semiforme (Titonico inferiore) della provincia mediterranea. In: Pallini, G. et al. (eds): Atti II ${ }^{\circ}$ Convegno Internazionale 'Fossili, Evoluzione, Ambiente' (Pergola 1987), 57-62.

Cecca, F. \& Santantonio, M. 1988: Kimmeridgian and Lower Tithonian ammonite assemblages in the Umbria-MarchesSabine Apennine (central Italy). In: Rocha, B.R. \& Soares, A.F. (eds): 2nd International Symposium on Jurassic stratigraphy (Lisbon 1987) 1, 525-542. Lisbon: Universidade Nova de Lisboa.

Cecca, F., Cresta, S., Pallini, G. \& Santantonio, M. 1986: Biostratigrafia ed ammoniti des Dogger-Malm di Colle Tordina (Monti della Rossa, Appennino marchigiano). Bolletino del Servizio Geologico d'Italia 104, 177-204.

Cecca, F., Enay, R. \& Le Hégarat, G. 1989a: The Tithonian of Ardèche (south-east France): new stratigraphical data and revision of the type-section of the 'Ardescian' (Toucas 1890). Newsletters on Stratigraphy 20, 115-129.

Cecca, F., Enay, R. \& Le Hégarat, G. 1989b: L’Ardescien (Tithonique supérieur) de la région stratotypique: Séries de réferénce et faunes (ammonites, calpionelles) de la bordure ardéchoise. Documents des Laboratoires de Géologie Lyon 107, 115 pp.

Chen, P.-J. 1990: Distribution and migration of the Jahol fauna with reference to the non-marine Jurassic/Cretaceous boundary in China. In: Menner, V.V. (ed.): Granica Jury i Mela. Akademija Nauk SSSR, Sibirskoe otdelenie, Instituta Geologii i Geofiziki Trudy 699, 78-85, 190 only (in Russian with English title).

Choffat, P. 1885: Description de la faune jurassique du Portugal. Mollusques Lamellibranches, 2 me ordre. Asiphonidae. Mémoire Direction des Travaux Geologiques en Portugal, 76 pp.

Christensen, O.B. 1988: Ostracod zones and dispersion of Mesozoic fossils in the Scandinavian North Sea area. In: Hanai, T., Ikeya, N. \& Ishizaki, K. (eds): Evolutionary biology of Ostracoda: its fundamentals and applications. Developments in Paleontology and Stratigraphy 11, 1269-1281.

Colin, J.-P. 1997: Les Ostracodes limniques du Jurassique européen. In: Cariou, E. \& Hantzpergue, P. (eds): Biostratigraphie du Jurassique ouest-européen et méditerranéen: zonations parallèles et distribution des invertébrés et microfossiles. Bulletin du Centre Recherches Elf Exploration Production Mémoire 17, 273-279.

Combémorel, R. 1997: Bélemnites. In: Cariou, E. \& Hantzpergue, P. (eds): Biostratigraphie du Jurassique ouest-européen et méditerranéen: zonations parallèles et distribution des invertébrés et microfossiles. Bulletin du Centre Recherches Elf Exploration Production Mémoire 17, 157-168.

Combémorel, R. \& Mariotti, N. 1986: Les bélemnites de la carrièrre de Serra San Quirico (Province d'Ancona, Appenin central, Italie) et la paléobiogéographie des bélemnites de la Téthys méditerranéenne au Tithonique inférieur. Geobios 19, 299-321.

Combémorel, R. \& Mariotti, N. 1990: Taxonomic and biostrati- 
graphic remarks on Tithonian belemnites from Sicily. In: Pallini, G. et al. (eds): Atti $\mathrm{II}^{\circ}$ Convegno Internazionale: 'Fossili, Evoluzione, Ambiente' (Pergola 1987), 207-219.

Cope, J.C.W. 1967: The palaeontology and stratigraphy of the lower part of the Upper Kimmeridge clay of Dorset. Bulletin of the British Museum (Natural History) Geology Series 15(1), 79 pp.

Cope, J.C.W. 1978: The ammonite faunas of the upper part of the Upper Kimmeridge Clay of Dorset. Palaeontology 21, 469-533.

Cope, J.C.W. [with contributions by Callomon, J.H.] 1980: Kimmeridgian correlation chart. In: Cope, J.C.W. et al.: A correlation of Jurassic rocks in the British Isles. Part Two: Middle and Upper Jurassic. Geological Society Special Report (London) 15, 76-85.

Cope, J.C.W. 1993: The Bolonian stage: an old answer to an old problem. Newsletters on Stratigraphy 28, 151-156.

Cope, J.C.W. \& Zeiss, A. 1964: Zur Parallelisierung des englischen Oberkimmeridge mit dem fränkischen Untertithon (Malm $\zeta$ ). Geologische Blätter für Nordost-Bayern und angrenzende Gebiete 14, 5-14.

Cope, J.C.W., Duff, K.L., Parsons, C.F., Torrens, H.S., Wimbledon, W.A. \& Wright, J.K. 1980: A correlation of Jurassic rocks in the British Isles. Part Two: Middle and Upper Jurassic. Geological Society Special Report (London) 15, 109 pp.

Corna, M., Dommergues, J.L., Meister, C. \& Page, K. 1997: Les faunes d'ammonites du Jurassique inférieur (Hettangien, Sinémurien et Pliensbachien) au nord du Massif des Écrins (Oisans, Alpes occidentales françaises). Revue de Paleobiologie 16, 321-409.

Cowie, J.W., Ziegler, W., Boucot, A.J., Bassett, M.G. \& Remane, J. 1986: Guidelines and statutes of the International Commission on Stratigraphy (ICS). Courier Forschungsinstitut Senckenberg 83, $1-14$.

Cox, B.M. \& Gallois, R.W. 1981: The stratigraphy of the Kimmeridge Clay of the Dorset type area and its correlation with some other Kimmeridgian sequences. Institute of Geological Sciences Report 80(4), 44 pp.

Cox, B.M. \& Richardson, G. 1982: The ammonite zonation of Upper Oxfordian mudstones in the Vale of Pickering, Yorkschire. Proceedings of the Yorkshire Geological Society 44, 53-58.

Damborenea, S.E., Polubotko, I.V., Sey, I.I. \& Paraketsov, K.V. 1992: Bivalve zones and assemblages of the Circum-Pacific region. In: Westermann, G.E.G. (ed.): The Jurassic of the Circum-Pacific. World and Regional Geology 3, 300-307. Cambridge: Cambridge University Press.

Dimke, M. \& Zeiss, A. 1997: Die Hangenden Bankkalke östlich von Liptingen (Unter-Tithon, südwestliche Schwäbische Alb) - Stratigraphie, Faziesübersicht und neue Fossilfunde. Geologische Blätter für Nordost-Bayern und angrenzende Gebiete 47, 71-98.

Doben, K. \& Heller, F. 1968: Erläuterungen zur geologischen Karte 1:25 000, Blatt Nr. 6637 Rieden, 56 pp. München: Bayerisches Geologisches Landesamt.

Dommergues, J.-L. 1997: Le Jurassique inférieur. In: Cariou, E. \& Hantzpergue, P. (eds): Biostratigraphie du Jurassique ouesteuropéen et méditerranéen: zonations parallèles et distribu- tion des invertébrés et microfossiles. Bulletin du Centre Recherches Elf Exploration Production Mémoire 17, 347-353.

Donovan, D.T., Callomon, J.H. \& Howarth, M.K. 1981: Classification of the Jurassic Ammonitina. In: House, M.R. \& Senior, J.R. (eds): The Ammonoidea; the evolution, classification, mode of life and geological usefulness of a major fossil group. Systematics Association Special Volume 18, 101-155.

Doyle, P. \& Bennett, M. 1995: Belemnites in biostratigraphy. Palaeontology 38, 815-829.

Doyle, P. \& Kelly, S.R.A. 1988: The Jurassic and Cretaceous belemnites of Kong Karls Land, Svalbard. Norsk Polarinstitutt Skrifter 189, $77 \mathrm{pp}$.

Durand, D.M. \& Gąsiorowski, S.M. 1970: Les niveaux à Aptychus dans les pays autour de la Méditerranée occidentale et dans les Carpathes. Comptes Rendus de l'Académie des Sciences (Paris) Série D 270, 767-770.

Dyer, R. \& Copestake, P. 1989: A review of Late Jurassic to earliest Cretaceous radiolaria and their biostratigraphic potential to petroleum exploration in the North Sea. In: Batten, D.J. \& Keen, M.C. (eds): Northwest European micropalaeontology and palynology, 214-235. British Micropalaeontological Society Series. Chichester: Ellis Horwood.

Eliáš, M., Martinec, P., Reháková, D. \& Vašǐček, Z. 1996: Geology and stratigraphy of the Kurovice Limestone and Tlumačov Marl Formation at the Kurovice quarry (Upper Jurassic - Lower Cretaceous, outer western Carpathians, Czech Republic). Věstník českého geologického ústavu 71, 259-275.

Enay, R. 1963: Contribution à l'étude paléontologique de l'oxfordien supérieur de Trept (Isère). I. Stratigraphie et ammonites. Travaux de Laboratoire de Géologie Lyon $\mathbf{8}, 7-81$.

Enay, R. 1966: L’oxfordien dans la moitié sud du Jura français: etude stratigraphique. Nouvelles archives du Muséum d'Histoire naturelle de Lyon 8(1), 310 pp.

Enay, R. 1972: Paléobiogéographie des ammonites du Jurassique terminal (Tithonique/Volgien/Portlandien sensu lato) et mobilité continentale. Geobios 5, 355-407.

Enay, R. 1980a: Séquanien. Mémoires du Bureau de Recherches Géologiques et Minières 109, 87-89.

Enay, R. 1980b: Crussolien. Mémoires du Bureau de Recherches Géologiques et Minières 109, 90-91.

Enay, R. 1997: Le Jurassique supérieur. In: Cariou, E. \& Hantzpergue, P. (eds): Biostratigraphie du Jurassique ouest-européen et méditerranéen: zonations parallèles et distribution des invertébrés et microfossiles. Bulletin du Centre Recherches Elf Exploration Production Mémoire 17, 363-369.

Enay, R. \& Geyssant, J.R. 1975: Faunes tithoniques des chaînes bétiques (Espagne méridionale). Mémoires du Bureau de Recherches Géologiques et Minières 86, 39-55.

Enay, R. \& Meléndez, G. 1984: Report of the Oxfordian Working Group. In: Michelsen, O. \& Zeiss, A. (eds): International Symposium on Jurassic stratigraphy (Erlangen 1984) 1, 87-103. Copenhagen: Geological Survey of Denmark.

Enay, R., Contini, D. \& Bouillier, A. 1988: Le Séquanien-type de Franche-Comté (Oxfordien supérieur): datations et correlations nouvelles, conséquences sur la paléogéographie et l'évolution du Jura et régions voisines. Eclogae Geologicae Helvetiae 81, 295-363. 
Enay, R., Bernier, G., Barale, J.P., Buffetaut, E., Gaillard, C., Gall, J.C. \& Wenz, S. 1994: Les ammonites des calcaires lithographiques de Cerin (Ain, France): stratigraphie et taphonomie. Geobios Mémoire Spécial 16, 25-36.

Enay, R., Boughdiri, M. \& Le Hégarat, G. 1998a: Durangites, Protacanthodiscus (Ammonitina) et formes voisines du Tithonien supérieur - Berriasien dans la Téthys méditérranéenne (SE France, Espagne, Algérie et Tunisie). Comptes Rendus de l'Académie des Sciences (Paris), Sciences de la terre et des planètes 327, 425-430.

Enay, R., Boughdiri, M. \& Le Hégarat, G. 1998b: Toucasiella gen. nov., Himalayitidae (Ammonitina) nouveau du Tithonien supérieur: origine de Durangites. Comptes Rendus de l'Académie des Sciences (Paris), Sciences de la terre et des planètes 327, 471-477.

Fischer, R. 1991: Die Oberjura-Schichtfolge vom Langenberg bei Oker. Arbeitskreis Paläontologie Hannover 19, 21-34.

Fortwengler, D. \& Marchand, D. 1994a: Nouvelles unités biochronologiques de la zone à Mariae (Oxfordien inférieur). In: Cariou, E. \& Hantzpergue, P. (eds): 3rd International Symposium on Jurassic stratigraphy (Poitiers 1991). Geobios Mémoire Spécial 17, 203-209.

Fortwengler, D. \& Marchand, D. 1994b: The Savournon section: Upper Callovian (Lamberti Zone) to Lower Oxfordian (Mariae Zone) under 'Terre Noires' facies. In: Atrops, F. \& Meléndez, G. (eds): 4th Oxfordian and Kimmeridgian Working Groups meeting, guide book and abstracts, 95-99.

Fortwengler, D. \& Marchand, D. 1994c: The Thuoux section: Callovian-Oxfordian boundary (Lamberti to Mariae Zone) under 'Terre Noires' facies. In: Atrops, F. \& Meléndez, G. (eds): 4th Oxfordian and Kimmeridgian Working Groups meeting, guide book and abstracts, 103-106.

Fortwengler, D., Marchand, D. \& Bonnot, A. 1995: Ammonites and Callovian-Oxfordian boundary in the 'Terre Noires' from Diois (south-eastern basin, France); examples of Thuoux and Savournon sections. International Subcommission on Jurassic Stratigraphy Newsletter 23, 106 only.

Fortwengler, D., Marchand, D. \& Bonnot, A. 1997: Les coupes de Thuoux et de Savournon (SE de la France) et la limite Callovien-Oxfordien. Geobios 30, 519-540.

Fözy, I. 1988: Tithonian ammonites (Oppeliidae, Haploceratidae and Simoceratidae) from the Transdanubian Central Range, Hungary. Annales Universitatis Scientiarum Budapestinensis de Rolando Eötvös nominatae. Sectio Geologica 28, 43-119.

Fözy, I. 1993: Upper Jurassic ammonite biostratigraphy in the Geresce and Pilis Mountains. (Transdanubian Central Range, Hungary). Földtani Közlöny 123, 441-464.

Fözy, I. \& Meléndez, G. 1996: Oxfordian ammonites from Hungary. GeoResearch Forum 1-2, 187-194.

Fözy, I., Kázmér, M. \& Szente, I. 1994: A unique Lower Tithonian fauna in the Geresce Mountains, Hungary. In: Pallini, G. (ed.): Proceedings of the 3rd Pergola International Symposium 'Fossili, Evoluzione, Ambiente'. Palaeopelagos Special Publication 1, 155-166. Rome: Università 'La Sapienza'.

Fülöp, J. (ed.): 1986: Meeting of the Working Group for the Jurassic-Cretaceous boundary, Sümeg/Hungary 1984. Acta Geologica Hungarica 29, 168 pp.
Gaillard, C. 1997: Intérêt biostratigraphique de quelques éponges silicieuses dans le Jurassique supérieur Français. In: Cariou, E. \& Hantzpergue, P. (eds): Biostratigraphie du Jurassique ouest-européen et méditerranéen: zonations parallèles et distribution des invertébrés et microfossiles. Bulletin du Centre Recherches Elf Exploration Production Mémoire 17, 331-337.

Gardin, S. 1997: Les bioévénements à nannofossils calcaires. In: Cariou, E. \& Hantzpergue, P. (eds): Biostratigraphie du Jurassique ouest-européen et méditerranéen: zonations parallèles et distribution des invertébrés et microfossiles. Bulletin du Centre Recherches Elf Exploration Production Mémoire 17, 305-329.

Gąsiorowski, S.M. 1962: Aptychi from the Dogger, Malm and Neocomian in the western Carpathians and their stratigraphical value. Studia Geologica Polonica 10, 144 pp.

Gąsiorowski, S.M. 1985: Sur les zones à Aptychus du Monde. 8th Congress of the Carpatho-Balkan Geological Association Report 1, 32-35. Kraków: Carpatho-Balkan Geological Association.

Gerasimov, P.A. \& Mikhailov, N.P. 1966: Volzhskij jarus i edinaja stratigrafitsheskaja shkala verchnogo otdela jurskoj sistemy. (Volgian stage and the geostratigraphical scale for the upper series of the Jurassic System.) Izvestija Akademii Nauk SSSR, Serija geologitsheskaja 1966(2), 118-138 (in Russian).

Gerasimov, P.A., Mitta, V.V. \& Kotchanova, M.D. 1995: Iskopaemye volzhskogo jarusa Zentralnoj Rossii, 116 pp. (Fossils of the Volgian stage of Central Russia.) Moscow: Vserossijskij naytschno-issledovatelskij geologitsheskij neftjanoj institut (VNIGNI) et Moskovskaja Gorodskaja stanzija junych naturalistov (MosGorSJUN) (in Russian).

Geyer, O.F. 1961: Monographie der Perisphinctidae des unteren Unterkimmeridgium (Weißer Jura $\gamma$, Badener Schichten) im süddeutschen Jura. Palaeontographica A 117, 157 pp.

Geyssant, J.R. 1994: Colonisation par des ammonites méridionales des mers subboréales kimméridgiennes du Yorkshire (Angleterre). In: Cariou, E. \& Hantzpergue, P. (eds): 3rd International Symposium on Jurassic stratigraphy (Poitiers 1991). Geobios Mémoire Spécial 17, 245-254.

Geyssant, J.R. 1997: Tithonien. In: Cariou, E. \& Hantzpergue, P. (eds): Biostratigraphie du Jurassique ouest-européen et méditerranéen: zonations parallèles et distribution des invertébrés et microfossiles. Bulletin du Centre Recherches Elf Exploration Production Mémoire 17, 97-102.

Geyssant, J.R. \& Enay, R. 1991: Tithonique. In: 3rd International Symposium on Jurassic stratigraphy (Poitiers 1991). Résumés, 134 only.

Geyssant, J.R., Vidier, J.-P., Herbin, J.-P., Proust, J.N. \& Deconinck, J.-F. 1993: Biostratigraphie et paléoenvironnement des couches de passage Kimméridgien/Tithonien du Boulonnais (Pas-deCalais): nouvelles données paléontologiques (ammonites), organisation séquentielle et contenu en matière organique. Géologie de la France 4, 11-24.

Glowniak, E., Matyja, B.A., Poulsen, N.E. \& Wierzbowski, A. 1997: Oxfordian (Jurassic) Meeting in Poland (May 1997). International Subcommission on Jurassic Stratigraphy Newsletter 25, 44-46.

Gradstein, F.M., Agterberg, F.P., Ogg, J.G., Hardenbol, J., van Veen, P., Thierry, J. \& Huang, Z. 1994: A Mesozoic time scale. 
Journal of Geophysical Research 99, 24051-24074.

Gradstein, F.M., Agterberg, F.P., Ogg, J.G., Hardenbol, J., van Veen, P., Thierry, J. \& Huang, Z. 1995: A Triassic, Jurassic and Cretaceous time scale. In: Berggren, W.A. et al. (eds): Geochronology, time scales and global stratigraphic correlation. SEPM (Society for Sedimentary Geology) Special Publication 54, 95-126.

Gramann, F. et al. 1997: Das Niedersächsische Oberjura-Becken - Ergebnisse interdisziplinärer Zusammenarbeit. Zeitschrift der Deutschen Geologischen Gesellschaft 148, 165-236.

Greppin, J.B. 1867: Essai géologique sur le Jura suisse, 152 pp. Delémont: Helg \& Boéchat.

Grigelis, A. \& Ascoli, P. 1995: Middle Jurassic - Early Cretaceous foraminiferal zonation and paleoecology of offshore eastern Canada and the East European Platform. Geological Survey of Canada Open File Report 3099, 25 pp.

Groiss, J.T. 1984: Micropaleontological investigation of the Franconian Jurassic. In: Michelsen, O. \& Zeiss, A. (eds): International Symposium on Jurassic stratigraphy (Erlangen 1984) 3, 662-672. Copenhagen: Geological Survey of Denmark.

Groiss, J.T., Haunschild, H. \& Zeiss, A. 2000: Das Ries und sein Vorland. Sammlung Geologischer Führer 92, 271 pp. BerlinStuttgart: Gebrüder Borntraeger.

Gröschke, M. 1985: Stratigraphie und Ammonitenfauna der Jurarelikte zwischen Straubing und Passau (Niederbayern). Palaeontographica A 191, 68 pp.

Grün, B. \& Blau, J. 1996: Phylogenie, Systematik und Biostratigraphie der Calpionellidae Bonet, 1956: Neue Daten aus dem Rosso Ammonitico Superiore und dem Biancone (Oberjura/Unterkreide: Tithon-Valangin) von Ra Stua (Prov. Belluno, Italien). Revue de Paléobiologie 15, 571-595.

Grün, B. \& Blau, J. 1997: New aspects of calpionellid biochronology: proposal for a revised calpionellid zonal and subzonal division. Revue de Paléobiologie 16, 197-214.

Guy-Ohlson, D. \& Norling, E. 1988: Upper Jurassic litho- and biostratigraphy of NW Scania, Sweden. Sveriges Geologiska Undersökning Serie Ca 72, 37 pp.

Guy-Ohlson, D. \& Norling, E. 1994: Jurassic sequences in Sweden. In: Cariou, E. \& Hantzpergue, P. (eds): 3rd International Symposium on Jurassic stratigraphy (Poitiers 1991). Geobios Mémoire Spécial 17, 275-286.

Gygi, R.A. 1977: Revision der Ammonitengattung Gregoryceras (Aspidoceratidae) aus dem Oxfordian (Oberer Jura) der Nordschweiz und von Süddeutschland. Taxonomie, Phylogenie, Stratigraphie. Eclogae Geologicae Helvetiae 70, 435-542.

Gygi, R.A. 1986: Eustatic sea level changes of the Oxfordian (Late Jurassic) and their effect documented in sediments and fossil assemblages of an epicontinental sea. Eclogae Geologicae Helvetiae 79, 455-491.

Gygi, R.A. 1990a: The Oxfordian ammonite succession near Liesberg BE and Péry BE, northern Switzerland. Eclogae Geologicae Helvetiae 83, 177-199.

Gygi, R.A. (ed.) 1990b: 2nd Oxfordian Working Group meeting, Basel and Jura range of northern Switzerland 1990, 70 pp. Basel: International Subcommission on Jurassic Stratigraphy.

Gygi, R.A. 1995: Datierung von Seichtwassersedimenten des Späten Jura in der Nordwestschweiz mit Ammoniten. Eclogae
Geologicae Helvetiae 88, 1-58.

Gygi, R.A. 2000a: Integrated stratigraphy of the Oxfordian and Kimmeridgian (Late Jurasic) in northern Switzerland and adjacent southern Germany. Denkschriften der Schweizerischen Akademie der Naturwissenschaften 104, 119 pp.

Gygi, R.A. 2000b: Annotated index of lithostratigraphic units currently used in the Upper Jurassic of northern Switzerland. Eclogae Geologicae Helvetiae 93, 125-146.

Gygi, R.A. 2000c: Zone boundaries and subzones of the Transversarium Ammonite Zone (Oxfordian, Late Jurassic) in the reference section of the zone, northern Switzerland. GeoResearch Forum 6, 77-84

Gygi, R.A. \& Marchand, D. 1982: Les faunes de Cardioceratinae (Ammonoidea) du Callovien terminal et de l'oxfordien inférieur et moyen (Jurassique) de la Suisse septentrionale: stratigraphie, paléoécologie, taxonomie préliminaire. Geobios 15, 517-571.

Gygi, R.A. \& Persoz, F. 1986: Mineralostratigraphy, litho- and biostratigraphy combined in correlation of the Oxfordian (Late Jurassic) formations of the Swiss Jura range. Eclogae Geologicae Helvetiae 79, 385-454.

Gygi, R.A., Coe, A.L. \& Vail, P.R. 1998: Sequence stratigraphy of the Oxfordian and Kimmeridgian stages (Late Jurassic) in northern Switzerland. In: de Graciansky, P.-C. et al. (eds): Mesozoic and Cenozoic sequence stratigraphy of European basins. SEPM (Society for Sedimentary Geology) Special Publication 60, 527-544.

Hahn, W. 1963: Die Gattung Gravesia Salfeld (Ammonoidea) im Oberjura Mittel- und Nordwesteuropas. Palaeontographica A 106, 90-110.

Hall, R.L. \& Smith, P.L. (eds) 2000: Advances in Jurassic research 2000. Proceedings of the 5th International Symposium on the Jurassic System. GeoResearch Forum 6, 545 pp.

Hantzpergue, P. 1979: Biostratigraphie du Jurassique supérieur nord-aquitain. Bulletin de la Société géologique de France 21, 715-725.

Hantzpergue, P. 1989: Les ammonites kimméridgiennes du hautfond d'Europe occidentale: biochronologie, systématique, évolution, paléobiogéographie. CNRS (ed.): Cahiers de Paléontologie, 428 pp. Paris: Centre National de la Recherches Scientifique (CNRS).

Hantzpergue, P., Atrops, F. \& Enay, R. 1991: Kimméridgien. In: 3rd International Symposium on Jurassic stratigraphy (Poitiers 1991). Résumés, 133 only.

Hantzpergue, P., Atrops, F. \& Enay, R. 1997: Kimméridgien. In: Cariou, E. \& Hantzpergue, P. (eds): Biostratigraphie du Jurassique ouest-européen et méditerranéen: zonations parallèles et distribution des invertébrés et microfossiles. Bulletin du Centre Recherches Elf Exploration Production Mémoire 17, 87-96.

Hantzpergue, P., Baudin, F., Mitta, V., Olferiev, A. \& Zakharov, V. 1998: Le Jurassique supérieur du bassin de la Volga: biostratigraphie des faunes d'ammonites et corrélations avec les zonations standards européennes. Comptes Rendus de l'Académie des Sciences (Paris). Sciences de la terre et des planètes 326, 633-640.

Hardenbol, J., Thierry, J., Farley, M.B., Jacquin, T., de Graciansky, 
P.-C. \& Vail, P.R. 1998: Mesozoic and Cenozoic sequence chronostratigraphic framework of European basins. In: de Graciansky, P.-C. et al. (eds): Mesozoic and Cenozoic sequence stratigraphy of European basins. SEPM (Society for Sedimentary Geology) Special Publication 60, 3-13.

Harland, W.B., Armstrong, R.L., Cox, A.V., Craig, L.E., Smith, A.G. \& Smith, D.G. 1990: A geologic time scale 1989, 263 pp. Cambridge: Cambridge University Press.

Haug, E. 1910: Traité de Géologie, 2. Les periodes géologiques. Fasc. 2, Jurassique et Crétacé, 929-1396. Paris: Colin.

Heller, F. 1964: Ammoniten aus dem oberen Malm Gamma bei Theuern und Lengenfeld (Opf.). Geologische Blätter für Nordost-Bayern und angrenzende Gebiete 14, 144-147.

Herngreen, G.F.W. \& Wong, T.E. 1989: Revision of the 'Late Jurassic' stratigraphy of the Dutch Central North Sea Graben. Geologie en Mijnbouw 67, 73-105.

Herngreen, G.F.W., Lissenberg, T. \& Witte, L.J. 1988: Dinoflagellate, sporomorph and micropaleontological zonation of Callovian to Ryazanian strata in the Central North Sea Graben, the Netherlands. In: Rocha, R.B. \& Soares, A.F. (eds): 2nd International Symposium on Jurassic stratigraphy (Lisbon 1987) 2 , 745-762. Lisbon: Universidade Nova de Lisboa.

Hoedemaker, P.J. 1987: Correlation possibilities around the Jurassic/Cretaceous boundary. Scripta Geologica 84, 55 pp.

Hoedemaker, P.J. 1990: The Neocomian boundaries of the Tethyan realm based on the distribution of ammonites. Cretaceous Research 11, 331-342.

Hoedemaker, P.J. 1991: Tethyan-Boreal correlations and the Jurassic-Cretaceous boundary. Newsletters on Stratigraphy 25, 37-60.

Hoedemaker, P.J. 1994: The Berriasian stage: a review. Géologie Alpine Mémoire 20, 5-14.

Ilovajskij, D.I. \& Florenskij, K.P. 1941: Verchnejurskie ammonity bassejnov rek Yrala i Ileka. (Les ammonites du jura supérieur des bassins des rivières Oural et Ilek.) Matererialy k poznaniju geologitsheskogo stroenija SSSR, Novaja Serija, Vypusk (Moscow) 1(5), 1-196 (in Russian with extended French summary).

Jacquin, T., Dardeau, G., Durlet, C., de Graciansky, P.-C. \& Hantzpergue, P. 1998: The North Sea Cycle: an overview of 2nd order transgressive/regressive facies cycles in western Europe. In: de Graciansky, P.-C. et al. (eds): Mesozoic and Cenozoic sequence stratigraphy of European basins. SEPM (Society for Sedimentary Geology) Special Publication 60, 445-466.

Jan du Chêne, R., Atrops, F., Emmanuel, L., de Rafélis, M. \& Renard, M. 2000: Palynology, ammonites and sequence stratigraphy from Tethyan middle Oxfordian to Lower Kimmeridgian, S-E France. Comparison with the Boreal Realm. Bulletin du Centre Recherches Elf Exploration Production 22, 273-321.

Jeletzky, J.A. 1984: Jurassic-Cretaceous boundary beds of Western and Arctic Canada and the problem of the Tithonian-Berriasian stages in the Boreal realm. Geological Association of Canada Special Paper 27, 175-255.

Jeletzky, J.A. 1989: Age of the Neuburg Formation (Bavaria, Federal Republic of Germany) and its correlation with the Subboreal Volgian and Mediterranean Tithonian. Newsletters on Stratigraphy 20, 149-169.

Kaever, M., Oekentorp, K. \& Siegfried, P. 1976: Fossilien Westfalens; Invertebraten des Jura. Münstersche Forschungen zur Geologie und Palaeontologie 40/41, 1-360.

Karczewski, L. 1988: Class Gastropoda Cuvier, 1797. In: Malinowska, L. (ed.): Geology of Poland 3(2b), 296-312. Warsaw: Wydawnictwa Geologiczne.

Karczewski, L. \& Pugaczewska, H. 1988: Class Bivalvia (Buonanni 1681) Linné 1785. In: Malinowska, L. (ed.): Geology of Poland 3(2b), 276-296. Warsaw: Wydawnictwa Geologiczne.

Kejsi [Casey], R. \& Mesezhnikov, M.S. 1986: Verchnie gorizonty srednevolzhskogo podjarusa i ich anglijskie ekvivalenty. (Upper horizons of the Middle Volgian Substage and their equivalents in England.) Izvestija Akademii Nauk SSSR, Serija geologitsheskaja 1986(10), 69-81 (in Russian).

Kejsi [Casey], R., Mesezhnikov, M.S. \& Schulgina, N.I. 1988: Ammonitovye zony pogranitshnych otlozhenij jury i mela v borealnoj oblasti. (Ammonite zones of the Jurassic/Cretaceous Boundary Deposits in the Boreal Realm.) Izvestija Akademii Nauk SSSR, Serija geologitsheskaja 1988(10), 71-83 (in Russian).

Kelli [Kelly], S.R.A. 1990: Biostratigrafija verchnejurskich i nizhnemelovyich otlozhenij Evropy po Buchijam. (Biostratigraphy of the bivalve Buchia in the late Jurassic and Early Cretaceous sediments of Europe.) In: Menner, V.V. (ed.): Granica jury i mela. Akademija Nauk SSSR, Sibirskoe otdelenie, Instituta Geologii i Geofiziki Trudy 699, 129-151 (in Russian with English abstract).

Kießling, W. 1997: Radiolarien im nordbayerischen Oberjura. Geologische Blätter für Nordost-Bayern und angrenzende Gebiete 47, 25-52.

Klieber, D. 1981: Zum Problem der Abgrenzung von Amoeboceras alternans (von Buch 1831) und Amoeboceras ovale (Quenstedt 1849). Geologische Blätter für Nordost-Bayern und angrenzende Gebiete 31, 271-284.

Klingler, W., Malz, H. \& Martin, G.P.R. 1962: Malm NW-Deutschlands. In: Arbeitskreis deutscher Mikropaläontologen (eds): Leitfossilien der Mikropaläontologie, Ein Abriss 159-190. BerlinNikolassee: Gebrüder Borntraeger.

Koerner, U. 1963: Beiträge zur Stratigraphie und Ammonitenfauna der Weißjura $-\alpha / \beta$ - Grenze (Oberoxford) auf der westlichen Schwäbischen Alb. Jahreshefte des Geologischen Landesamtes Baden-Württemberg 6, 337-394.

Kozlova, G.E. 1994: Radiolarian marker horizons for the Mesozoic of Pechora Basin and the Barents Shelf. 7th Interrad Conference (Osaka 1994). Abstracts, 69 only.

Krymholts, G.Y., Mesezhnikov, M.S. \& Westermann, G.E.G. (eds) 1988: The Jurassic ammonite zones of the Soviet Union. Geological Society of America Special Papers 223, 116 pp.

Kutek, J. 1994: The Scythicus Zone (Middle Volgian) in Poland: its ammonites and biostratigraphic subdivision. Acta Geologica Polonica 44, 1-33.

Kutek, J. \& Wierzbowski, A. 1986: A new account on the Upper Jurassic stratigraphy and ammonites of the Czorsztyn succession, Pieniny Klippen Belt, Poland. Acta Geologica Polonica 36, 289-316.

Kutek, J. \& Zeiss, A. 1974: Tithonian-Volgian ammonites from Brzostówka near Tomaszów Mazowiecki, Central Poland. Acta 
Geologica Polonica 24, 505-542.

Kutek, J. \& Zeiss, A. 1988: Further data on the correlation of the Middle/Upper Tithonian with the Lower/Middle Volgian boundary. In: Rocha, R.B. \& Soares, A.F. (eds): 2nd International Symposium on Jurassic stratigraphy (Lisbon 1987) 1, 623-640. Lisbon: Universidade Nova de Lisboa.

Kutek, J. \& Zeiss, A. 1994: Biostratigraphy of the highest Kimmeridgian and Lower Volgian in Poland. In: Cariou, E. \& Hantzpergue, P. (eds): 3rd International Symposium on Jurassic stratigraphy (Poitiers 1991). Geobios Mémoire Spécial 17, 337-341.

Kutek, J. \& Zeiss, A. 1997: The highest Kimmeridgian and Lower Volgian in Central Poland; their ammonites and biostratigraphy. Acta Geologica Polonica 47, 107-198.

Le Hégarat, G. \& Remane, J. 1968: Tithonique supérieur et berriasien de l'Ardeche et de l'Herault; corrélation des ammonites et des calpionelles. Geobios 1, 7-69.

Leinfelder, R.R. \& Wilson, R.C.L. 1998: Third-order sequences in an Upper Jurassic rift-related second-order sequence, central Lusitanian Basin, Portugal. In: de Graciansky, P.-C. et al. (eds): Mesozoic and Cenozoic sequence stratigraphy of European basins. SEPM (Society for Sedimentary Geology) Special Publication 60, 507-526.

Lentin, J.K. \& Vozzhennikova, T.F. 1990: Fossil dinoflagellates from the Jurassic, Cretaceous and Paleogene deposits of the USSR - a re-study. American Association of Stratigraphic Palynologists Contributions Series 23, 221 pp.

Lopez Marques, B.F. 1983: O Oxfordiano - Kimeridgiano do Algarve oriental: estratigrafia, paleobiologia (Ammonoidea) et paleobiogeografia, $547 \mathrm{pp}$. Unpublished doctoral dissertation, Universidade Nova de Lisboa, Portugal.

Malinowska, L. 1988: Lower Kimmeridgian biostratigraphy in Poland. Biuletyn Pánstwowego Instytutu Geologicznego 359, 43-60.

Malinowska, L. 1991: Boreal fauna influences in Upper Oxfordian in North and Central Poland. Prace Pánstwowego Instytutu Geologicznego 135, 1-27.

Malinowska, L. 1997: Jura górna. Biostratygrafia. Makrofauna. In: Marek, S. \& Pajchlova, M. (eds): The epicontinental Permian and Mesozoic in Poland. Prace Pánstwowego Instytutu Geologicznego 153, 283-300.

Malinowska, L., Dembowska, J., Kutek, J., Brochwicz-Lewinski, W., Wierzbowski, A. \& Lefeld, J. 1988: Order Ammonitida Zittel, 1884. In: Malinowska, L. (ed.): Geology of Poland 3(2b), 313-353. Warsaw: Wydawnictwa Geologiczne.

Marcou, J. 1848: Recherches géologiques sur le Jura salinois. Mémoires de la Société géologique de France Ser. 2, 3(1), 101-113.

Marek, S. \& Pajchlova, M. (eds) 1997: The epicontinental Permian and Mesozoic in Poland. Prace Pánstwowego Instytutu Geologicznego 153, 452 pp.

Marek, S. \& Shulgina, N. 1996: Biostratigraphic correlation between Lower Cretaceous deposits in the central region of East-European Platform and the Polish Lowlands. Kwartalnik Geologiczny 40, 129-140.

Marek, S., Rajska, M. \& Sztejn, J. 1989: Stratigraphy of the Jurassic/Cretaceous Passage Beds in Central Poland (Kujawy
Area). Bulletin of the Polish Academy of Sciences, Earth Sciences 37, 131-141.

Matyja, B.A. \& Wierzbowski, A. 1988: The two Amoeboceras invasions in submediterranean Late Oxfordian of Central Poland. In: Rocha, R.B. \& Soares, A.F. (eds): 2nd International Symposium on Jurassic stratigraphy (Lisbon 1987) 1, 421-432. Lisbon: Universidade Nova de Lisboa.

Matyja, B.A. \& Wierzbowski, A. 1994: On correlation of submediterranean and boreal ammonite zonations of the middle and upper Oxfordian: new data from Central Poland. In: Cariou, E. \& Hantzpergue, P. (eds): 3rd International Symposium on Jurassic stratigraphy (Poitiers 1991). Geobios Mémoire Spécial 17, 351-358.

Matyja, B.A. \& Wierzbowski, A. 1995: Biogeographic differentiation of the Oxfordian and Early Kimmeridgian ammonite faunas of Europe, and its stratigraphic consequences. Acta Geologica Polonica 45, 1-8.

Matyja, B.A. \& Wierzbowski, A. 1997: The quest for a unified Oxfordian/Kimmeridgian boundary: implications of the ammonite succession at the turn of the Bimammatum and Planula Zones in the Wielun Upland, Central Poland. Acta Geologica Polonica 47, 77-105.

Matyja, B.A. \& Wierzbowski, A. 1998: The stratigraphical and palaeogeographical importance of the Oxfordian and Lower Kimmeridgian succession in the Kcynia IV borehole. Biuletyn Pánstwowego Instytutu Geologicznego 382, 35-70.

Maubeuge, P.L. (ed.) 1964: Colloque du Jurassique à Luxembourg 1962, 948 pp. Luxembourg: L'Institut Grand-Ducal.

Maubeuge, P.L. (ed.) 1970: Colloque du Jurassique à Luxembourg 1967, 40 pp. Luxembourg: Musée d'Histoire Naturelle.

Meléndez, G. 1989: El Oxfordianse en el sector central de la Cordillera Iberica (Provincias de Zaragoza y Teruel), 418 pp. Zaragoza-Teruel: Institución Fernando el Católico.

Meléndez, G. (ed.) 1990: Oxfordian Working Group meeting, Zaragoza - Iberian Chain 1988. Publicaciones del Seminario de Paleontologia de Zaragoza 2, 216 pp.

Meléndez, G. 1995: Proceeding of the voting process for the most idoneous section for Oxfordian GSSP. International Subcommission on Jurassic Stratigraphy Newsletter 23, 103-105.

Meléndez, G. \& Fontana, B. 1993: Biostratigraphic correlation of the Middle Oxfordian sediments in the Iberian Chain, eastern Spain. Acta Geologica Polonica 43, 193-211.

Meléndez, G., Atrops, F., Fortwengler, D., Marchand, D., Ogg, J., Poulsen, N.E., Page, K. \& Wright, J. 1998: On the proposal of the Thuoux-Savournon sections (Haute Provence, SE France) as the GSSP for the Callovian-Oxfordian boundary. In: Pálfy, J. (compiler): 5th International Symposium on the Jurassic System (Vancouver 1998). Abstracts and Program, 60-61. Vancouver: International Union of Geological Sciences.

Menner, V.V. (ed.) 1990: Granica jura i mela. International field meeting on Jurassic-Cretaceous boundary problems at the northern Caucasus 1987. Akademija Nauk SSSR, Sibirskoe otdelenie, Instituta Geologii i Geofiziki Trudy 699, 192 pp.

Mesezhnikov, M.S. 1984: Kimmeridzhskij i Volzhskij jarusy severa SSSR, 166 pp. (Kimmeridgian and Volgian stages of the northern USSR.) Leningrad: Nedra (in Russian).

Mesezhnikov, M.S. 1988: Oxfordian. Kimmeridgian. Tithonian 
(Volgian). In: Krymholts, G.Y., Mesezhnikov, M.S. \& Westermann, G.E.G. (eds): The Jurassic ammonite zones of the Soviet Union. Geological Society of America Special Papers 223, 39-62.

Mesezhnikov, M.S. (ed.) 1989: The Middle and Upper Oxfordian of the Russian Platform. Academy of Sciences of the USSR, Ministry of Geology, Interdepartmental Stratigraphic Committee of the USSR. Transactions 19, $181 \mathrm{pp}$.

Michelsen, O. \& Zeiss, A. (eds) 1984: International Symposium on Jurassic stratigraphy (Erlangen 1984) 1-3, 908 pp. Copenhagen: Geological Survey of Denmark.

Mitta, V.V. 1993: Ammonity i zonalnaja stratigrafija srednevolzhskich otlozhenij zentralnoj Rossii, 129 pp. (Ammonites and zonal stratigraphy of Middle Volgian deposits of Central Russia.) Kiev: Geoprognoz (in Russian with summaries in French, German and English).

Mönning, E. 1998: A stratigraphical framework for the Oxfordian deposits in NW-Germany. In: Pálfy, J. (compiler): 5th International Symposium on the Jurassic System (Vancouver 1998). Abstracts and Program, 63-64. Vancouver: International Union of Geological Sciences.

Mönning, E. \& Bertling, M. 1995: Mittlerer und Oberer Jura zwischen Weser und Leine mit besonderer Berücksichtigung des Oxfordiums (Stratigraphie, Fazies). Terra Nostra 95(5), 85-125.

Nikolov, T.G. \& Sapunov, I.G. (eds) 1977: International Symposium on the Jurassic/Cretaceous Boundary in Bulgary, Sofia-Elena 1977. Excursion guidebook, 127 pp. Sofia: Sofia University Press.

Norling, E. 1972: Jurassic stratigraphy and foraminifera of western Scania, southern Sweden. Sveriges Geologiska Undersökning Serie Ca 47, 120 pp.

Nowak, W.A. 1988: Suborder Tintinnina Claparède et Lehmann, 1858. In: Malinowska, L. (ed.): Geology of Poland 3(2b), 239-244. Warsaw: Wydawnictwa Geologiczna.

Odin, G.S., Galbrun, B. \& Renard, M. 1994: Physico-chemical tools in Jurassic stratigraphy. In: Cariou, E. \& Hantzpergue, P. (eds): 3rd International Symposium on Jurassic stratigraphy (Poitiers 1991). Geobios Mémoire Spécial 17, 507-518.

Ogg, J.G. 1983: Magnetostratigraphy of Upper Jurassic and lowest Cretaceous sediments, Deep Sea Drilling Project site 534, western North Atlantic. Initial Reports of the Deep Sea Drilling Project 76, 685-697.

Ogg, J.G. 1995: Mesozoic magnetic polarity time scale. International Subcommission on Jurassic Stratigraphy Newsletter 23, 73-85.

Ogg, J.G. \& Coe, A.L. 1998: Oxfordian magnetic polarity scale. In: Pálfy, J. (compiler): 5th International Symposium on the Jurassic System (Vancouver 1998). Abstracts and Program, 67 only. Vancouver: International Union of Geological Sciences.

Ogg, J.G. \& Gutowski, J. 1996: Oxfordian and Lower Kimmeridgian magnetic polarity time scale. GeoResearch Forum 1-2, 406-413.

Ogg, J.G. \& Lowrie, W. 1986: Magnetostratigraphy of the Jurassic/Cretaceous boundary. Geology 14, 547-550.

Ogg, J.G. \& Steiner, M.B. 1988a: Magnetostratigraphy of the Callovian and Oxfordian. In: Rocha, R.B. \& Soares, A.F. (eds): 2nd International Symposium on Jurassic stratigraphy (Lisbon 1987) 2, 1113-1124. Lisbon: Universidade Nova de Lisboa.

Ogg, J.G. \& Steiner, M.B. 1988b: Late Jurassic and Early Cretaceous magnetic polarity time scale. In: Rocha, R.B. \& Soares, A.F. (eds): 2nd International Symposium on Jurassic stratigraphy (Lisbon 1987) 2, 1125-1138. Lisbon: Universidade Nova de Lisboa.

Ogg, J.G., Steiner, M.B., Olóriz, F. \& Tavera, J.M. 1984: Jurassic magnetostratigraphy, 1 . Kimmeridgian-Tithonian of Sierra Gorda and Carcabuey, southern Spain. Earth and Planetary Science Letters 71, 147-162.

Ogg, J.G., Steiner, M.B., Wieczorek, J. \& Hoffmann, M. 1991 Jurassic magnetostratigraphy, 4. Early Callovian through Middle Oxfordian of the Krakow uplands (Poland). Earth and Planetary Science Letters 104, 488-504.

Ogg, J.G., Hassenyager, R.W. \& Wimbledon, W.A. 1994: Jurassic-Cretaceous boundary: Portlandian-Purbeck magnetostratigraphy and possible correlation to the Tethyan faunal realm. In: Cariou, E. \& Hantzpergue, P. (eds): 3rd International Symposium on Jurassic stratigraphy (Poitiers 1991). Geobios Mémoire Spécial 17, 519-527.

Olóriz, F. 1978: Kimmeridgense-Tithonico inferior en el Sector Central de las Cordilleras Béticas (Zona Subbetica). Paleontología. Bioestratigrafia I-II, 758 pp. Tesis doctorales de la Universidad de Granada 184. Granada: Imprenta de la Universidad de Granada, España.

Olóriz, F. \& Rodríguez-Tovar, F.J. 1996: The ammonite Sutneria from the Upper Jurassic of southern Spain. Palaeontology 39, 851-867.

Olóriz, F., Marques, B. \& Rodríguez-Tovar, F.J. 1991: Eustatism and faunal associations. Examples from the South Iberian Margin during the Late Jurassic (Oxfordian-Kimmeridgian). Eclogae Geologicae Helvetiae 84, 83-106.

Olóriz, F., Caracuel, J.E., Marques, B. \& Rodríguez-Tovar, F.J. 1995: Asociaciones de Tintinnoides en facies Ammonitico Rosso de la Sierra Norte (Mallorca). Revista Española de Paleontología, N. ${ }^{\circ}$ Homenaje al Dr. Guillermo Colom, 77-93.

Oppel, A. 1858: Die Juraformation Englands, Frankreichs und des südwestlichen Deutschlands. Jahreshefte des Vereins für Vaterländische Naturkunde 14, 121-291.

Oppel, A. 1865: Die tithonische Etage. Zeitschrift der Deutschen Geologischen Gesellschaft 17, 535-558.

Oppel, A. \& Waagen, W. 1866: Über die Zone des Ammonites transversarius. Geognostisch-paläontologische Beiträge $\mathbf{1}$, 205-318.

Page, K.N. 1995: Biohorizons and zonules: intra-subzonal units in Jurassic ammonite stratigraphy. Palaeontology 38, 801-814.

Pálfy, J. (compiler) 1998: 5th International Symposium on the Jurassic System (Vancouver 1998). Abstracts and Program, 101 pp. Vancouver: International Union of Geological Sciences.

Pálfy, J., Smith, P.L. \& Mortensen, J.K. 1998: A U-Pb and Ar-Ar time scale for the Jurassic. In: Pálfy, J. (compiler): 5th International Symposium on the Jurassic System (Vancouver 1998). Abstracts and Program, 72 only. Vancouver: International Union of Geological Sciences.

Pavia, G., Benetti, A. \& Minetti, C. 1987: Il Rosso Ammonitico dei Monte Lessini Veronesi (Italia NE). Faune ad Ammoniti e discontinuità stratigrafiche nel Kimmeridgiano inferiore. Bolletino della Società Paleontologica Italiana 26, 63-92.

Poulsen, N.E. 1996: Dinoflagellate cysts from marine Jurassic deposits of Denmark and Poland. American Association of 
Stratigraphic Palynologists Contributions Series 31, 227 pp.

Poulsen, N.E. \& Riding, J.B. 2003: The Jurassic dinoflagellate cyst zonation of Subboreal Northwest Europe. In: Ineson, J.R. \& Surlyk, F. (eds): The Jurassic of Denmark and Greenland. Geological Survey of Denmark and Greenland Bulletin 1, 115-144 (this volume).

Proust, J.N., Deconinck, J.-F., Geyssant, J.R., Herbin, J.-P. \& Vidier, J.-P. 1993: Nouvelles données sédimentologiques dans le Kimmeridgien et le Tithonien du Boulonnais (Nord de la France). Comptes Rendus de l'Académie des Sciences (Paris) Série 2 316, 363-369.

Prozorovskaja, E.L. 1993: Brachiopod subdivisions in the Jurassic of the southern ex-USSR. Palaeogeography, Palaeoclimatology, Palaeoecology 100, 183-188.

Pugaczewska, H. 1988: Order Belemnitida Naef, 1912. In: Malinowska, L. (ed.): Geology of Poland 3(2b), 354-356. Warsaw: Wydawnictwa Geologiczne.

Rawson, P.F., Curry, D., Dilley, F.C., Hancock, J.M., Kennedy, W.J., Neale, J.W., Wood, C.J. \& Worssam, B.C. 1978: A correlation of Cretaceous rocks in the British Isles. Geological Society Special Report (London) 9, 70 pp.

Reháková, D. 1995: Nové poznatky o distribúcii kalpionellíid vo vrchnojurských a spodnokriedových súvrstviach Západných Karpát. (New data on calpionellid distribution in the Upper Jurrassic/Lower Cretaceous formations (Western Carpathians).) Mineralia Slovaka 27, 308-318.

Reháková, D. 2000: Calcareous dinoflagellate and calpionellid bioevents versus sea-level fluctuations recorded in the WestCarpathian (Late Jurassic/Early Cretaceous) pelagic environments. Geologica Carpathica 51(4), 229-243.

Reháková, D. \& Michalík, J. 1997: Evolution and distribution of calpionellids - the most characteristic constituents of Lower Cretaceous Tethyan microplankton. Cretaceous Research 18, 493-504.

Řehánek, J. 1990: Kalpionelidy z Jury a Křídy Jihovýchodních svahú Českého masívu. (Calpionellids from the Jurassic and Cretaceous limestones on the southeast slopes of the Bohemian massif.) Knihovička Zemního plynu a naftu 9b, 185-208.

Remane, J. 1986: Calpionellids and the Jurassic-Cretaceous boundary. Acta Geologica Hungarica 29, 15-26.

Remane, J. 1991: From biostratigraphy to biochronology: time correlation by fossils. XIe Congrès International de Stratigraphie et de Géologie du Carbonifère, Beijing 1987. Compte Rendu 1, 187-200.

Remane, J. 1996: The revised guidelines of ICS and their bearing on Jurassic chronostratigraphy. GeoResearch Forum 1-2, $19-22$.

Remane, J. 1997: Les zones de Calpionelles du passage JurassiqueCrétacé. In: Cariou, E. \& Hantzpergue, P. (eds): Biostratigraphie du Jurassique ouest-européen et méditerranéen: zonations parallèles et distribution des invertébrés et microfossiles. Bulletin du Centre Recherches Elf Exploration Production Mémoire 17, 243-247.

Remane, J. 1998: Les calpionelles: possibilités biostratigraphiques et limitations paléobiogéographiques. Bulletin de la Société géologique de France 169, 829-839.

Remane, J., Bakalova-Ivanova, D., Borza, K., Knauer, J., Nagy, I.,
Pop, G. \& Tardi-Filácz, E. 1986: Agreement on the subdivision of the Standard Calpionellid zones defined at the 2nd Planktonic Conference, Roma 1970. Acta Geologica Hungarica 29, 5-13.

Remane, J., Bassett, M.G., Cowie, J.W., Gohrbrandt, K.L., Lane, R.H., Michelsen, O. \& Naiwen W. 1996: Revised guidelines for the establishment of global chronostratigraphic standards by the International Commission on Stratigraphy (ICS). Episodes 19, 77-81.

Riccardi, A.C. (ed.) 1996: 4th International Symposium on Jurassic stratigraphy (Mendoza 1994). Advances in Jurassic research. GeoResearch Forum 1-2, 496 pp.

Riding, J.B. \& Sarjeant, W.A.S. 1984: The role of dinoflagellate cysts in the biostratigraphical subdivision of the Jurassic System. In: Michelsen, O. \& Zeiss, A. (eds): International Symposium on Jurassic stratigraphy (Erlangen 1984) 1, 87-103. Copenhagen: Geological Survey of Denmark.

Riding, J.B. \& Thomas, J.E. 1992: Dinoflagellate cysts of the Jurassic System. In: Powell, A.J. (ed.): A stratigraphic index of dinoflagellate cysts, 7-97. British Micropalaeontological Society Publication Series. London: Chapman \& Hall.

Riegraf, W. 1980: Revision der Belemniten des Schwäbischen Jura, Teil 7. Palaeontographica A 169, 128-206.

Riegraf, W. 1981: Revision der Belemniten des Schwäbischen Jura, Teil 8 (Schluss). Palaeontographica A 173, 64-139.

Riegraf, W. 1987: Planktonische Foraminiferen und Radiolarien im Callovium und Oxfordium (Jura) Süddeutschlands. Neues Jahrbuch für Geologie und Paläontologie Abhandlungen 176, 91-103.

Riley, L.A. 1980: The stratigraphic distribution of dinoflagellate cysts at the boreal Jurassic/Cretaceous boundary. 4th International Palynology Conference (Lucknow 1976-77). Proceedings 2, 313-329.

Riley, L.A. \& Fenton, J.P.G. 1982: A dinocyst zonation for the Callovian to Middle Oxfordian succession (Jurassic) of Northwest Europe. Palynology 6, 193-202.

Riveline, J., Berger, J.-P., Feist, M., Martin-Closas, C., Schudack, M. \& Soulié-Märsche, I. 1996: European Mesozoic-Cenozoic charophyte biozonation. Bulletin de la Société géologique de France 167, 453-468.

Rocha, R.B. \& Soares, A.F. (eds) 1988: 2nd International Symposium on Jurassic stratigraphy (Lisbon 1987) 1-2, 1178 pp. Lisbon: Universidade Nova de Lisboa.

Roniewicz, E. \& Morycowa, E. 1988: Order Scleractinia Bourne, 1900. In: Malinowska, L. (ed.): Geology of Poland 3(2b), 255-266. Warsaw: Wydawnictwa Geologiczne.

Rosendahl, S. 1988: Upper Jurassic hermatypic corals of Algarve - paleoecological and stratigraphical importance. In: Rocha, B.R. \& Soares, A.F. (eds): 2nd International Symposium on Jurassic stratigraphy (Lisbon 1987) 2, 877-888. Lisbon: Universidade Nova de Lisboa.

Rostovtsev, K.O. \& Prozorovskiy, V.A. 1997: Information on resolutions of standing commissions of the Interdepartmental Stratigraphic Committee (ISC) on the Jurassic and Cretaceous Systems. International Subcommission on Jurassic Stratigraphy Newsletter 24, 48-49.

Rotkyte, L. 1976: Volzhskie ammonity Pribaltiki. (Volgian ammo- 
nites of the Baltic region.) Doklady Akademii Nauk SSSR 230, 1193-1196 (in Russian).

Rotkyte, L. 1987: Ammonity i zonalnaja stratigrafija Verchnejurskich otlozhenij Pribaltiki, 120 pp. (Ammonites and zonal stratigraphy of Upper Jurassic deposits of the Baltic region.) Vilnjus: Mokslas (in Russian).

Ruget, C. \& Nicollin, J.-P. 1997: Les petits Foraminfères benthiques dégagés. In: Cariou, E. \& Hantzpergue, P. (eds): Biostratigraphie du Jurassique ouest-européen et méditerranéen: zonations parallèles et distribution des invertébrés et microfossiles. Bulletin du Centre Recherches Elf Exploration Production Mémoire 17, 281-291.

Sahagian, D., Pinous, O., Olferiev, A. \& Zakharov, V. 1996: Eustatic curve for the Middle Jurassic - Cretaceous based on Russian platform and Siberian stratigraphy: zonal resolution. AAPG Bulletin 80, 1433-1458.

Saks, V.N. (ed.) 1979: Verchnjaja Jura i granica ee s melovoj sistemoj, 215 pp. (International Colloquium on the 'Upper Jurassic and its boundary with the Cretaceous System'.) Novosibirsk: Izdatelstro <Nauka>, Sibirskoe otdelenie (in Russian).

Saks, V.N. \& Nalnjaeva, T.I. 1964: Verchnejurskie i nizhnemelovye belemnity severa SSSR. Rody Cylindroteuthis i Lagonibelus, 167 pp. (Upper Jurassic and Lower Cretaceous belemnites of the northern USSR. Genera Cylindroteuthis and Lagonibelus.) Moscow-Leningrad: Nauka Akademija (in Russian).

Saks, V.N. \& Nalnjaeva, T.I. 1966: Verchnejurskie i nizhnemelovye belemnity severa SSSR. Rody Pachyteuthis i Acroteuthis, 259 pp. (Upper Jurassic and Lower Cretaceous belemnites of the northern USSR. Genera Pachyteuthis and Acroteuthis.) Moscow-Leningrad: Nauka Akademija (in Russian).

Salfeld, H. 1915: Monographie der Gattung Cardioceras Neumayr et Uhlig. Teil 1. Die Cardioceraten des oberen Oxford und Kimmeridge. Zeitschrift der Deutschen Geologischen Gesellschaft 67, 149-204.

Salvador, A. (ed.) 1994: International stratigraphic guide. A guide to stratigraphic classification, terminology and procedure, 2nd edition, 214 pp. Boulder, Colorado: International Union of Geological Sciences and Geological Society of America.

Sapunov, I.G. 1976: Ammonite stratigraphy of the Upper Jurassic in Bulgaria. 2. Oxfordian: substages, zones and subzones. Geologica Balcanica 6(4), 19-36.

Sapunov, I.G. 1977a: Ammonite stratigraphy of the Upper Jurassic in Bulgaria. 3. Kimmeridgian: substages, zones and subzones. Geologica Balcanica 7(1), 63-80.

Sapunov, I.G. 1977b: Ammonite stratigraphy of the Upper Jurassic in Bulgaria. 4. Tithonian: substages, zones and subzones. Geologica Balcanica 7(2), 43-64.

Sapunov, I.G. 1979: Jurassique supérieur. Ammonoidea. In: Tzankov, V. (ed.): Les fossiles de Bulgarie 3(3), 263 pp. Sofia: Academie Bulgare des Sciences.

Sarjeant, W.A.S. 1979: Middle and Upper Jurassic dinoflagellate cysts: the world excluding North America. American Association of Stratigraphic Palynologists Contributions Series 58, 133-156.

Sarti, C. 1984: Fauna e biostratigrafia del Rosso Ammonitico del Trentino centrale (Kimmeridgiano-Tithoniano). Bolletino della Società Paleontologica Italiana 23, 473-514.

Sarti, C. 1988: Biostratigraphic subdivision for the Upper Jurassic of the Venetian Alps (northern Italy) on the basis of ammonites. In: Rocha, B.R. \& Soares, A.F. (eds): 2nd International Symposium on Jurassic stratigraphy (Lisbon 1987) 1, 459-476. Lisbon: Universidade Nova de Lisboa.

Sarti, C. 1993: Il Kimmeridgiano delle Prealpi Veneto-Trentine: Fauna e biostratigrafia. Memorie del Museo Civico di Storia Naturale di Verona Serie 2a, Sezione Scienze della Terra 5, 144 pp.

Sasonova, J.G. \& Sasonov, N.T. 1979: The Jurassic-Cretaceous boundary in the East European Platform. In: Wiedman, J. (ed.): Aspekte der Kreide Europas. International Union of Geological Sciences Series A 6, 487-496.

Schairer, G. 1970: Quantitative Untersuchungen an Sutneria platynota (Reinecke) (Perisphinctidae, Ammonoidea) der fränkischen Alb (Bayern). Mitteilungen der Bayerischen Staatssammlung für Paläontologie und Historische Geologie 10, $153-174$.

Scherzinger, A. \& Schweigert, G. 1999: Die Ammoniten-Faunenhorizonte der Neuburg-Formation (Oberjura, Südliche Frankenalb) und ihre Beziehungen zum Volgium. Mitteilungen der Bayerischen Staatssammlung für Paläontologie und Historische Geologie 39, 3-12.

Schlegelmilch, R. 1994: Die Ammoniten des süddeutschen Malms. Ein Bestimmungsbuch für Geowissenschaftler und Fossiliensammler, 297 pp. Stuttgart: Gustav Fischer Verlag.

Schudack, M.E. 1991: Eine Charophyten-Biozonierung für den Zeitraum Oberjura bis Berriasium in Westeuropa und ihr Vergleich mit Sequenzstratigraphie und eustatischer Meeresspiegelkurve. Berliner Geowissenschaftliche Abhandlungen A 134, 311-332.

Schudack, M.E. 1993: Die Charophyten in Oberjura und Unterkreide Westeuropas. Mit einer phylogenetischen Analyse der Gesamtgruppe. Berliner Geowissenschaftliche Abhandlungen E 8, 209 pp.

Schudack, M.E. 1996a: Die Charophyten des Niedersächsischen Beckens (Oberjura-Berriasium): Lokalzonierung, überregionale Korrelation und Palökologie. Neues Jahrbuch für Geologie und Paläontologie Abhandlungen 200, 27-52.

Schudack, M.E. 1996b: Charophyten des Kimmeridgium, Tithonium und Berriasium aus Bohrungen in Mecklenburg und Brandenburg (Nordostdeutschland). Hallesches Jahrbuch für Geowissenschaften B 18, 153-170.

Schudack, U. 1994: Revision, Dokumentation und Stratigraphie der Ostracoden des nordwestdeutschen Oberjura und UnterBerriasium. Berliner Geowissenschaftliche Abhandlungen E 11, 193 pp.

Schweigert, G. 1993a: Die Ammonitengattungen Gravesia Salfeld und Tolvericeras Hantzpergue und ihre Bedeutung für den Grenzbereich Oberkimmeridgium/Untertithonium im Schwäbischen Jura. Geologische Blätter für Nordost-Bayern und angrenzende Gebiete 43, 167-186.

Schweigert, G. 1993b: Subboreale Faunenelemente (Ammonoidea) im oberen Weißjura (Oberkimmeridgium) der Schwäbischen Alb. Profil 5, 141-155.

Schweigert, G. 1994: Über einige bemerkenswerte Ammoniten im Oberkimmeridgium der Schwäbischen Alb (Südwestdeutschland). Stuttgarter Beiträge zur Naturkunde Serie B 203, $1-15$. 
Schweigert, G. 1995a: Amoebopeltoceras n.g., eine neue Ammonitengattung aus dem Oberjura (Ober-Oxfordium bis UnterKimmeridgium) von Südwestdeutschland und Spanien. Stuttgarter Beiträge zur Naturkunde Serie B 227, 1-12.

Schweigert, G. 1995b: Zum Auftreten der Ammonitenarten Amoeboceras baubini (Oppel) und Amoeboceras schulginae Mesezhnikov im Oberjura der Schwäbischen Alb. Jahrbuch der Gesellschaft für Naturkunde in Württemberg 151, 171-184.

Schweigert, G. 1996a: Historische Ammonitenfunde an der Porta Westfalica und deren Bedeutung für die Stratigraphie des nordwestdeutschen Oberjura. Osnabrücker Naturwissenschaftliche Mitteilungen 22, 23-34.

Schweigert, G. 1996b: Die Hangende Bankkalk-Formation im Schwäbischen Oberjura. Jahresberichte und Mitteilungen des Oberrheinischen Geologischen Vereins 78, 281-308.

Schweigert, G. 1998: Die Ammonitenfauna des Nusplinger Plattenkalkes (Ober-Kimmeridgium, Beckeri-Zone, UlmenseSubzone, Baden-Württemberg). Stuttgarter Beiträge zur Naturkunde Serie B 267, 61 pp.

Schweigert, G. \& Callomon, J.H. 1997: Der baubini-Faunenhorizont und seine Bedeutung für die Korrelation zwischen tethyalem and subborealem Oberjura. Stuttgarter Beiträge zur Naturkunde Serie B 247, 69 pp.

Schweigert, G. \& Zeiss, A. 1994: Ammonite biostratigraphy of the Upper Kimmeridgian to Tithonian of southern Germany. In: Leinfelder, R. (ed.): The origin of Jurassic reefs: current research developments and results. Facies 31, 27-28.

Schweigert, G. \& Zeiss, A. 1998: Berckhemeria n.g. (Passendorferiinae), eine neue Ammonitengattung aus dem UnterTithon (Hybonotum-Zone) von Süddeutschland. Neues Jahrbuch für Geologie und Paläontologie Monatshefte $\mathbf{1 9 9 8}$ 559-576.

Schweigert, G. \& Zeiss, A. 1999: Lithacoceras ulmense (Oppel) (Ammonitina) - eine wichtige Leitart des Ober-Kimmeridgiums. Neues Jahrbuch für Geologie und Paläontologie Abhandlungen 211, 49-73.

Schweigert, G., Krischna, J., Pandey, B. \& Pathak, D.B. 1996: A new approach to the correlation of the Upper Kimmeridgian Beckeri Zone across the Tethyan Sea. Neues Jahrbuch für Geologie und Paläontologie Abhandlungen 202, 345-373.

Sequeiros, L. 1974: Paleobiogeografia del Calloviense y Oxfordense en el sector central de la Zona Subbetica 1, 274 pp., 2, 361 pp. Tesis doctorales de la Universidad de Granada 65. Granada: Imprenta de la Universidad de Granada, España.

Sey, I.I. \& Kalacheva, E.D. 1993a: Biostratigrafitsheskie kriterii granizy jurskoj i melovoj sistem dlja territorii Rossii. (Biostratigraphic criteria of the Jurassic-Cretaceous boundary of Russia.) Slyzhebno-informazionnaja zapiska 1993, 62 pp. Sankt-Petersburg: Roskomnedra i Vsegei (in Russian with English summary).

Sey, I.I. \& Kalacheva, E.D. 1993b: Buchiidy i zonalnaja stratigrafija verchnejurskich otlozhenij severnoj tshasti Dalnego Vostoka Rossii. (Buchiids and zonal stratigraphy of the Upper Jurassic deposits of the northern Far East of Russia.) Akademija Nauk SSSR, Sibirskoe otdelenie, Geologia i Geofizika 1993(8), 46-60. Novosibirsk: Nauka, Sibirskoe otdelenie (in Russian).

Sha, J. \& Fürsich, F. 1994: Bivalve faunas of eastern Heilongjigang, northeastern China. 2nd Beringeria 12, $92 \mathrm{pp}$

Shipp, D. \& Murray, J.W. 1981: Jurassic; Part Three, The Callovian to Portlandian. In: Jenkins, D.G. \& Murray, J.W. (eds): Stratigraphical atlas of fossil foraminifera, 125-144. British Micropalaeontological Society Publication Series. Chichester: Ellis Horwood.

Steiner, M.B., Ogg, J.G., Meléndez, G. \& Sequeiros, L. 1985: Jurassic magnetostratigraphy, 2. Middle-Late Oxfordian of Aguilon, Iberian Cordillera, northern Spain. Earth and Planetary Science Letters 76, 151-166.

Styk, O. 1997: Otwornice - Foraminifera. In: Marek, S. \& Pajchlova, M. (eds): The epicontinental Permian and Mesozoic in Poland. Prace Pánstwowego Instytutu Geologicznego 153, 300-307.

Surlyk, F. 1991: Sequence stratigraphy of the Jurassic - lowermost Cretaceous of East Greenland. AAPG Bulletin 75, 1468-1488.

Surlyk, F. 2003: The Jurassic of East Greenland: a sedimentary record of thermal subsidence, onset and culmination of rifting. In: Ineson, J.R. \& Surlyk, F. (eds): The Jurassic of Denmark and Greenland. Geological Survey of Denmark and Greenland Bulletin 1, 659-722 (this volume).

Surlyk, F. \& Zakharov, V.A. 1982: Buchiid bivalves from the Upper Jurassic and Lower Cretaceous of East Greenland. Palaeontology 25, 727-753.

Sykes, R.M. \& Callomon, J.H. 1979: The Amoeboceras zonation of the Boreal Upper Oxfordian. Palaeontology 22, 839-903.

Sztejn, J. 1997: Mikrofauna - Maloraczki. (Ostracoda.) In: Marek, S. \& Pachlowej, M.: The epicontinental Permian and Mesozoic in Poland. Prace Pánstwowego Instytutu Geologicznego 153, 308 pp.

Tarkowski, R. 1990: Les Taramelliceras (Ammonitina) de l'oxfordien inférieur du Jurassique Cracovien: valeur stratigraphique. Publicaciones del Seminario de Paleontologia de Zaragoza 2, 205-221.

Tavera, J.M. 1985: Los ammonites del Tithonico superior Berriasense de la Zona Subbética (Cordilleras Béticas), 381 pp. Unpublished Ph.D. thesis, Universidad de Granada, España.

Tavera, J.M., Aguado, R., Company, M. \& Olóriz, F. 1994: Integrated biostratigraphy of the Durangites and Jacobi zones $(\mathrm{J} / \mathrm{K}$ boundary) at the Puerto Escano section in southern Spain (Province of Cordoba). In: Cariou, E. \& Hantzpergue, P. (eds): 3rd International Symposium on Jurassic stratigraphy (Poitiers 1991). Geobios Mémoire Spécial 17, 469-476.

Taylor, P.D. (ed.) 1996: W.J. Arkell Symposium of Jurassic geology, London 1993. Field geology of the British Jurassic, 286 pp. London: Geological Society.

Thierry, J., Clavel, B., Hantzpergue, P., Neraudeau, D., Rigollet, L. \& Vadet, A. 1997: Distribution chronologique et géographique des Echinides jurassiques en France: Essai d'utilisation biostratigraphique. In: Cariou, E. \& Hantzpergue, P. (eds): Biostratigraphie du Jurassique ouest-européen et méditerranéen: zonations parallèles et distribution des invertébrés et microfossiles. Bulletin du Centre Recherches Elf Exploration Production Mémoire 17, 253-271.

Turner, C.E. \& Peterson, F. 1998: Biostratigraphy of dinosaurs in the Morrison Formation (Upper Jurassic) of Western Interior, USA. In: Pálfy, J. (compiler): 5th International Symposium on the Jurassic System (Vancouver 1998). Abstracts and Program, 
90-91. Vancouver: International Union of Geological Sciences.

Végh-Neubrandt, E. (ed.) 1971: Colloque du Jurassique méditerranéen, Budapest 1969. Annals of the Hungarian Geological Institute 54, $632 \mathrm{pp}$.

Vidier, J.P., Marchand, D., Bonnot, A. \& Fortwengler, D. 1993: The Callovian and Oxfordian of the Boulonnais area in northern France: new biostratigraphic data. Acta Geologica Polonica 43, 169-182.

Vigh, G. 1984: Die biostratigraphische Auswertung einiger Ammoniten-Faunen aus dem Tithon des Bakonygebirges sowie aus dem Tithon-Berrias des Gerescegebirges. Jahrbuch der Ungarischen Geologischen Anstalt 67, 5-210.

Vishnevskaya, V.S. 1993: Jurassic and Cretaceous radiolarian biostratigraphy in Russia. Micropaleontology Special Publication 6, 175-200.

Vishnevskaya, V.S. 1997: New Mesozoic Boreal radiolarian finding from Russia. Eighth Interrad Conference (Paris-Bierville 1997). Abstracts, 130 only.

Vishnevskaya, V.S. 1998: The Domanikoid facies of the Russian Platform and basin paleogeography. In: Crasquin-Soleau, S. \& Barrier, E. (eds): Peri-Tethys Memoir 3; Stratigraphy and evolution of Peri-Tethyan platforms. Mémoires du Muséum National d'Histoire Naturelle 177, 45-69.

Vishnevskaya, V.S. \& De Wever, P. 1997: Correlation of the Jurassic Peri-Tethyan radiolarian schemes. Eighth Interrad Conference (Paris-Bierville 1997). Abstracts, 133 only.

von Buch, L. 1839: Über den Jura in Deutschland. Abhandlungen der Königlichen Akademie der Wissenschaften 1837, 49-135.

Wick, W. \& Wolburg, J. 1962: Wealden in NW Deutschland. In: Arbeitskreis deutscher Mikropaläontologen (ed.): Leitfaden der Mikropaläontologie, 191-224. Berlin-Nikolaisee: Gebrüder Borntraeger.

Wierzbowski, A. 1978: Ammonites and stratigraphy of the Upper Oxfordian of the Wielún Upland, Central Poland. Acta Geologica Polonica 28, 299-333.

Wierzbowski, A. 1989: Ammonites and stratigraphy of the Kimmeridgian at Wimanfjellet, Sassenfjorden, Spitsbergen. Acta Palaeontologica Polonica 34, 355-378.

Wierzbowski, A. 1991: Biostratigraphical correlations around the Oxfordian/Kimmeridgian boundary. Acta Geologica Polonica 41, 149-155.

Wierzbowski, A. 1999: Comments on the selection of the Oxfordian/Kimmeridgian boundary stratotype. International Subcommission on Jurassic Stratigraphy Newsletter 27, 35-36.

Wierzbowski, A. 2001: Report of the Oxfordian/Kimmeridgian Boundary Working Group. International Subcommission on Jurassic Stratigraphy Newsletter 28, 9-10.

Wierzbowski, A. \& Århus, N. 1990: Ammonite and dinoflagellate cyst succession of an Upper Oxfordian - Kimmeridgian black shale core from the Nordkapp Basin, southern Barents Sea. Newsletters on Stratigraphy 22, 7-19.

Wierzbowski, A. \& Smelror, M. 1993: Ammonite succession in the Kimmeridgian of southwestern Barents Sea, and the Amoeboceras zonation of the Boreal Kimmeridgian. Acta Geologica Polonica 43, 229-249.

Wimbledon, W.A. 1980: Portlandian correlation chart. In: Cope, J.C.W. et al.: A correlation of Jurassic rocks in the British Isles.
Part Two: Middle and Upper Jurassic. Geological Society Special Report (London) 15, 85-93.

Wimbledon, W.A. \& Cope, J.C.W. 1978: The ammonite faunas of the English Portland Beds and the zones of the Portlandian Stage. Journal of the Geological Society (London) 135, 183-190.

Wright, J.K. [with a contribution by Callomon, J.H.] 1980: Oxfordian correlation chart. In: Cope, J.C.W. et al.: A correlation of Jurassic rocks in the British Isles. Part Two: Middle and Upper Jurassic. Geological Society Special Report (London) 15, 61-76.

Wright, J.K. 1989: The early Kimmeridgian ammonite succession at Staffin, Isle of Skye. Scottish Journal of Geology 25, 263-272.

Wright, J.K. 1996a: Perisphinctid ammonites of the Upper Calcareous Grit (Upper Oxfordian) of North Yorkshire. Palaeontology 39, 433-469.

Wright, J.K. 1996b: The Amoeboceras faunas of the Upper Calcareous Grit Formation (Jurassic, Upper Oxfordian) of North Yorkshire. Proceedings of the Yorkshire Geological Society 51, 33-43.

Zakharov, V.A. 1981: Buchiidy i biostratigrafija borealnoj verchnej jury i neokoma. (Buchiids and biostratigraphy of the Boreal Upper Jurassic and Neocomian.) Akademija Nauk SSSR, Sibirskoe otdelenie, Instituta Geologii i Geofiziki Trudy 458 , 271 pp. (in Russian).

Zakharov, V.A. 1987: The bivalve Buchia and the JurassicCretaceous boundary on the Boreal Province. Cretaceous Research 8, 141-153.

Zakharov, V.A. 1990: Opredelenie granizy jurskoj i melovoj sistem po Buchiidam. (Definition of Jurassic/Cretaceous boundary on Buchias.) Akademija Nauk SSSR, Sibirskoe otdelenie, Instituta Geologii i Geofiziki Trudy 699, 115-128 (in Russian with English abstract).

Zeiss, A. 1964: Zur Verbreitung der Gattung Gravesia im Malm

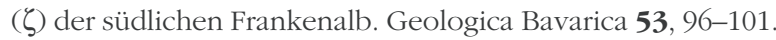

Zeiss, A. 1965: Gliederung und Grenzen des Oberen Jura in Europa. 7th Congress of the Carpatho-Balkan Geological Association, Sofia 1965. Reports, Part 2, Stratigraphy, lithology and palaeontology, 1, 107-113. Sofia: Bulgarian Academy of Sciences.

Zeiss, A. 1966: Biostratigraphische Auswertung von Ammonitenaufsammlungen im Profil des Malm $\alpha$ und $\beta$ am Feuerstein bei Ebermannstadt/Ofr. Erlanger Geologische Abhandlungen 62, 104-111.

Zeiss, A. 1968: Untersuchungen zur Paläontologie der Cephalopoden des Unter-Tithon der südlichen Frankenalb. Abhandlungen der Bayerischen Akademie der Wissenschaften, mathematisch-naturwissenschaftliche Klasse, Neue Folge $\mathbf{1 3 2}$ $190 \mathrm{pp}$.

Zeiss, A. 1974: Berechtigung und Gliederung der Tithon-Stufe und ihre Stellung im Oberen Jura. Mémoires du Bureau de Recherches Géologiques et Minières 75, 283-291.

Zeiss, A. 1975: On the type region of the lower Tithonian substage. Mémoires du Bureau de Recherches Géologiques et Minières 86, 370-377.

Zeiss, A. 1977: Jurassic stratigraphy of Franconia. Stuttgarter Beiträge zur Naturkunde Serie B 31, 32 pp.

Zeiss, A.G. 1979: Problema korreljazii v verchnej jure i nekotorye soobrazhenija o granize jury i mela. (Correlation problems 
in the Upper Jurassic and some remarks on the Jurassic/ Cretaceous boundary.) In: Saks, V.I. (ed.): Verchnaja Jura i graniza ees melovoj sistemoj, 14-29. Novosibirsk: Izdatelsto $<$ Nauka>, Sibirskoe otdelenie (in Russian).

Zeiss, A. 1983: Zur Frage der Äquivalenz der Stufen Tithon/ Berrias/Wolga/Portland in Eurasien und Amerika. Zitteliana 10, 427-438.

Zeiss, A. 1986: Comments on a tentative correlation chart for the most important marine provinces at the Jurassic/Cretaceous boundary. Acta Geologica Hungarica 29, 27-30.

Zeiss, A. 1991a: Report on the voting about the future usage of the Kimmeridgian and Tithonian stage names. International Subcommission on Jurassic Stratigraphy Newsletter 20, 16 only.

Zeiss, A. 1991b: Ein neuer Aspidoceras-Fund aus dem Oberen Jura Norddeutschlands und seine Bedeutung für die Biostratigraphie des norddeutschen Kimmeridge. Osnabrücker naturwissenschaftliche Mitteilungen 17, 87-94.

Zeiss, A. 2001: Die Ammonitenfauna der Tithonklippen von Ernstbrunn, Niederösterreich. Neue Denkschriften des Naturhistorischen Museums in Wien 6, 115 pp.

Zeiss, A. \& Bachmayer, F. 1989: Zum Alter der Enstbrunner Kalke (Tithon; Niederösterreich). Annalen des Naturhistorischen Museums Wien A 90, 103-109.

Zeiss, A., Schweigert, G. \& Scherzinger, A. 1996: Hegovisphinctes, n. gen., eine neue Ammonitengattung aus dem Unter-Tithonium des nördlichen Hegaus und einige Bemerkungen zur Taxonomie des Lithacoceratinae. Geologische Blätter für Nordost-Bayern und angrenzende Gebiete 46, 127-144.

Zhamojda, A.I. 1991: Postanovlenie o polozhenii Kellovejskogo jarusa v obshtshej stratigrafitsheskoj shkale jurskoj sistemy. (Resolution on the position of the Callovian Stage in the entire stratigraphic scale of the Jurassic System.) In: Postanovlenija mezhvedomstvennogo stratigraficheskogo komiteta i ego postojannych komissij (Resolutions of the interdepartmental stratigraphic committee and its permanent commissions). Vypusk 25, 23 only. Leningrad: VSEGEI and IGGD (in Russian).

Ziegler, B. 1964: Das untere Kimmeridgien in Europa. In: Maubeuge, P.L. (ed.): Colloque du Jurassique à Luxembourg 1962, 345-354. Luxembourg: L'Institut Grand-Ducal.

Ziegler, B. 1977: The 'White' (Upper) Jurassic in southern Germany. Stuttgarter Beiträge zur Naturkunde Serie B 26, 79 pp.

Zügel, P. 1997: Discovery of a radiolarian fauna from the Tithonian of the Solnhofen area (Southern Franconian Alb, southern Germany). Paläontologische Zeitschrift 71, 197-209.

Zügel, P., Riegraf, W., Schweigert, G. \& Dietl, G. 1998: Radiolaria from the Nusplingen Lithographic Limestone (Late Kimmeridgian, SW-Germany). Stuttgarter Beiträge zur Naturkunde Serie B 268, 1-43. 